\title{
The mental health consequences of the economic crisis in Europe among the employed, the unemployed, and the non-employed
}

ARTICLE in SOCIAL SCIENCE RESEARCH · AUGUST 2015

Impact Factor: 1.27 · DOI: 10.1016/j.ssresearch.2015.08.003

READS

64

3 AUTHORS:

Veerle Buffel

Ghent University

9 PUBLICATIONS 14 CITATIONS

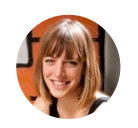

Sarah Van de Velde

University of Antwerp

19 PUBLICATIONS 250 CITATIONS

SEE PROFILE

SEE PROFILE

Piet F. Bracke

Ghent University

106 PUBLICATIONS 1,071 CITATIONS

SEE PROFILE 


\section{Accepted Manuscript}

The mental health consequences of the economic crisis in Europe among the employed, the unemployed, and the non-employed

Veerle Buffel, Sarah Van de Velde, Piet Bracke

PII:

S0049-089X(15)00155-6

DOI:

http://dx.doi.org/10.1016/j.ssresearch.2015.08.003

Reference:

YSSRE 1830

To appear in:

Social Science Research

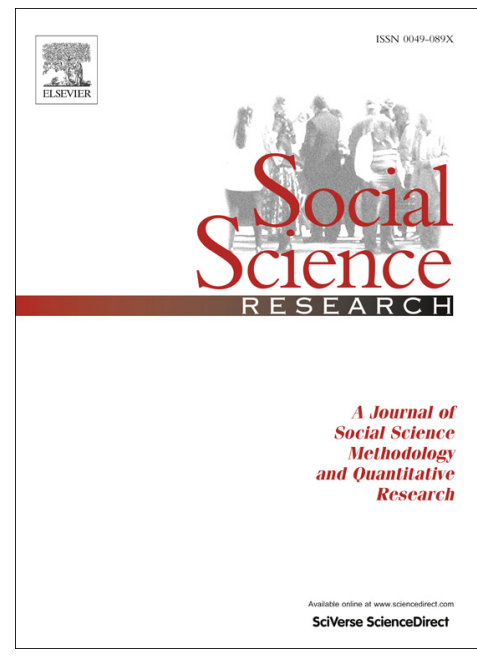

Received Date: 26 March 2014

Revised Date: $\quad 10$ August 2015

Accepted Date: $\quad 21$ August 2015

Please cite this article as: Buffel, V., Velde, S.V.d., Bracke, P., The mental health consequences of the economic crisis in Europe among the employed, the unemployed, and the non-employed, Social Science Research (2015), doi: http://dx.doi.org/10.1016/j.ssresearch.2015.08.003

This is a PDF file of an unedited manuscript that has been accepted for publication. As a service to our customers we are providing this early version of the manuscript. The manuscript will undergo copyediting, typesetting, and review of the resulting proof before it is published in its final form. Please note that during the production process errors may be discovered which could affect the content, and all legal disclaimers that apply to the journal pertain. 


\title{
The mental health consequences of the economic crisis in Europe among the employed, the unemployed, and the non-employed
}

\author{
Buffel, Veerle*; Van de Velde, Sarah* \& Bracke, Piet*
}

*Ghent University; Department of Sociology, Research group HEDERA, Korte Meer 5, 9000 Ghent, Belgium

\section{ABSTRACT}

Applying a multi-level framework to the data from the European Social Survey's Round 3 (2006) and Round 6 (2012), we assessed the crisis by increases in rates of unemployment, while also controlling for countries' pre-crisis economic conditions. We found a positive relationship between depression and an increase in national unemployment rates. This relationship can be only partly ascribed to an increase in the number of unemployed and those employed in nonstandard job conditions - with the exception of the self-employed and women working part-time. The crisis effect is more pronounced among men and those between 35 and 49 years of age. Moreover, in strongly effected countries, the crisis has changed the relationship between part-time work and depression, between depression and certain subcategories of the unemployed (looking for a job or not looking), and between depression and the non-employed. 


\section{INTRODUCTION}

The economic crisis that has affected Europe since 2008, and the related increase in unemployment, worsening of working conditions, and losses of income have raised concerns about the mental health of the population (Mental Health Commission, 2012). As companies seek to reduce labor costs in order to remain afloat, many Europeans have lost their jobs, or experienced cuts in work hours, wages, and other benefits (Eurofound, 2013). Even the previously protected public sector has reacted to economic pressure through an increase in outsourcing and temporary jobs (Benach et al., 2014). Evidence consistently shows that unemployment is associated with an increase in mental health problems (Bartley, 1994; McKee-Ryan, Song, Wanberg, \& Kinicki, 2005; Paul \& Moser, 2009). The fear and insecurity generated by the anticipation of unemployment is also associated with poor mental health — in some cases even more so than actual job loss (Buffel, Dereuddre, \& Bracke, 2015; Benach \& Muntaner, 2007; Burgard, Brand, \& House, 2009). Recent European research has indeed shown sharp increases in unemployment and job insecurity (Eurofound, 2013), as well as in depressive feelings and suicidality (Cooper, 2011).

Within the European context, the current economic crisis has been especially linked to increased mental health problems in Greece (Economou, Madianos, Peppou, Patelakis, \& Stefanis, 2013; Madianos, Economou, Alexiou, \& Stefanis, 2011), Italy (De Vogli, Vieno, \& Lenzi, 2014), Spain (Cordoba-Dona, San Sebastian, Escolar-Pujolar, Martinez-Faure, \& Gustafsson, 2014; Fernandez-Rivas \& Gonzalez-Torres, 2013; Gili, Roca, Basu, McKee, \& Stuckler, 2012; Roca, Gili, Garcia-Campayo, \& Garcia-Toro, 2013), and the UK (Barr, Taylor-Robinson, Scott-Samuel, McKee, \& Stuckler, 2012; Katikireddi, Niedzwiedz, \& Popham, 2012). However, these countries differ significantly from each other, both in terms of economic conditions prior to the start of the crisis and the degree to which they have been affected by the recession. Instead of incorporating actual measurements of economic change due to the crisis, most existing studies were restricted to crude period measurements. For example, these studies compared the prevalence of mental health problems at the start of the economic crisis with their prevalence during the crisis. In addition, by using single-country data, these studies were unable to examine whether there is a mental health effect of the current crisis above and beyond the effect on individuals whose employment status or job conditions changed. It therefore has remained uncertain whether the economic crisis only had an effect on the mental health of individuals who actually lost their jobs, or also on those who 
were already non-employed or unemployed before the crisis, and those who remained employed during the crisis. For example, high unemployment rates might limit workers' bargaining power, while increasing job insecurity or forcing workers to accepting less desirable employment conditions (e.g., part-time and temporary contract work) (Benach et al., 2014).

The few studies that have applied a cross-national perspective and/or examined the distressing effects of macroeconomic conditions were either carried out during a period of normal economic fluctuations (Catalano, Dooley, \& Jackson, 1985; Dooley \& Catalano, 1984; Stuckler, Basu, Suhrcke, \& McKee, 2009) or used aggregated data (Baumbach \& Gulis, 2014). One study by Noelke and Beckfield (2014) did use a dynamic macroeconomic indicator for examining the impact of local labor demand (indicated by unemployment rates) on mortality risks. However, this research was limited to the American population aged 50 years or older.

Using information from the European Social Survey (ESS), a representative data set of the population in almost all European countries, we were able to fill this gap in the literature. In our study, we used data from ESS Round 3 (2006), which was collected before the start of the economic crisis, and from ESS Round 6 (2012), which was collected during the crisis. Both rounds gathered information on depression using a shortened version of an internationally validated and reliable inventory: the Centre for Epidemiologic Depression Scale (CES-D) (Missinne, Vandeviver, Van de Velde, \& Bracke, 2014; Van de Velde, Bracke, Levecque, \& Meuleman, 2010). The data allowed us to explore the extent to which the economic crisis affects depressive feelings among the working-age population. Applying a multi-level framework allowed us to assess the economic crisis by increases in unemployment rates, while also controlling for the economic conditions of the countries at the start of the crisis. While a substantial body of research has focused on health behavior, suicide, and mortality (for an overview see Falagas, Vouloumanou, Mavros, \& Karageorgopoulos, 2009; Modrek, Stuckler, McKee, Cullen, \& Basu, 2013; Stuckler, Basu, Suhrcke, \& McKee, 2009), our current study focused on depressive symptoms. This is because mental health is very sensitive to both macroeconomic and individual changes in unemployment and insecure employment conditions (Benach et al., 2014; Katikireddi et al., 2012; Mattei, Ferrari, Pingani, \& Rigatelli, 2014). To the best of our knowledge, ours is the first study to examine the depressive effects of the economic crisis across a wide range of European countries using a multi-level framework. 


\section{THEORY}

\subsection{How employment status and work conditions are related to depressive symptoms at} the individual level

Research has consistently found that unemployment is associated with increased mental problems (McKee-Ryan et al., 2005; Paul \& Moser, 2009). On the one hand, the selection hypothesis argues that individuals with mental health problems are more likely to be without a job (Arrow, 1996), to remain so for longer periods of time (Stewart, 2001), and/or to have characteristics such as low self-esteem and feelings of helplessness-that make them more vulnerable to both unemployment and poor health (Schmitz, 2011; Schroder, 2013). On the other hand, the causation hypothesis posits that unemployment causes mental health problems because the subsequent loss of income raises the thresholds for both accessing mental health care use and pursuing healthy lifestyles (Schroder, 2013). Unemployment may increase feelings of insecurity, shame, and stress related to the loss of income, time structure (Jahoda, 1981), and status (Janlert \& Hammarstrom, 2009). In addition, having a job can provide a feeling of control, whereas a lack of control-which is often related to unemployment or a passive work situation-is a well-known risk factor for depression (Mirowsky \& Ross, 2003).

While the majority of research on the relationship between employment status and mental health primarily has differentiated between those who are and are not employed (Dooley, 2003; Virtanen, Kivimaki, Vahtera, \& Koskenvuo, 2006), some studies also investigated mental health disparities within both groups. Among the inactive population, preretirement (Doshi, Cen, \& Polsky, 2008) and disability (Morris, Cook, \& Shaper, 1994; Quaade, Engholm, Johansen, \& Moller, 2002) have been associated with higher levels of distress and mortality. In addition, discouraged workers (the unemployed who want a job but are not actively looking for one) may have higher levels of distress than the unemployed who are actively seeking employment (Dooley, 2003).

Within the group of the employed, a number of studies find that nonstandard work, such as (involuntary) part-time jobs (De Moortel, Vandenheede, \& Vanroelen, 2014), temporary employment (Martens, Nijhuis, Van Boxtel, \& Knottnerus, 1999; Virtanen et al., 2005), and employment without a contract (Artazcoz, Benach, Borrell, \& Cortes, 2005) is 
associated with higher levels of distress. The health disparity between standard full-time workers and nonstandard workers is often ascribed to the latter group's higher levels of job insecurity and lack of legal protection (Benach et al., 2000; Benavides, Benach, Diez-Roux, \& Roman, 2000; Virtanen, Kivimaki, Elovainio, Vahtera, \& Ferrie, 2003). There is also evidence that women are disproportionately represented in jobs with nonstandard contracts (Benach, Amable, Muntaner, \& Benavides, 2002). However, not all research confirms the negative mental health effects of temporary work (Artazcoz et al., 2005), part-time work or self-employment (Jamal, 1997; Parslow et al., 2004). When part-time work and selfemployment are strategies to enhance the balance between work and care responsibilities, they may actually improve mental health, especially among women (Jamal, 1997; Parslow et al., 2004). Despite these empirical findings, evidence for the negative mental health effects of nonstandard jobs is still scarce and inconclusive (Benach \& Muntaner, 2007; Keuskamp, Ziersch, Baum, \& LaMontagne, 2013; McKee-Ryan \& Harvey, 2011).

\subsection{The impact of the economic crisis on depressive symptoms through changing employment status and work conditions and/or their relation to depressive symptoms}

The current economic crisis has led to higher unemployment rates, together with higher levels of employment insecurity due to the continued increase in flexibility and non-standardization of the labor market (Benach et al., 2000; Benach et al., 2014b; Benavides et al., 2000; Eurofound, 2013). Additionally, a substantial body of research predicts that mental health problems will increase during an economic crisis. Therefore, changes in the composition of the working-age population should result in an overall increase in mental problems, given that a larger portion of the population is likely to be unemployed or in nonstandard jobs during times of recession.

The negative association between mental health and unemployment or nonemployment may be intensified during times of economic contraction (Blomqvist, Burstrom, \& Backhans, 2014; Paul \& Moser, 2009). Fewer new job opportunities increases competition between job-seekers, while decreasing individual negotiating power (Turner, 1995) and collective bargaining rights (Karamessini \& Rubery, 2013). In several European countriesespecially Southern European countries (Eurofound, 2013)-unemployment and disability benefits have been cut back. This makes the unemployed, and those not employed due to illness or disability, more vulnerable to financial difficulties. In addition, stricter criteria for sickness insurance, -as one of the possible implications of an austerity policy- can lead to 
stronger health selection effects for sickness and disability benefits (Blomqvist et al., 2014). Research has also found that non-employment due to disability or sickness is more strongly related to poor mental health when in a context of economic deprivation, as characterized by a high overall inactivity rate (Fone, Dunstan, Williams, Lloyd, \& Palmer, 2007). However, being unemployed in a context of high total unemployment may be less stigmatizing and less shameful, because the experience is shared (Clark et al., 2010; Clark, 2003). Unemployment may also be less stressful because it can be attributed to external causes (economic recession) rather than to internal ones (personal failure) (Dooley, 2003).

Recession also affects the mental health of people who remain employed, because the unstable labor market increases the extent of job insecurity (Dixon et al., 2013). Employees may be more likely to accept involuntary part-time work or temporary contract work in order to remain employed (Benach et al., 2014a; Karamessini \& Rubery, 2013; Fenwick \& Tausig, 1994). They may also find their work-life balance under greater pressure due to increased job demands and reduced latitude for making decisions (Fenwick \& Tausig 1994). Moreover, austerity measures and implementation of labor market reforms may affect employment conditions, with negative effects on health (Karanikolos et al., 2013). In many countriessuch as Greece, Spain, Ireland, Hungary, Italy, Portugal, and the UK-wages (especially in the public sector) have been frozen or reduced (Bettio, 2012; Rubery \& Rafferty, 2013). In Greece, the minimum wage has been lowered by $20 \%$ (Karanikolos et al., 2013), while social benefits and health care services have been cut back (Bettio, 2012; Karanikolos et al., 2013). During an economic downturn, these mechanisms may attenuate the positive mental health effects of being employed in a standard job (Buffel, Van de Straat, \& Bracke, in press; Wang et al., 2010).

Alternatives to contract employment, such as self-employment or extending education, have also become more prevalent during the current economic crisis. The unstable labor market, and the resulting lack of adequate job opportunities, has encouraged many students to prolong their education (Bell \& Blanchflower, 2011). Conversely, others have been forced into the labor market because of their family's inability to provide financial support (Economou et al., 2013). In the group comprising early-school-leavers, men are overrepresented (Bettio, 2012). Although mental health problems are as prevalent among students as non-students of the same age (Blanco et al., 2008; Hunt \& Eisenberg, 2010), the pressure on and competition between students, combined with pessimistic labor market prospects, may increase their risk of depressive feelings during an economic contraction. Early-school-leavers may actually have a higher likelihood of being unemployed or underemployed (Bell \& 
Blanchflower, 2011), which in turn is related to more depression and anxiety (Paul \& Moser, 2009). Young people have more risk of being marginalized in the labor market because they lack the skills, work experience, and job search abilities required to find employment (ILO, 2006). This makes them more vulnerable to mental health problems and suicide during an economic contraction (Uutela, 2010).

Despite an increased risk of insolvency, the prevalence of self-employment has also risen, most prominently in the countries hit hardest by the recession. Self-employment often acts as a coping mechanism for female workers to address household income loss in a former male-breadwinner model (European Commission, 2010; Karamessini \& Rubery, 2013). In the relevant literature, this is termed the "added worker effect" (Bettio, 2012). This effect can also refer to women who were initially full-time caregivers, but are subsequently forced into the labor market as part-time workers due to economic need. Particularly in Southern Europe, where there is only minimal public childcare support (Artazcoz et al., 2014), working parttime has been related to poor mental health among women (De Moortel, Vandenheede, Muntaner, \& Vanroelen, 2014).

In sum, the main objective of this study was to assess the impact of the economic crisis on depression in Europe by taking countries' pre-crisis economic conditions and the strength of the crisis into account. We investigated the extent to which the expected positive relationship between a high increase in the national unemployment rate (from 2005 to 2011) -as an indicator of the strength of the crisis- and depression, can be ascribed to changes in the composition of the working-age population. We hypothesized that an increase in unemployment (those actively seeking jobs as well as those who want a job but are not actively looking), as well as employment in nonstandard jobs (part-time work and jobs with a temporary contract or no contract), would partly contribute to an increase in the levels of depression in the countries hardest hit by the crisis. Therefore, the individual-level relationships between depression and employment status and conditions were studied. In addition, we examined how these relationships are moderated by the impact of macroeconomic changes resulting from the crisis. We assumed that in countries strongly affected by the recession, the positive relationship between depression and non-employment due to sickness or disability would be stronger, while the negative relationship between depression and employment would be attenuated. We assumed this negative relationship would be particularly attenuated among women who are self-employed or working part-time. Further, being a student may be more related to depressive symptoms during the economic crisis. With regard to the positive relationship between unemployment and depression, two 
contrasting hypotheses can be formulated. On the one hand, a stronger relationship with depression can be expected as the job supply decreases and competition between job-seekers increases; this would particularly be the case those who are still looking for a job. On the other hand, based on the social norm theory and the assumption that health selection effects in unemployment are smaller during recession (Blomqvist et al., 2014), the relationship with depression might be attenuated, as unemployment is more random and perceived more as a structural problem, and because the stigma related to it may be lessened. The analyses are gender-differentiated, as there is overwhelming evidence that employment status and conditions are differently related to depression depending on gender (Artazcoz et al., 2004; Goldman-Mellor, 2010). The recession itself may also have differential effects on men and women (Bettio, 2012; Karamessini \& Rubery, 2013).

\section{METHOD}

\subsection{Data}

The current study used data from Round 3 (2006) and Round 6 (2012) of the European Social Survey (ESS, www.europeansocialsurvey.org), covering more than 20 European countries. The ESS has a repeated cross-sectional survey $\operatorname{design}^{1}$, and both rounds include a comprehensive module on subjective well-being. For each country, the ESS sample was designed following a strict, randomized probability procedure, and data was gathered by means of standardized face-to-face interviews. ESS information is representative for the general population aged 15 years and older living in private households, irrespective of their language, citizenship, and nationality.

We only used information on countries that were included in both rounds, resulting in a sample comprising of 34,953 men and 40,280 women across 20 countries. From this sample, we selected the subsample of the working-age population (20-65 years of age), giving us a sample of 25,765 men and 28,932 women. None of the variables, except the income measurement and the CES-D 8 scale (see below), contained more than $2 \%$ missing values. For men, $1.6 \%$ of the information on employment status was missing; for women, $1.8 \%$ was missing. Spain had the highest percentage of missing information on employment status $(9.1 \%$ in men and $9.8 \%$ in women). The accumulated percentage of missing values for

\footnotetext{
${ }^{1}$ A repeated cross-sectional design means that the survey is carried out more than once over time, but each time with other respondents. The survey is also performed each time in the same way, with largely the same questions and representative of the same population.
} 
the total sample was 5.5\%. These percentages are relatively low, which allowed us to omit these cases from the sample. As a result, the final sample contained information on 24,343 men and 27,336 women.

\subsection{Measures}

Depressive feelings were measured using an eight-item version of the Center for Epidemiologic Studies-Depression Scale (CES-D). The CES-D 8 is constructed to identify populations at risk for developing depressive disorders (Radloff, 1977). It is not meant to be used as a clinical diagnostic tool by itself. Respondents were asked to indicate how often in the week before the survey they felt or behaved in a certain way (e.g., felt depressed, slept badly). Response categories range from 1 (none or almost none of the time) to 4 (all or almost or all of the time). Scale scores are assessed using non-weighted, summated rating and ranged from 0 to 24, with higher scores indicating a greater frequency and severity of depressive complaints. If four or fewer items were missing, mean substitution was applied. The reliability of the scale was good (Cronbach's alpha for men $=.802$, and for women $=.834$ ).

For the independent variable, employment status, we relied on the question "Which of these descriptions best describes your situation (in the last seven days)?" with nine answer categories: (1) in paid work (or away temporarily) (employee, self-employed, working for your family business), (2) in education, (not paid for by employer), (3) unemployed and actively looking for a job, (4) unemployed, wanting a job but not actively looking for a job, (5) (permanently) sick or disabled, (6) retired, (7) in community or military service, (8) doing housework, looking after children or other persons, and (9) other answer possibilities. For the construction of our categorical variable employment status, we reduced the categories to three broad groups: the unemployed (3 and 4); the non-employed (2, 5, 6, and 8) and the employed (1). Within each broad category, we made a further distinction by using conditional factors (Mirowsky, 1999), given that these variables were only applicable to one category of the main variable of employment status. Based on the argument of Dooley and colleagues (Dooley, 2003; Dooley, Prause \& Ham-Rowbottom, 2000), our broad category of the unemployed consisted of both, the respondents answering with answer 3 or 4. Dooley (2003) has argued that the strict definition of unemployment based on the ILO conventions and the Bureau of Labor Statistics (1994) - i.e., unemployed and actively looking for a job (answer 3) - is an underestimation of the unemployed, and perhaps also of the negative relationship with mental health. This is because the definition does not include those without work who want a job, but 
are not or no longer actively looking (answer 4), The latter are also defined as discouraged workers, and are often even more distressed than the "official unemployed" (Dooley, 2003). However, by using the conditional dummy variable for the unemployed-(0) not looking for a job and (1) looking for a job-we were still able to distinguish between the "official unemployed" as defined by the ILO and discouraged workers (those who are not actively looking for a job but still want one). In the category of the non-employed ${ }^{2}$, a distinction is made between (early) retirees (reference category), students, homemakers, and those unable to work due to illness or disability. With regard to the employed, we included two conditional factors: working hours and type of contract. Both factors can be used to differentiate between standard and nonstandard work. In relevant literature, the latter is also sometimes referred to as flexible work, contingent work, or precarious work (Benach et al., 2000; Benach \& Muntaner, 2007). With regard to working hours, we distinguished between full-time employment (more than 34 hours per week), marginal part-time employment (up to 19 hours per week), and substantial part-time employment (20 to 34 hours per week) (Bielenski, Bosch, \& Wagner, 2002; Eurofound, 2007). Full-time employment is used as the reference category, as it is characteristic of standard employment. Type of contract is a categorical variable with four options: unlimited contract, limited contract, no contract, and self-employed. Unlimited contract (or permanent employment) was used as the reference category, because it is again characteristic of standard employment. Limited contract refers to temporary workers, who can be considered as having job insecurity (Benach et al., 2014b). No contract refers to informal work, which is mostly characterized by minimal social protection (Benach et al., 2014b).

The change in national unemployment rate between the pre-crisis period (2005) and the period during the crisis (2011) was taken as the main indicator of the impact of the crisis (Eurofound, 2013; Stuckler, Basu, Suhrcke, Coutts, \& McKee, 2009). It is a relevant measurement to capture the economic turmoil and insecurity faced by the population during periods of economic instability, and it is closely reflects the everyday experience of individuals (Stuckler et al., 2009). In addition, we controlled for the change in Gross Domestic Product (GDP) per individual from 2005 to 2011 (Dooley et al., 2000; Eurofound, 2013). We used data for the year before the interview in order to account for lagged effects of

\footnotetext{
${ }^{2}$ We use the term "non-employed" instead of inactive population, as the inactive population is defined by the ILO as the population of working age persons who are out of labor market force, and also includes "discouraged workers." We have categorized the latter in the unemployed group.
} 
the economic crisis on distress-related outcomes (Tausig \& Fenwick, 1999). This also produces the best model fit. ${ }^{3}$

In addition to using these change variables to estimate longitudinal or change effects (see further explanation in the statistical method section), we also took into account the economic state of each country before the crisis (i.e., the context variables) by using the 2005 national unemployment rates and GDP per individual. Using those two indicators is one of the most generic ways to describe the state of a country's economy, as they reliably reflect economic and labor market conditions (Eurofound, 2013). To calculate these contextual and change variables, we used external data from Eurostat (Labor Force Survey, 2014). ${ }^{4}$ The macroeconomic indicators per country and period are shown in Appendix 1.

We believed it was also important to take into account the period of the survey when examining depression. Period is a categorical variable: 2006 and 2012, with 2006 used as the reference category. By including the period variable in the models, we could partially control for time trends, such as normal economic cycles and changes to health, social, and labor market policies (Buffel, Van de Straat, \& Bracke, 2015). In addition, by using 2006 as the reference period, we were able to compare the situation during the economic crisis (2012) with the situation in the most recent period before it started (2006).

We selected individual control variables known to be associated with depression: demographic (age and marital status) and socioeconomic characteristics (educational level and household income). Age is included as a categorical variable: 20-34, 35-49 (reference category), and 50-65 years of age. Marital status was assessed by distinguishing married (reference category) from divorced, widowed, and never married respondents. We measured the educational level of the respondents by their total number of years in full-time education. Respondents who reported a number of years that was three standard deviations from the country mean were considered outliers and removed from our sample. To account for nonlinear effects of education on depression, a squared term for education is also included. The income level of respondents was assessed by relative equivalent household income, using the Modified OECD quivalence scale (OECD, 2005). In this way, we could also partly take into account the partner's employment status. To account for the high number of item nonresponses, relative equivalent income was coded into five categories, with one category representing respondents with missing income data. The other categories represent the low $(<$

\footnotetext{
3 The correlation between both measurements was not greater than $r=0.4$. We also controlled for multicollinearity.

${ }^{4}$ For information on countries or years which are not available from Eurostat, we relied on OECD data.
} 
$50 \%$ of the median equivalent income), moderate $(50 \%-79 \%$ of the median), high $(80 \%-$ $119 \%$ of the median; reference category), and highest income groups $(\geq 120 \%$ of the median). ${ }^{5}$

\subsection{Statistical methods}

We used two Rounds (3 and 6) of the ESS, which has a repeated cross-sectional design and contains information about depression. Both rounds included information on roughly 20 European countries. We specified our multi-level model by considering the individuals (level 1) nested in country years (level 2). These were, in turn, nested in countries (level 3) (see Figure 1). In contrast to conventional or cross-classified multi-level modeling, which only allows for the inclusion of a uniform period effect across all countries, this modeling had two advantages. First, it allowed us to control for specific national trends in the effect of the economic crisis. As not every country was affected by, or responded to the crisis in the same way (Stuckler et al. 2009), we assumed that the periodic changes-from pre-crisis (2006) to crisis period (2012) — in the unemployment rate and GDP were distinct for each country. Thus, by nesting specific period effects for each country at level 2 and the country effect at level 3, we could take into account the specific national economic conditions prior to the start of the crisis, and the degree to which each country was affected by the recession. This modeling allowed us to estimate the specific effect of someone living in, say, Belgium, versus someone living in Spain in 2006 and 2012. Thus, we were able to take into account the very different economic conditions of both countries at the start of the crisis, as well as the way in which both countries responded to the economic crisis. Second, the manner of modeling allowed us to attain an adequate number of higher-level units. Since the ESS collected information regarding depressive symptoms in only two rounds, we did not have a large enough number of units to include the period effect as a separate level of analysis (Stegmueller 2013). In line with Fairbrother (2014), we considered the clustering of individuals within periods ( 2 rounds: 2006 and 2012) clustered within countries (20 countries participating in both rounds), thereby attaining sufficient power at level 2 ( $n=2$ years $\mathrm{x} 20$ countries $=40$ ). The advantage of such national-level time-series cross-sectional data is that we were able to simultaneously model the cross-sectional effect, which explains differences

\footnotetext{
${ }^{5}$ With regard to depression, the category of respondents with missing data on income did not significantly differ from the reference category: those with a high income.
} 
between countries, and longitudinal effects, which explain differences within countries over time (Fairbrother, 2014; Van der Bracht \& Van de Putte, 2014). Applied to our model, this meant our main change variable, measured as the difference between national unemployment rate before the crisis (2006) and during the crisis (2012), was introduced in the model at this period level per country-year, while national pre-crisis unemployment rate was located at the highest level, the country level. The time dimension was, therefore, located at level 2, the period level.

In sum, as can be seen in Figure 1, respondents, as units at the individual level (level 1: $N$ men $=24,343 ; N$ women $=27,336$ ), were nested within survey years ranging from 2006 to 2012 at the period level (level 2). This was, in turn, nested within countries (level 3). As result, we had a multi-level design of 40 different country years at period level 2, and 20 countries at country level 3. Figure 1 also specifies the different variables that are included in the models, per level. The change effects of the unemployment rate and the GDP (the difference between 2005 and 2011 per country) were included in the model at the periodcountry level, while in the same model, the cross-sectional effects of unemployment rate and GDP (data of 2005) were at the country level. In this way, the longitudinal effects of the change indicators were orthogonal to the cross-sectional effects (Fairbrother, 2014; Van der Bracht \& Van de Putte, 2014). Recently, this method has proven its additional value in two other studies (Buffel, van de Straat, \& Bracke 2015, Van der Bracht \& Van de Putte, 2014). 
Figure 1: Presentation of the three-level model, with the number of units and the variables per level

\begin{tabular}{|c|}
\hline $\begin{array}{l}\text { 3. Country level: } 20 \text { countries } \\
\text { Cross sectional or structural effects } \\
\text { - Unemployment rate } \\
\text { - GDP per inhabitant }\end{array}$ \\
\hline$\uparrow$ \\
\hline 2. Period level: Period $(2006,2012) \mathrm{x}$ country \\
\hline$=40$ country years \\
\hline Longitudinal or change effects \\
\hline $\begin{array}{l}\text { - Change in unemployment rate } \\
\text { - Change in GDP } \\
\text { - Period variable }\end{array}$ \\
\hline$\uparrow$ \\
\hline 1. Individual level: \\
\hline $\mathrm{N}$ men $=24,343$ \\
\hline $\mathrm{N}$ women $=27,336$ \\
\hline $\begin{array}{l}\text { - Depressive feelings } \\
\text { - Employment status \& conditional factors } \\
\text { - Age, education, education', marital status, \& } \\
\text { equivalent household income }\end{array}$ \\
\hline
\end{tabular}

Our analyses comprised two parts. First, we will discuss some descriptive results, presented in Table 1 and Table 2. The first table shows the mean score on the depression scale by employment status and conditions within each main employment status category. Table 2 presents the mean scores on depression and the composition of the population of working age in our sample per period, gender, and countries - with the latter grouped according to the strength of the impact of the economic crisis, based on the categorization by Eurofound (2013).

Second, the impact of the crisis was assessed by analyzing the effect of the change in unemployment rate on depressive feelings, using a three-level model (see above). The first model included the change variables-change in the unemployment rate and GDP between 2005 and 2011-while controlling for the period variable, macroeconomic context variables (the unemployment rate and GDP for 2005), and individual control variables (marital status, age, education, education ${ }^{2}$, and equivalent household income). In the second model, we added individual employment status to assess the extent to which the possible relationship between 
economic contraction (as indicated by a strong increase in the unemployment rate) and depression could be ascribed to a composition effect of employment status. In the third model, the conditional factors of employment status were also included, to explore whether, and to what extent, they further explain the possible relationship between depression and change in the unemployment rate. Last model used cross-level interactions with change in the unemployment rate to assess whether some employment status conditions are differently related to depression according to an increase in the unemployment rate. If the interaction effects were not significant, they were excluded from the analysis; this enhanced interpretability and provided a more parsimonious model.

The conditional factors of job-seeking or not job-seeking for the unemployed, the different types of non-employment, and working hours, and type of contract for the employed were all included in the models using internal interaction effects as proposed by Mirowsy and Ross (Mirowsky, 1999). Internal interaction effects can only be carried out when the corresponding main category of the employment status variable is not used in the models as the reference category. Therefore, in Table 3 the unemployed were used as the reference category, and the conditional factors of the employed were included in the models. Likewise, in Table 4, the employed are the reference category, and the conditional factors of the unemployed and the non-employed were added to the models.

The number of countries at the highest level is quite small $(\mathrm{N}=20)$. While there is no consistent rule about the required number of cases, the reliability of estimates depends on several factors, such as the number of country variables, random components and cross level interactions (Stegmueller, 2013; Bryan and Jenkins 2013). Therefore, no cross-level interactions are included at the country level. In addition, the change variable, operationalized by multiplying country by period consists of 40 units. In line with Bryan and Jenkins, (2013); and Stegmueller (2013) we additionally applied a Bayesian approach to handle with the small number of higher level units. Therefore, all the models were estimated with the statistical software package MLwiN using Markov Chain Monte Carlo (MCMC) estimation procedures, this approach has been proven to be far more robust when also including cross-level interactions (Stegmueller, 2013).

\section{RESULTS}

The descriptive results presented in Table 1 show that, in general, the unemployed $\left(\overline{\mathrm{x}}_{\mathrm{men}}=\right.$ $7.015 ; \overline{\mathrm{x}}_{\text {women }}=7.353$ ) had the highest score on the depression scale, followed by the non- 
employed $(\overline{\mathrm{x}}=6.170 ; \overline{\mathrm{x}}=6.466)$, and then the employed $(\overline{\mathrm{x}}=4.697 ; \overline{\mathrm{x}}=5.407)$. This pattern is the same for men and women, although some gendered differences occured within the subcategories. In the group comprising employed women, the self-employed $(\overline{\mathrm{x}}=5.260)$ and the employed working part-time $\left(\overline{\mathrm{x}}_{\text {subst. part-time }}=5.308 ; \overline{\mathrm{x}}_{\text {marg. }}\right.$ part-time $\left.=5.330\right)$ had the lowest depression scores; among men, those with standard working employment conditionsunlimited contract $(\overline{\mathrm{x}}=4.591)$ and full-time work $(\overline{\mathrm{x}}=4.682)$ - had the lowest depression scores. Unemployed men not actively seeking a job $(\overline{\mathrm{x}}=7.572)$ had a substantially higher score on the depression scale than unemployed looking for work $(\overline{\mathrm{x}}=6.813)$, while among unemployed women the difference was smaller $\left(\overline{\mathrm{x}}_{\text {not seeking }}=7.527 ; \overline{\mathrm{x}}_{\text {seeking }}=7.282\right)$. Employed women with limited contracts $(\overline{\mathrm{x}}=5.853)$ had a similar depression score to that of homemakers $(\bar{x}=5.989)$, which was not the case for men $(\bar{x}=5.315$ and $\bar{x}=5.905$, respectively). Homemaking men had more depressive symptoms than those employed under any conditions.

Table 1: Depression scores by employment status and their conditional factors, separately for men and women

Depression (CES-D 8: 0-24)

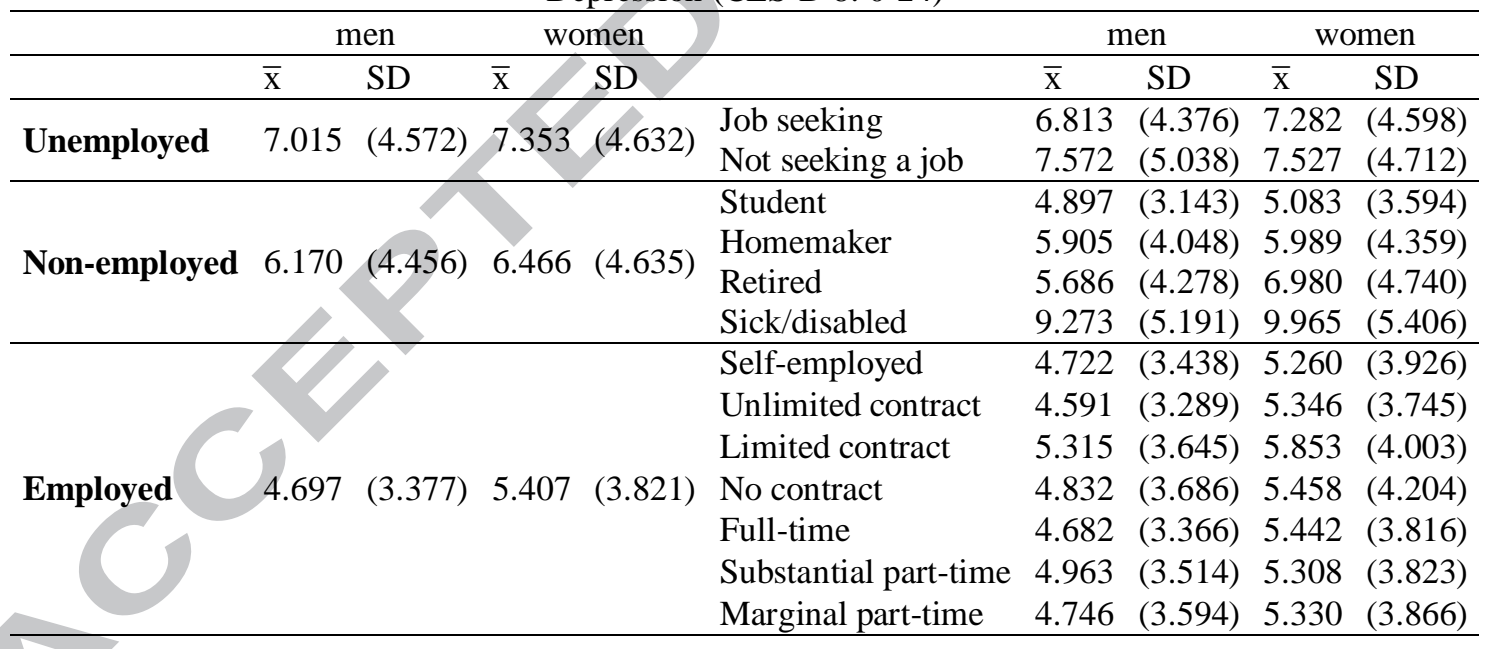

For the descriptive results presented in Table 2, we relied on the Eurofound (2013) classification of European countries by the size of the effect of the crisis. This classification is based on changes in the unemployment rate and the GDP growth rate. ${ }^{6}$ In general, the levels of depression in Europe decreased from 2006 to 2012. There was only an increase in depressive symptoms in the categories strong and stronger affected countries by the crisis. For women, this only applied to the latter category of countries. Examining the country-specific

\footnotetext{
${ }^{6}$ Countries not included in this classification were assigned to a category based on the same indicators.
} 
results (not shown in the table), a significant increase in depression from 2006 to 2012 was observed, especially in Spain $(p<.001)$ and Cyprus $(p<.01)$.

In all categories, except for countries in the "weaker" affected category, there was an increase in unemployment, which was reflected by a greater increase in the group of unemployed actively seeking work. The increase in unemployment was only slightly more pronounced among men than women. However, there was a significant increase in nonemployment among men. In particular, the number of students, retired, and sick or disabled men increased in the last two country categories. By contrast, there was a decreased trend in non-employment for women, which can be especially ascribed to the number of homemakers. The decrease in the number of employed for both men and women was concentrated among those employed full time. With regard to type of contract employees, this trend was concentrated in those with nonstandard job conditions (those employed with a limited contract or no contract). 
Table 2: Descriptives for the variables depression and employment status by period (2006, 2012), gender, and category of countries classified by Eurofound (2013) according to the impact of the crisis

\begin{tabular}{|c|c|c|c|c|c|c|c|c|c|c|c|c|c|c|c|c|c|c|c|c|c|c|}
\hline & \multirow[t]{2}{*}{ Effect of crisis } & \multicolumn{3}{|c|}{ Weaker } & \multicolumn{3}{|c|}{ Weak } & \multicolumn{3}{|c|}{ Fairly weak } & \multicolumn{3}{|c|}{ Average } & \multicolumn{3}{|c|}{ Fairly strong } & \multicolumn{3}{|c|}{ Strong } & \multicolumn{3}{|c|}{ Stronger } \\
\hline & & 2006 & 2012 & & 2006 & 2012 & & 2006 & 2012 & & 2006 & 2012 & & 2006 & 2012 & & 2006 & 2012 & & 2006 & 2012 & \\
\hline & $\begin{array}{l}\text { Depression }(\overline{\mathrm{x}}) \\
\text { Employment status }\left(\%^{\mathrm{a}}\right)\end{array}$ & 5.4 & 4.8 & $* * *$ & 5.0 & 4.7 & $* *$ & 4.8 & 4.8 & & 5.2 & 5.0 & & 5.7 & 5.4 & & 6.0 & 6.2 & $*$ & 4.7 & 5.1 & $* *$ \\
\hline & Unemployed & 8.0 & 6.4 & $*$ & 5.5 & 6.4 & & 6.0 & 7.4 & & 9.1 & 13.3 & $* *$ & 6.0 & 10.4 & $* * *$ & 5.5 & 13.6 & $* * *$ & 6.2 & 23.2 & $* * *$ \\
\hline & Job seeking (\% yes) & 5.2 & 4.5 & & 3.9 & 4.8 & & 3.8 & 6.0 & $* *$ & 6.3 & 4.6 & & 3.8 & 8.2 & $* *$ & 3.8 & 10.6 & $* * *$ & 4.4 & 18.8 & $* * *$ \\
\hline & Non-employed & 17.0 & 18.0 & & 14.8 & 17.2 & * & 18.0 & 19.7 & $*$ & 17.3 & 18.0 & & 21.6 & 22.0 & $*$ & 16.6 & 18.7 & $* *$ & 12.5 & 19.1 & $* * *$ \\
\hline & Student & 4.5 & 5.6 & & 5.0 & 5.7 & & 2.1 & 3.4 & * & 4.1 & 3.6 & & 4.0 & 7.2 & $* * *$ & 5.5 & 5.6 & & 3.3 & 6.9 & $* *$ \\
\hline & Homemaker & 1.4 & 1.0 & & 1.8 & 1.5 & & 2.5 & 1.6 & * & 0.9 & 2.2 & $* *$ & 2.1 & 2.2 & & 0.3 & 0.8 & & 1.0 & 1.2 & \\
\hline & Retired & 8.8 & 9.2 & & 5.0 & 6.1 & * & 9.5 & 8.7 & * & 10.1 & 10.1 & & 10.3 & 9.2 & 8 & 8.3 & 9.5 & * & 4.4 & 6.4 & * \\
\hline & Sick/disabled & 2.2 & 2.2 & & 3.1 & 4.0 & & 3.9 & 5.9 & * & 2.2 & 2.2 & & 5.2 & 3.5 & $* * *$ & 2.4 & 2.8 & & 3.9 & 4.6 & * \\
\hline \multirow[t]{17}{*}{ Men } & $\begin{array}{l}\text { Employed } \\
\text { Type of contract }\end{array}$ & 75.1 & 75.6 & & 79.7 & 76.4 & $* *$ & 76.0 & 72.9 & * & 73.6 & 68.7 & $* *$ & 72.5 & 67.6 & $* * *$ & 77.9 & 67.8 & $* * * *$ & 81.3 & 57.8 & $* * *$ \\
\hline & Self-employed & 14.6 & 12.1 & $* *$ & 12.3 & 15.0 & & 9.4 & 11.4 & * & 13.1 & 12.8 & & 10.8 & 11.2 & & 11.7 & 10.4 & & 20.8 & 14.2 & $* * *$ \\
\hline & Unlimited contract & 51.2 & 53.3 & * & 59.0 & 58.2 & & 56.2 & 53.1 & & 42.6 & 43.9 & & 50.6 & 48.0 & & 52.3 & 49.3 & * & 39.8 & 30.9 & $* * *$ \\
\hline & Limited contract & 8.2 & 9.1 & & 6.6 & 5.0 & & 8.5 & 7.8 & $* *$ & 8.5 & 6.6 & $* *$ & 6.2 & 6.3 & $* * *$ & 9.5 & 6.1 & * & 11.2 & 7.0 & $*$ \\
\hline & No contract & 1.0 & 1.2 & & 1.9 & 1.8 & & 1.8 & 0.7 & $*$ & 9.5 & 5.5 & $* *$ & 4.9 & 2.2 & * & 4.5 & 2.0 & * & 9.5 & 5.6 & * \\
\hline & Working hours & & & & & & & & & & & & & & & & & & & & & \\
\hline & Full-time & 70.9 & 71.3 & & 74.9 & 71.5 & & 67.4 & 63.6 & & 67.4 & 63.6 & 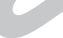 & 69.8 & 64.8 & & 69.1 & 64.0 & ** & 76.2 & 64.1 & ** \\
\hline & Substantial part-time & 3.2 & 3.2 & & 4.0 & 3.8 & & 6.9 & 7.4 & & 6.9 & 7.4 & & 3.6 & 3.1 & & 2.5 & 2.4 & & 1.6 & 1.7 & $* *$ \\
\hline & Marginal part-time & 1.0 & 1.1 & & 0.7 & 1.1 & & 1.7 & 2.0 & & 1.7 & 2.0 & $*$ & 0.2 & 0.8 & & 0.9 & 1.3 & $* * *$ & 0.1 & 2.0 & $*$ \\
\hline & $\begin{array}{l}\text { Depression }(\overline{\mathrm{x}}) \\
\text { Employment status }\left(\%^{\mathrm{a}}\right)\end{array}$ & 6.0 & 5.8 & & 5.7 & 5.4 & $*$ & 5.8 & 5.7 & & 6.1 & 5.9 & & 6.3 & 6.0 & $*$ & 7.3 & 6.3 & $* * *$ & 5.1 & 5.9 & *** \\
\hline & Unemployed & 6.6 & 5.6 & & 5.8 & 7.4 & * & 6.1 & 7.8 & * & 8.1 & 10.5 & $* *$ & 4.1 & 7.5 & $* * * *$ & 7.0 & 13.0 & $* * * *$ & 4.2 & 14.1 & $* * *$ \\
\hline & Job seeking (\% yes) & 4.8 & 4.1 & & 3.9 & 5.2 & & 4.4 & 5.6 & & 4.8 & 8.2 & $* * *$ & 2.8 & 5.0 & & 4.1 & 10.0 & $* * *$ & 2.8 & 10.7 & \\
\hline & Non-employed & 39.4 & 35.0 & **** & 27.2 & 28.3 & & 35.1 & 32.5 & & 34.4 & 31.0 & * & 37.5 & 33.2 & $* * *$ & 29.1 & 28.4 & & 41.9 & 38.9 & * \\
\hline & Student & 4.6 & 4.8 & & 5.5 & 5.7 & & 3.5 & 4.2 & 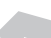 & 4.3 & 5.2 & & 5.6 & 6.4 & $* *$ & 4.4 & 5.2 & * & 3.6 & 6.4 & $* * *$ \\
\hline & Homemaker & 23.7 & 19.3 & * & 20.5 & 13.9 & $* * *$ & 20.5 & 13.9 & $* * *$ & 17.7 & 22.7 & & 15.7 & 12.8 & * & 12.8 & 11.3 & * & 34.5 & 27.2 & $* * *$ \\
\hline & Retired & 9.4 & 9.1 & & 3.6 & 7.9 & $* * *$ & 3.6 & 7.9 & ** & 10.2 & 10.7 & & 12.4 & 10.8 & & 9.3 & 9.0 & & 2.0 & 3.2 & $* *$ \\
\hline & Sick/disabled & 1.6 & 1.9 & & 3.7 & 4.4 & & 4.8 & 6.6 & ** & 2.2 & 2.4 & & 3.7 & 3.2 & & 2.6 & 3.0 & & 1.8 & 2.1 & \\
\hline \multirow[t]{9}{*}{ Women } & Employed & 53.9 & 59.3 & $* * *$ & 67.0 & 64.3 & $*$ & 58.8 & 59.7 & & 57.5 & 58.4 & & 58.4 & 59.3 & & 63.9 & 58.5 & $* * *$ & 53.9 & 47.1 & $* * *$ \\
\hline & $\begin{array}{l}\text { Type of contract } \\
\text { Self-employed }\end{array}$ & 6.6 & 6.8 & & 5.2 & 4.9 & & 3.6 & 4.7 & & 4.9 & 5.7 & & 3.5 & 4.2 & & 6.6 & 5.8 & & 5.9 & 5.1 & \\
\hline & Unlimited contract & 39.3 & 44.0 & & 52.4 & 51.9 & & 45.8 & 45.1 & & 36.1 & 40.3 & & 45.7 & 46.4 & & 45.0 & 46.2 & $* * *$ & 30.2 & 28.3 & * \\
\hline & Limited contract & 6.5 & 7.5 & & 8.2 & 6.4 & & 7.3 & 8.6 & $* *$ & 9.5 & 8.1 & * & 6.4 & 6.6 & & 9.1 & 4.1 & * & 10.8 & 7.2 & \\
\hline & No contract & 1.4 & 1.1 & & 1.2 & 1.0 & & 2.2 & 1.2 & & 7.0 & 4.5 & $* *$ & 2.8 & 2.1 & * & 3.3 & 2.4 & $* *$ & 7.0 & 6.4 & \\
\hline & Working hours & & & & & & & & & & & & & & & & & & & & & \\
\hline & Full-time & 34.7 & 39.1 & & 48.2 & 50.0 & & 31.1 & 32.9 & & 50.0 & 50.6 & & 42.9 & 43.5 & & 57.6 & 51.7 & & 39.5 & 28.9 & $* * *$ \\
\hline & Substantial part-time & 14.0 & 15.1 & & 14.8 & 11.3 & **** & 20.8 & 20.6 & & 6.4 & 6.7 & & 11.7 & 11.7 & & 5.4 & 4.2 & & 10.3 & 13.3 & $* * *$ \\
\hline & Marginal part-time & 5.2 & 5.2 & & 4.0 & 3.1 & & 6.9 & 6.2 & & 1.1 & 1.1 & & 3.8 & 4.1 & & 0.9 & 2.6 & $* * *$ & 4.0 & 4.8 & * \\
\hline
\end{tabular}

Anova-test for the metric variable depression and pairs-wise Chi²-test for the categorical variables to assess whether the differences between 2006 and 2012 are significant; $* p<.050 * * p<.010 * * * p<.001$ (two-sided).

Weaker = Germany, Poland, Switzerland; Weak = Norway, Sweden, Belgium, Slovakia; Fairly weak = Netherlands, France; Average = Finland, Bulgaria, Cyprus; Fairly strong = UK, Denmark, Slovenia, Hungary; Strong = Portugal, Estonia; Stronger $=$ Spain, Ireland. 
In Table 3, the impact of the strength of the crisis is assessed by analyzing the effect of change in the unemployment rate on depressive feelings. In the first model, the period effect shows that in $2012\left(b_{\text {men }}=-0.511[0.095] ; b_{\text {women }}=-0.560[0.136]\right)$ the likelihood of being depressed was significantly lower than in 2006, which is also observed in the descriptive results. There was also a context effect: in countries with a high GDP per inhabitant pre-crisis $(2005)$, both men $(b=-0.050[0.013])$ and women $(b$ $=-0.054[0.012])$ were less likely to be depressed than men and women in countries with a lower GDP. With regard to the crisis effect, we found a positive relationship between depressive feelings and change in the rate of unemployment. In countries with a high increase in the unemployment rate from 2005 to 2011 , women ( $b=$ $0.047[0.019])$ and especially men $(b=0.053[0.013])$ had a higher likelihood of being depressed, controlling for period, household income, age, education, marital status, and the country's economic conditions before the crisis. We carried out the analyses once with men and women together. Via an interaction effect with gender and change in unemployment, we found that the crisis effect was significantly stronger among men (after also controlling for individual employment status). This positive effect of an increase in unemployment on depression was also significantly more pronounced for the middle-age category (35-49 years). (For the results of the analysis with men and women pooled, see Appendix 2.)

When we took individual employment status into account in Model 2, the relationship between depression and change in the unemployment rate attenuated, but remained significant for both men $(b=0.039[0.013])$ and women $(b=0.041[0.020])$. Especially among men, the crisis effect can partly be ascribed to the increase in the number of unemployed or non-employed men. In the descriptive results, we found a large increase in the number of unemployed and non-employed men in countries strongly affected by the crisis (Table 2), and these categories had a higher mean score on the depression scale (see Table 1). 
Table 3: Depression regressed on change in unemployment rate, individual employment status, and different work conditions

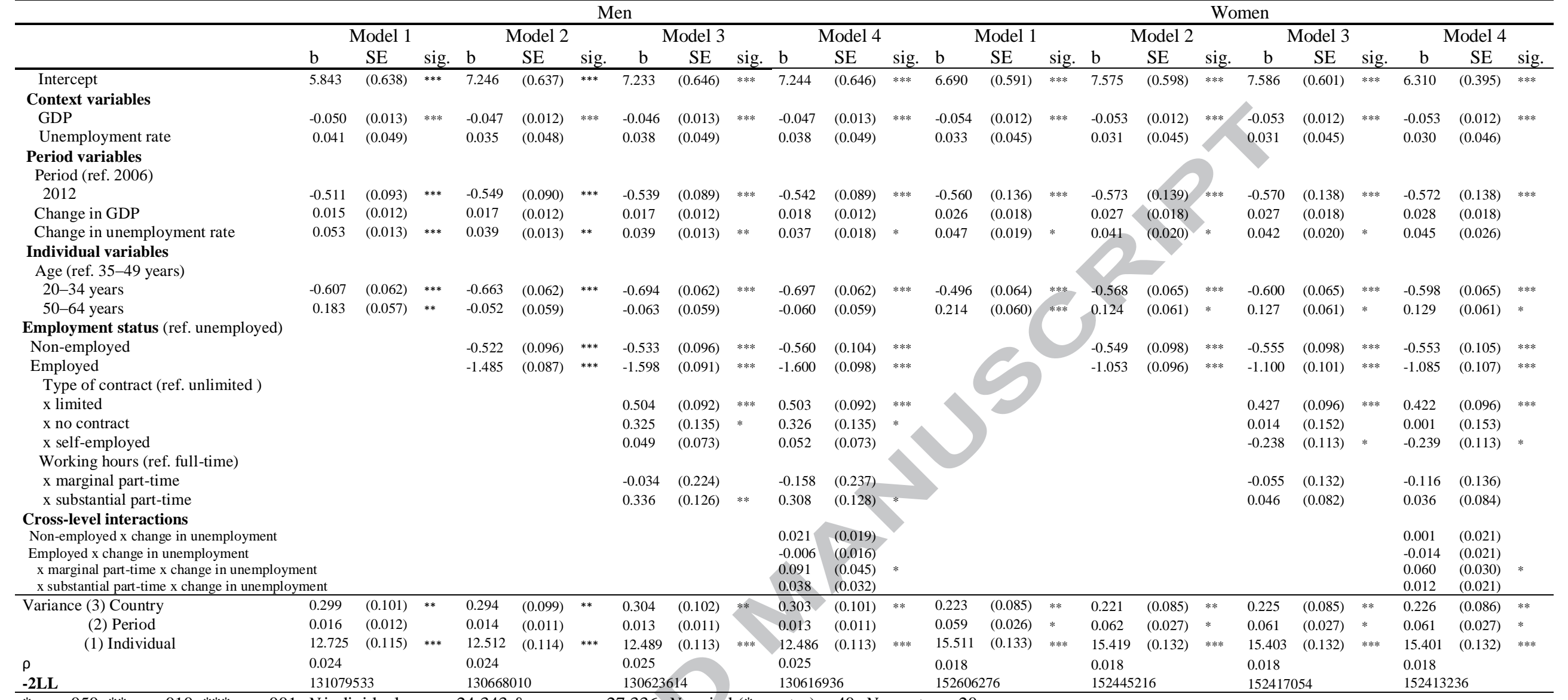

$* p<.050 * * p<.010 * * * p<.001 ; N$ individual men $=24,343 \&$ women $=27,336 ; N$ period $(*$ country $)=40 ; N$ country $=20$.

All models controlled for education, education ${ }^{2}$, marital status and income.

$\rho$ Variance at both higher levels: 3 and $2($ country + period $)=\left(\sigma_{\text {country }}^{2}+\sigma_{\text {period }}^{2}\right) /\left(\sigma_{\text {country }}^{2}+\sigma_{\text {period }}^{2}+\sigma_{\text {individual }}^{2}\right)$. 
In Model 3, the conditional factors of the employed were added via internal interaction effects. We did not find a composition effect from the type of contract and working hours, as the effect of change in the unemployment rate on depression did not really vary between men $(b=0.039[0.013])$ and women $(b=0.042[0.020])$. Employed men and women with a limited contract $\left(b_{\text {men }}=0.504[0.092] ; b_{\text {women }}=0.427[0.092]\right)$ and employed men with no contract $(b=$ $0.325[0.135]$ ) have a higher likelihood of reporting depressive symptoms compared with the employed with an unlimited contract.

Only self-employed women $(b=-0.238[0.113])$ were less likely to be depressed when compared with the employed with standard job conditions (unlimited contract and full-time). With regard to working hours, there was only a significant relationship with depression among men; men who worked substantially part-time $(b=0.336[0.126])$ were more likely to be depressed than employed men with standard job conditions.

In Model 4, a significant cross-level interaction among the employed men and women was found between working hours and the crisis effect. Although the main effect of being a marginal part-time worker (compared with a full-time worker) on depression was not significant, we found that in countries with a high increase in unemployment, marginal parttime working men $(b=0.091[0.045])$ and women $(b=0.060[0.030])$ were more likely to be depressed than if there had been no increase or a decrease in a country's unemployment rate.

In Table 4, the unemployed and non-employed were compared with the employed. The unemployed $\left(b_{\text {men }}=1.485[0.087] ; b_{\text {women }}=1.053[0.096]\right)$ and the non-employed $(b=$ $0.963[0.065] ; \mathrm{b}=0.504[0.056])$ were more likely to be depressed than the employed, and both differences were more pronounced among men (Model 1).

In Model 2, after taking the conditional factors of the unemployed and non-employed into account, the effect of change in the unemployment rate on depression for both men and women was almost unaltered, and even rose slightly $\left(b_{\text {men }}=0.039\right.$ [0.013] Model 1 to $b=$ $0.041[0.013]$ Model 2; $b_{\text {women }}=0.041[0.020]$ to $b=0.044[0.019]$ ). Only among the male unemployed was there a difference in depression depending on whether or not the individual was actively seeking a job. In particular, discouraged workers had a higher likelihood of being depressed $(b=0.632[0.171])$. Within the group of the non-employed, students $\left(b_{\text {men }}=-\right.$ $\left.0.526[0.144] ; b_{\text {women }}=-0.774[0.150]\right)$ had a lower likelihood of being depressed than the retired, while those inactive because of sickness or disability had a higher likelihood of being depressed $(b=3.367[0.147] ; b=3.268[0.161])$.

Finally, in Model 3, the relationships between depression and some categories of the unemployed and the non-employed were modified by the country's change in unemployment 
rate. With regard to men, in the previous model (Model 2), the results show that there was a significant difference between the unemployed who were seeking a job and those who were not, with the latter being more depressed. However, in countries that were strongly affected by the crisis - i.e., those with a high increase in unemployment rate - this difference became smaller. In these countries, unemployed men actively seeking work were more depressed $(b=$ 0.115 [0.034]) during the crisis, and those who were not seeking work were less depressed (b $=-0.085[0.031])$. With regard to the non-employed, homemaking men $(b=0.151[0.054])$ and women $(b=0.078[0.028])$ were more depressed in countries with a higher increase in the unemployment rate. Furthermore, male students $(b=0.067[0.030])$ and men who were nonemployed because of sickness or disability $(b=0.075[0.035])$ also had a higher likelihood of being depressed in countries that were strongly hit by the crisis. 
Table 4: Depression regressed on change in the unemployment rate, individual employment status, and the subcategories of the unemployed and the non-employed

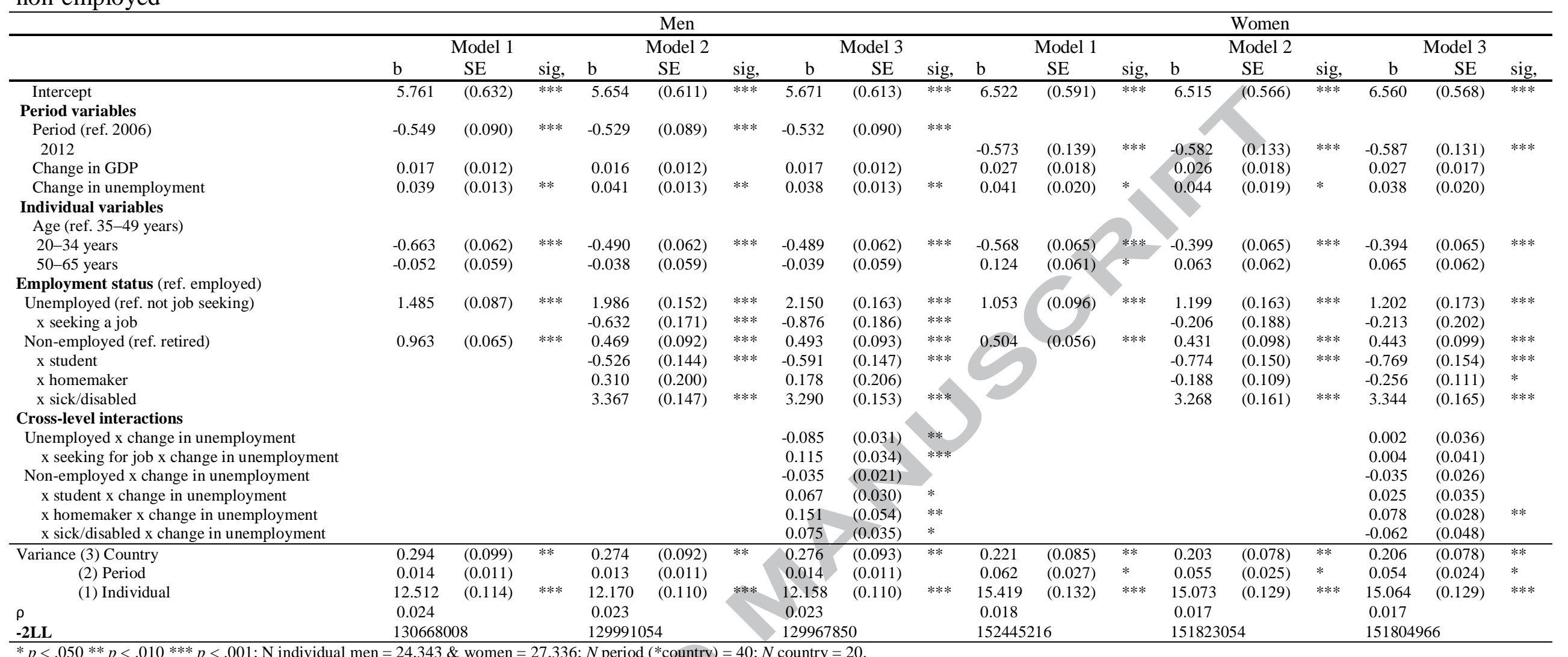

All models controlled for education, education ${ }^{2}$, marital status, income, and macroeconomic context variables (unemployment rate and GDP).

$\rho$ Variance at both higher levels: 3 and 2 (country + period $)=\left(\sigma_{\text {country }}^{2}+\sigma_{\text {period }}^{2}\right) /\left(\sigma_{\text {country }}^{2}+\sigma_{\text {period }}^{2}+\sigma_{\text {individual }}^{2}\right)$. 
By relying on the Jackknife procedure, we have checked for influential countries by deleting every country once from the analysis (Rodgers 1999). The results for the full models of Table 3 (Model 4) and Table 4 (Model 3) are shown in the appendix (Appendix 3, Tables A-H). We can conclude that the above mentioned effects of the change variables as well as of the crosslevel interaction terms with employment status and work conditions, are quite stable. There are only a few effects that become insignificant or, visa verse, significant; when one country was excluded (these effects are colored gray). For example, when Germany, France, Ireland or Poland are excluded from men's sample and Cyprus, the Netherlands or Sweden from women's sample the interaction effect between change in unemployment rate and marginal part-time work is only marginal significant or even insignificant (Appendix 3 A-C). Furthermore, the main effect of change in unemployment rate in Model 3 of Table 4; which is now that of the reference category, namely the employed, also becomes significant among women, when the UK, Hungary, the Netherlands, Norway, Portugal, Germany or Bulgaria are excluded (Appendix $3 \mathrm{G}-\mathrm{H}$ ). The changes in the sizes of the effects are however minor.

\section{DISCUSSION}

This study examined the impact of the current economic crisis on depressive feelings in Europe via employment status and conditions. Change in the unemployment rate was taken as the main indicator of the strength of the crisis. Our research yielded two main findings.

First, we did establish increases in the levels of depression in countries that have been strongly affected by the economic crisis, such as Cyprus and Spain. This finding is in line with a number of single-country studies (Economou et al., 2013; Gili et al., 2013; Madianos et al., 2011). However, this finding could not be extrapolated to the European region as a whole. In fact, a decreasing trend in depressive feelings was found between 2006 and 2012 in most European countries. Thus, the impact of the economic crisis in Europe is country-specific. The observed crisis effect was significantly stronger for men and for those between 35 and 49 years of age. Therefore, the gender gap in depression, with women having more depressive feelings (Van de Velde et al., 2010) than men, decreased in the countries hit hardest by the crisis. This is in line with the results of Eurofound, based on the European Quality of Life survey data (Eurofound, 2012). That survey reported that mental well-being has remained quite stable in Europe - although it has worsened in some specific countries (e.g., Spain, Ireland, Greece, and Hungary) — and the gender gap has slightly decreased. Our results also support the previous findings, mostly from single-country studies, that men are at an increased 
risk of depression and suicidality during times of economic adversity (Artazcoz et al., 2004; Barr et al., 2012; Dunlop \& Mletzko, 2011; Uutela, 2010; Wahlbeck \& McDaid, 2012).

Second, as hypothesized, the observed crisis effect on depressive symptoms is not just a reflection of an increase in unemployment and job insecurity. In fact, we found that changes in the prevalence of depressive feelings can only partly be ascribed to the changed composition of the working-age population. In countries hit hardest by the crisis, unemployment, non-employment, and the subsequent feelings of depression became more prevalent. However, our results also showed that some conditions of employment and subcategories of both unemployment and non-employment were differently related to depression, depending on the strength of the economic crisis. We found that the relationship between part-time work and depression was moderated by the recession: In countries characterized by a high increase in unemployment, marginal part-time working men and women were more likely to be depressed than in countries having no increase in unemployment. This can possibly be explained by the fact that in countries with high unemployment, marginal part-time work is somewhat forced upon individuals as the only way to remain employed in a shrinking labor market. Among women in particular, an additional explanation might be found in the additional worker effect (Bettio, 2012). These women were often full-time caregivers before the crisis, but were forced into the labor market as part-time workers by family economic needs (De Moortel, Vandenheede, \& Vanroelen, 2014) or because of a partner's job insecurity. However, we need to be cautious with this finding, as an additional sensitivity analysis applying the Jackknife Procedure showed that the moderation effect of change in unemployment rate on the relation between part-time work and depression is dependent on a number of specific countries included in the model. It is possible that some countries are special cases or that the number of countries and country-periods are not enough to find stable results. Among women, for example, the finding that the positive relation between marginal part-time work and depression is stronger in countries with an increase in unemployment, was no longer significant when the Netherlands are excluded. It is known that the Netherlands are a very unique case, as more than fifty percent of the women work parttime and it has been already highly normalized before the crisis (Boulin, Lallement, Messenger, \& Michon, 2006). However, to get a deeper insight in these policies on flexibalization of the labor market, and how this may be affected by the crisis, we recommend further country specific research.

In countries strongly affected by the crisis, the difference between unemployed men actively looking for a job and those not looking — with the latter being the more depressed- 
becomes smaller, because men actively seeking work were more depressed, while the discouraged workers were less depressed. Both formulated hypotheses are thus supported, but each only by a subgroup of the unemployed. In countries with a high increase in unemployment, those looking for a job are more depressed, probably because their chances of finding a new job are substantially lessened. By contrast, the discouraged workers are less depressed, possibly because they are more easily reconciled to their situation because it is experienced by many others, and, therefore, might be less stigmatizing during a recession (Clark et al., 2010; Clark, 2003).

Last, and as we partly expected, male students, men non-employed due to disability or sickness, and homemaking men and women are more depressed in countries with an increase in unemployment. Pessimistic labor market prospects due to high levels of unemployment and underemployment among youth — for example, involuntary part-time work, temporary jobs, and over-education - may bring about uncertainty and anxiety among students. In addition, an increase in student numbers was observed especially in countries hardest hit by the crisis, perhaps because economic contraction may encourage students to prolong their education (Bell \& Blanchflower, 2011). The finding that the disabled are more depressed can possibly be ascribed to reduced disability benefits and stricter criteria for sickness insurance, which could strengthen the health selection effect on those non-employed because of sickness or disability.

Finally, some limitations to this study should be acknowledged. First, the design of the study does not make it possible to draw any certain conclusions about causation or selection. However, we have attempted in various ways to take into account possible selection bias and problems of endogeneity. As was the case in previous cross-sectional studies, we sought to reduce the possible effect of selection by controlling for relevant confounding factors, such as education, income, and marital status. Previous depression is not predictive of becoming inadequately employed, but it does have an effect on the unemployed (Dooley et al., 2000). By making the distinction between the unemployed and the non-employed due to illness or disability, we could partially take into account the possible reverse causality in unemployment (Beland, Birch, \& Stoddart, 2002); however, not all selection bias is corrected in this way. Even if initial job loss is not caused by health problems, selection bias can occur because unemployment may have a detrimental impact on health (Paul \& Moser, 2009), and, subsequently, the unhealthy unemployed are less likely to find a new job than the more healthy unemployed (Stewart, 2001). The models also took into account the country's unemployment rate. In this way, we controlled for potential between-country differences in 
selection bias related to between-country variation in the proportions of the unemployed (Buffel, Dereuddre, \& Bracke, 2015). In addition, we tested interaction effects between the individual employment status and the national proportion of the unemployed. We did this because, in line with previous research (Clark et al., 2010), we could expect that in countries with low unemployment, unemployment would be less randomly distributed, and as a result would be more frequently considered a personal characteristic or a direct or indirect consequence of health selection (Mackenbach, 2012). But these interactions were not significant: The unemployed were not differently related to depression according to the national level of unemployment. With the available data, we could not as yet give a definitive answer concerning the direction of the relationships, and it is possible that both selection and causation processes were present. However, based on the meta-analysis of Paul and Moser (2009), which also included information from longitudinal studies, we know that the mental health selection effect on unemployment and job search is relatively weak.

Second, it is very difficult to define recession effects on health-related outcomes, such as depression. Our strength was that we directly incorporated macroeconomic change measurements - changes in the unemployment rate and GDP per inhabitant from 2005 to 2011 - while simultaneously controlling for the macroeconomic condition of each country before the crisis and for period effects (2006 versus 2012). However, there are only two waves of the ESS with information about depression available. As a result, we could only control for the period 2006 versus that of 2012. Therefore, our analyses are not completely "(time) trend adjusted."

Further, the economic crisis may also have indirect long-term consequences for mental health through its effect on public policies (de Belvis et al., 2012). Therefore, in a future study, we intend to examine the effect on depression of a country's welfare state institutions and austerity policies in response to the crisis, as well as the relationship between employment status and depression. There are already some indications that active labor market programs, strong social safety nets, and mental health prevention campaigns mitigate the negative mental health effects of recession (Cooper, 2011; Stuckler et al., 2009; Vuori, Silvonen, Vinokur, \& Price, 2002). Conversely, austerity policies and cost containment in the health sector might lead to a deterioration in health, and health care access and provisions (GeneBadia, Gallo, Hernandez-Quevedo, \& Garcia-Armesto, 2012; Karanikolos et al., 2013). The roll-out of activation programs and stricter entitlement criteria for disability benefits may also influence the relationship between non-employment and depression (Blomqvist, Burstrom \& Backhans, 2014) by moving previously inactive people back to the labor market. Moreover, 
characteristics of the welfare state, such as the degree of decommodification (the disability and unemployment benefit structure and its replacement rate and duration of payment) and defamiliarization (child care provisions and parental leave), may also influence the relationship between depression and individual employment status (Paul and Moser, 2009). In addition, it is argued in some literature that women are more vulnerable to austerity measures (Bettio, 2012; Karamessini \& Rubery, 2013). Therefore, gender differences in the indirect effects of the recession can be expected and should also be examined in future research.

In conclusion, a positive effect of a strong increase in unemployment -as an indicator of the strength of the economic crisis- on depression is found, taking each country's pre-crisis economic conditions into account. The observed changes in depressive feelings according to the strength of the crisis are not just simply a reflection of a variation in individual employment status and conditions, nor of variation in the levels of other individual risk factors for depression (age, household income, marital status, and education). Moreover, we have indications that in countries strongly affected by the present crisis, the recession is having differential effects on depression depending on gender, age, employment conditions (working hours), and certain subcategories of the unemployed and the non-employed.

\section{REFERENCIES}

Arrow, J.O. (1996). Estimating the influence of health as a risk factor on unemployment: A survival analysis of employment durations for workers surveyed in the German SocioEconomic Panel (1984-1990). Social Science \& Medicine, 42(12), 1651-1659. Doi 10.1016/0277-9536(95)00329-0

Artazcoz, L., Benach, J., Borrell, C., \& Cortes, I. (2004). Unemployment and mental health: Understanding the interactions among gender, family roles, and social class. American Journal of Public Health, 94(1), 82-88. Doi 10.2105/Ajph.94.1.82

Artazcoz, L., Benach, J., Borrell, C., \& Cortes, I. (2005). Social inequalities in the impact of flexible employment on different domains of psychosocial health. Journal of Epidemiology and Community Health, 59(9), 761-767. Doi 10.1136/jech.2004.028704 Artazcoz, L., Cortes, I., Puig-Barrachina, V., Benavides, F.G., Escriba-Aguir, V., \& Borrell, C. (2014). Combining employment and family in Europe: the role of family policies in health. European Journal of Public Health, 24(4), 649-655. Doi 10.1093/eurpub/ckt170 
Barr, B., Taylor-Robinson, D., Scott-Samuel, A., McKee, M., \& Stuckler, D. (2012). Suicides associated with the 2008-10 economic recession in England: time trend analysis. British Medical Journal, 345. Doi: Artn E5142Doi 10.1136/Bmj.E5142

Bartley, M. (1994). Unemployment and Ill Health - Understanding the Relationship. Journal of Epidemiology and Community Health, 48(4), 333-337. Doi 10.1136/jech.48.4.333

Baumbach, A., \& Gulis, G. (2014). Impact of financial crisis on selected health outcomes in Europe. European Journal of Public Health, 24(3), 399-403. Doi 10.1093/eurpub/cku042

Beland, F., Birch, S., \& Stoddart, G. (2002). Unemployment and health: contextual-level influences on the production of health in populations. Social Science \& Medicine, 55(11), 2033-2052. Doi 10.1016/S0277-9536(01)00344-6

Bell, D.N.F., \& Blanchflower, D.G. (2011). Young people and the Great Recession. Oxford Review of Economic Policy, 27(2), 241-267. Doi 10.1093/Oxrep/Grr011

Benach, J., Amable, M., Muntaner, C., \& Benavides, F.G. (2002). The consequences of flexible work for health: are we looking at the right place? Journal of Epidemiology and Community Health, 56(6), 405-406.

Benach, J., Benavides, F.G., Platt, S., Diez-Roux, A., \& Muntaner, C. (2000). The healthdamaging potential of new types of flexible employment: A challenge for public health researchers. American Journal of Public Health, 90(8), 1316-1317. Doi 10.2105/Ajph.90.8.1316

Benach, J., \& Muntaner, C. (2007). Precarious employment and health: developing a research agenda. Journal of Epidemiology and Community Health, 61(4), 276-277. Doi 10.1136/jech.2005.045237

Benach, J., Vives, A., Amable, M., Vanroelen, C., Tarafa, G., \& Muntaner, C. (2014a). Precarious employment: understanding an emerging social determinant of health. Annual Review of Public Health, 35, 229-253. Doi: 10.1146/annurev-publhealth032013-182500

Benavides, F.G., Benach, J., Diez-Roux, A. V., \& Roman, C. (2000). How do types of employment relate to health indicators? Findings from the Second European Survey on Working Conditions. Journal of Epidemiology and Community Health, 54(7), 494501. Doi 10.1136/jech.54.7.494

Bettio, F., Corsi, M., D'Ippoliti, C., Lyberaki, A., Lodovici, M.S. \& Verashchagina, A. (2012). The Impact of the economic crisis on the situation of women and men and on gender equality policies. Luxembourg: Publications Office of the European Union. 
Bielenski, H., Bosch, G., \& Wagner, A. (2002). Working time preferences in sixteen European countries. Dublin, Ireland: European Foundation for the Improvement of Living and Working Conditions (Eurofound).

Blanco, C., Okuda, M., Wright, C., Hasin, D.S., Grant, B.F., Liu, S.M., \& Olfson, M. (2008). Mental Health of College Students and Their Non-College-Attending Peers: Results From the National Epidemiologic Study on Alcohol and Related Conditions. Archives of General Psychiatry, 65(12), 1429-1437. Doi 10.1001/archpsyc.65.12.1429

Blomqvist, S., Burstrom, B., \& Backhans, M.C. (2014). Increasing health inequalities between women in and out of work - the impact of recession or policy change? A repeated cross-sectional study in Stockholm county, 2006 and 2010. International Journal for Equity in Health, 13. Doi 10.1186/1475-9276-13-51

Boulin, J., Lallement, M., Messenger, J.C. \& Michon F. (2006). Decent working time: New trends, new issues. Geneva, International Labour Office.

Buffel, V., Dereuddre, R., \& Bracke, P. (2015). Medicalisation of the uncertainty? An empirical study of the relationships between unemployment or job insecurity, professional care seeking, and the consumption of antidepressants. European Sociological Review. Doi 10.1093/esr/jcv004

Buffel, V., Van de straat, V, \& Bracke, P. (2015). Employment status and mental health care use in times of economic contraction: a repeated cross-sectional study in Europe, using a three-level model. International Journal for Equity in Health. Doi:10.1186/s12939015-0153-3

Bryan, M. L. \& Jenkins S.P. (2013). Regression Analysis of Country Effects Using Multilevel Data: A Coutionary Table. UK Institute for social \& economic research: Essex.

Catalano, R.A., Dooley, D., \& Jackson, R.L. (1985). Economic Antecedents of Help Seeking - Reformulation of Time-Series Tests. Journal of Health and Social Behavior, 26(2), 141-152. Doi 10.2307/2136603

Cooper, B. (2011). Economic recession and mental health: an overview. Neuropsychiatry, 25(3), 113-117. 
De Moortel, D., Vandenheede, H., \& Vanroelen, C. (2014). Contemporary employment arrangements and mental well-being in men and women across Europe: a crosssectional study. International Journal for Equity in Health, 13(1), 90. Doi 10.1186/s12939-014-0090-6

De Vogli, R., Vieno, A., \& Lenzi, M. (2014). Mortality due to mental and behavioral disorders associated with the Great Recession (2008-10) in Italy: a time trend analysis. European Journal of Public Health, 24(3), 419-421. Doi 10.1093/eurpub/ckt173

Dooley, D. (2003). Unemployment, underemployment, and mental health: Conceptualizing employment status as a continuum. American Journal of Community Psychology, 32(1-2), 9-20. Doi 10.1023/A:1025634504740

Dooley, D., \& Catalano, R. (1984). Why the Economy Predicts Help-Seeking - a Test of Competing Explanations. Journal of Health and Social Behavior, 25(2), 160-176. Doi $10.2307 / 2136666$

Dooley, D., Prause, J., \& Ham-Rowbottom, K. A. (2000). Underemployment and depression: Longitudinal relationships. Journal of Health and Social Behavior, 41(4), 421-436. Doi $10.2307 / 2676295$

Doshi, J.A., Cen, L., \& Polsky, D. (2008). Depression and retirement in late middle-aged U.S. workers. Health Services Research, 43(2), 693-713. Doi 10.1111/j.14756773.2007.00782.x

Dunlop, B.W., \& Mletzko, T. (2011). Will current socioeconomic trends produce a depressing future for men? British Journal of Psychiatry, 198(3), 167-168. Doi 10.1192/bjp.bp.110.084210

Economou, M., Madianos, M., Peppou, L. E., Patelakis, A., \& Stefanis, C.N. (2013). Major depression in the Era of economic crisis: A replication of a cross-sectional study across Greece. Journal of Affective Disorders, 145(3), 308-314. Doi 10.1016/j.jad.2012.08.008

Eurofound (2007). Part-time work in Europe. Dublin, Ireland: European Foundation for the Improvement of Living and Working Conditions (Eurofound).

Eurofound (2012). Third European Quality of Life Survey - Quality of life in Europe: Impacts of the crisis. Luxembourg: Publications Office of the European Union.

Eurofound (2013). Impact of the crisis on working conditions in Europe (pp. 1-70). Dublin, Ireland: European Foundation for the Improvement of Living and Working Conditions (Eurofound). 
European Commission (2010) European employment Observatory Review: Self-employment in Europe 2010. Luxembourg: Publications Office of the European Union.

Fairbrother, M. (2014). Two Multi-level Modeling Techniques for Analyzing comparative Longitudinal Survey Data sets. Political Science Research and Methods, 2, 22. Doi 10.1017/psrm.2013.24

Fenwick, R., \& Tausig, M. (1994). The Macroeconomic Context of Job Stress. Journal of Health and Social Behavior, 35(3), 266-282. Doi 10.2307/2137280

Fernandez-Rivas, A., \& Gonzalez-Torres, M.A. (2013). The economic crisis in Spain and its impact on the mental health of children and adolescents. European Child \& Adolescent Psychiatry, 22(9), 583-586. Doi 10.1007/s00787-013-0465-z

Fone, D., Dunstan, F., Williams, G., Lloyd, K., \& Palmer, S. (2007). Places, people and mental health: a multi-level analysis of economic inactivity. Social Science \& Medicine, 64(3), 633-645. Doi 10.1016/j.socscimed.2006.09.020

Gene-Badia, J., Gallo, P., Hernandez-Quevedo, C., \& Garcia-Armesto, S. (2012). Spanish health care cuts: Penny wise and pound foolish? Health Policy, 106(1), 23-28. Doi 10.1016/j.healthpol.2012.02.001

Gili, M., Roca, M., Basu, S., McKee, M., \& Stuckler, D. (2013). The mental health risks of economic crisis in Spain: evidence from primary care centres, 2006 and 2010. European Journal of Public Health, 23(1), 103-108. Doi 10.1093/eurpub/cks035

Goldman-Mellor, S.J., Saxton, K.B., \& Catalano, R.C. (2010). Economic Contraction and Mental Health, A Review of the Evidence, 1990-2009. International Journal of Mental Health, 39(2), 6-31. DOI 10.2753/IMH0020-7411390201

Hunt, J., \& Eisenberg, D. (2010). Mental Health Problems and Help-Seeking Behavior Among College Students. Journal of Adolescent Health, 46(1), 3-10. Doi 10.1016/j.jadohealth.2009.08.008

ILO. (2006). Global Employment Trends for Youth. Geneva: International Labour Organization (ILO).

Jahoda, M. (1981). Work, Employment, and Unemployment - Values, Theories, and Approaches in Social-Research. American Psychologist, 36(2), 184-191. Doi 10.1037//0003-066x.36.2.184

Jamal, M. (1997). Job stress, satisfaction, and mental health: An empirical examination of self-employed and non-self-employed Canadians. Journal of Small Business Management, 35(4), 48-57. 
Janlert, U., \& Hammarstrom, A. (2009). Which theory is best? Explanatory models of the relationship between unemployment and health. BMC Public Health, 9, 235. Doi $10.1186 / 1471-2458-9-235$

Karamessini, M. (2013). Introduction - Women's vulnerability to recession and austerity. In J.R. Maria Karamessini (Ed.), Women and Austerity: The Economic Crisis and the Future for Gender Equality. London: Routledge.

Karanikolos, M., Mladovsky, P., Cylus, J., Thomson, S., Basu, S., Stuckler, D., . . McKee, M. (2013). Financial crisis, austerity, and health in Europe. Lancet, 381(9874), 13231331. Doi 10.1016/S0140-6736(13)60102-6

Katikireddi, S.V., Niedzwiedz, C.L., \& Popham, F. (2012). Trends in population mental health before and after the 2008 recession: a repeat cross-sectional analysis of the 1991-2010 Health Surveys of England. BMJ Open, 2(5). Doi 10.1136/bmjopen-2012001790

Kentikelenis, A., Karanikolos, M., Papanicolas, I., Basu, S., McKee, M., \& Stuckler, D. (2011). Health effects of financial crisis: omens of a Greek tragedy. Lancet, 378(9801), 1457-1458. Doi 10.1016/S0140-6736(11)61556-0

Keuskamp, D., Ziersch, A.M., Baum, F.E., \& LaMontagne, A.D. (2013). Precarious Employment, Psychosocial Working Conditions, and Health: Cross-Sectional Associations in a Population-Based Sample of Working Australians. American Journal of Industrial Medicine, 56(8), 838-844. Doi 10.1002/Ajim.22176

Madianos, M., Economou, M., Alexiou, T., \& Stefanis, C. (2011). Depression and economic hardship across Greece in 2008 and 2009: two cross-sectional surveys nationwide. Social Psychiatry and Psychiatric Epidemiology, 46(10), 943-952. Doi $10.1007 / \mathrm{s} 00127-010-0265-4$

Martens, M.F.J., Nijhuis, F.J.N., Van Boxtel, M.P.J., \& Knottnerus, J.A. (1999). Flexible work schedules and mental and physical health. A study of a working population with non-traditional working hours. Journal of Organizational Behavior, 20(1), 35-46. Doi 10.1002/(Sici)1099-1379(199901)20:1<35::Aid-Job879>3.0.Co;2-Z

McKee-Ryan, F.M., \& Harvey, J. (2011). "I Have a Job, But ... ": A Review of Underemployment. Journal of Management, 37(4), 962-996. Doi $10.1177 / 0149206311398134$

McKee-Ryan, F. M., Song, Z.L., Wanberg, C. R., \& Kinicki, A. J. (2005). Psychological and physical well-being during unemployment: A meta-analytic study. Journal of Applied Psychology, 90(1), 53-76. Doi 10.1037/0021-9010.90.1.53 
Mental Health Commission (2012). The Human Cost: An overview of the evidence on economic adversity and mental health and recommendations for action. Ireland: Mental Health Commission.

Mirowsky, J. (1999). Analyzing Associations Between Mental Health and Social Circumstances. In C. S. Aneshensel. J. C. Phelan (Eds.), Handbook of the Sociology of Mental Health (pp. 105-123). New York: Kluwer Academic/Plenum Publishers.

Mirowsky, J., \& Ross, C. E. (2003). Social causes of psychological distress. Hawthorne: Aldine De Gruyter.

Missinne, S., Vandeviver, C., Van de Velde, S. \& Bracke, P. (2014). Measurement equivalence of the CES-D 8 depression-scale among the ageing population in eleven European countries. Social Science Research, 46, 38-47. Doi. org/10.1016/j.ssresearch.2014.02.006

Morris, J.K., Cook, D.G., \& Shaper, A. G. (1994). Loss of Employment and Mortality. British Medical Journal, $\quad 308(6937), \quad$ 1135-1139. Doi http://dx.doi.org/10.1136/bmj.308.6937.1135

Noelke, C., \& Beckfield, J. (2014). Recessions, Job Loss, and Mortality Among Older US Adults. American Journal of Public Health, 104(11), e126-e134. Doi 10.2105/AJPH.2014.302210

OECD (2005). What are equivalence scales? Organization for economic co-operation and development. Retrieved from http://www.oecd.org/dataoecd/61/52/35411111.pdf

Parslow, R.A., Jorm, A.F., Christensen, H., Rodgers, B., Strazdins, L., \& D'Souza, R.M. (2004). The associations between work stress and mental health: A comparison of organizationally employed and self-employed workers. Work and Stress, 18(3), 231244. Doi 10.1080/14749730412331318649

Paul, K.I., \& Moser, K. (2009). Unemployment impairs mental health: Meta-analyses. Journal of Vocational Behavior, 74(3), 264-282. Doi 10.1016/j.jvb.2009.01.001

Quaade, T., Engholm, G., Johansen, A. M., \& Moller, H. (2002). Mortality in relation to early retirement in Denmark: a population-based study. Scandanavian Journal of Public Health, 30(3), 216-222. Doi 10.1080/14034940210134022

Radloff, L.S. (1977). The CES-D Scale: A Self-Report Depression Scale for Research in the General Population. Applied Psychological Measurement, 1, 385-401. Doi $10.1177 / 014662167700100306$ 
Roca, M., Gili, M., Garcia-Campayo, J., \& Garcia-Toro, M. (2013). Economic crisis and mental health in Spain. Lancet, 382(9909), 1977-1978. Doi 10.1016/S0140$6736(13) 62650-1$

Rodgers, J.L. (1999). The Bootstrap, the Jackknife, and the Randomization Test: A Sampling Taxonomy. Multivariate Behavioral Research 34:441. Rubery, J., \& Rafferty, A. (2013). Women and recession revisited. Work Employment and Society, 27(3), 414432. Doi 10.1177/0950017012460314

Schmitz, H. (2011). Why are the unemployed in worse health? The causal effect of unemployment on health. Labour Economics, 18(1), 71-78. Doi 10.1016/j.labeco.2010.08.005

Schroder, M. (2013). Jobless now, sick later? Investigating the long-term consequences of involuntary job loss on health. Advances in Life Course Research, 18(1), 5-15. Doi 10.1016/j.alcr.2012.08.001

Stegmueller, D. (2013). How many countries for multi-level modeling? A comparison of Frequentist and Bayesian approaches. American Journal of Political Science, 57(3), 748-761. Doi 10.1111/ajps.12001

Stewart, J.M. (2001). The impact of health status on the duration of unemployment spells and the implications for studies of the impact of unemployment on health status. Journal of Health Economics, 20(5), 781-796. Doi 10.1016/S0167-6296(01)00087-X

Stuckler, D., Basu, S., Suhrcke, M., Coutts, A., \& McKee, M. (2009). The public health effect of economic crises and alternative policy responses in Europe: an empirical analysis. Lancet, 374(9686), 315-323. Doi 10.1016/S0140-6736(09)61124-7

Tausig, M., \& Fenwick, R. (1999). Recession and well-being. Journal of Health and Social Behavior, 40(1), 1-16. Doi 10.2307/2676375

Turner, J.B. (1995). Economic Context and the Health-Effects of Unemployment. Journal of Health and Social Behavior, 36(3), 213-229. Doi 10.2307/2137339

Uutela, A. (2010). Economic crisis and mental health. Current Opinion in Psychiatry, 23(2), 127-130. Doi 10.1097/Yco.0b013e328336657d

Van de Velde, S., Bracke, P., Levecque, K., \& Meuleman, B. (2010). Gender differences in depression in 25 European countries after eliminating measurement bias in the CES-D 8. Social Science Research, 39(3), 396-404. Doi 10.1016/j.ssresearch.2010.01.002 
Van der Bracht, K., \& Van de Putte, B. (2014). Homonegativity among first and second generation migrants in Europe: The interplay of time trends, origin, destination and religion. Social Science Research, 48, 108-120. Doi 10.1016/j.ssresearch.2014.05.011

Virtanen, M., Kivimaki, M., Elovainio, M., Vahtera, J., \& Ferrie, J. E. (2003). From insecure to secure employment: changes in work, health, health related behaviours, and sickness absence. Occupational and Environmental Medicine, 60(12), 948-953. Doi 10.1136/oem.60.12.948

Virtanen, M., Kivimaki, M., Joensuu, M., Virtanen, P., Elovainio, M., \& Vahtera, J. (2005). Temporary employment and health: a review. International Journal of Epidemiology, 34(3), 610-622. Doi 10.1093/Ije/Dyi024

Virtanen, P., Kivimaki, M., Vahtera, J., \& Koskenvuo, M. (2006). Employment status and differences in the one-year coverage of physician visits: different needs or unequal access to services? Bmc Health Services Research, 6. Doi 10.1186/1472-6963-6-123

Vuori, J., Silvonen, J., Vinokur, A.D., \& Price, R.H. (2002). The Tyohon Job Search Program in Finland: benefits for the unemployed with risk of depression or discouragement. Journal of Occupational Health Psychology, 7(1), 5-19. Doi 10.1037//10768998.7.1.5

Wahlbeck, K., \& McDaid, D. (2012). Actions to alleviate the mental health impact of the economic crisis. World Psychiatry, 11(3), 139-145.

Wang, J.L., Smailes, E., Sareen, J., Fick, G.H., Schmitz, N., \& Patten, S.B. (2010). The Prevalence of Mental Disorders in the Working Population Over the Period of Global Economic Crisis. Canadian Journal of Psychiatry-Revue Canadienne de Psychiatrie, 55(9), 598-605. 


\section{APPENDIX}

\begin{tabular}{|c|c|c|c|c|c|c|c|c|c|c|c|c|c|}
\hline \multicolumn{14}{|c|}{ Appendix 1: Macroeconomic indicators per country for 2005 and 2011} \\
\hline & & \multicolumn{2}{|c|}{$\%$ unemployment } & \multicolumn{2}{|c|}{$\%$ male unemployment } & \multicolumn{2}{|c|}{$\%$ female unemployment } & \multicolumn{2}{|c|}{ youth unemployment } & \multicolumn{2}{|c|}{ GDP per capita } & \multicolumn{2}{|c|}{$\%$ GDP change previous year } \\
\hline & & 2005 & 2011 & 2005 & 2011 & 2005 & 2011 & 2005 & 2011 & 2005 & 2011 & 2005 & 2011 \\
\hline \multirow[t]{3}{*}{ Weaker } & Germany & 11.2 & 5.8 & 11.4 & 6.1 & 10.9 & 5.6 & 15.4 & 8.5 & 27000 & 31900 & 0.7 & 3.3 \\
\hline & Poland & 17.9 & 9.7 & 16.7 & 9.0 & 19.4 & 10.4 & 36.9 & 25.8 & 6400 & 9600 & 3.6 & 4.5 \\
\hline & Switzerland & 4.5 & 4.1 & 4.5 & 3.7 & 4.5 & 4.4 & 8.8 & 7.7 & 41300 & 60300 & 2.7 & 1.8 \\
\hline \multirow[t]{4}{*}{ Weak } & Norway & 4.5 & 3.3 & 4.7 & 3.5 & 4.3 & 3.1 & 11.4 & 8.7 & 52900 & 71300 & 2.6 & 1.3 \\
\hline & Sweden & 7.7 & 7.8 & 7.7 & 7.8 & 7.6 & 7.7 & 22.6 & 22.8 & 33000 & 40800 & 3.2 & 2.9 \\
\hline & Belgium & 8.5 & 7.2 & 7.6 & 7.1 & 9.5 & 7.2 & 21.5 & 18.7 & 29000 & 33600 & 1.8 & 1.8 \\
\hline & Slovakia & 16.4 & 13.7 & 15.6 & 13.7 & 17.4 & 13.7 & 30.4 & 33.7 & 7100 & 12800 & 6.7 & 3.0 \\
\hline \multirow[t]{2}{*}{ Fairly weak } & Netherlands & 5.3 & 4.4 & 4.9 & 4.5 & 5.8 & 4.4 & 9.4 & 7.6 & 31500 & 35900 & 2.0 & 0.9 \\
\hline & France & 8.9 & 9.2 & 8.2 & 8.8 & 9.7 & 9.5 & 21.0 & 22.6 & 27300 & 30700 & 1.8 & 2.0 \\
\hline \multirow[t]{3}{*}{ Average } & Finland & 8.4 & 7.8 & 8.2 & 8.4 & 8.6 & 7.1 & 20.1 & 20.1 & 30000 & 35000 & 2.9 & 2.8 \\
\hline & Bulgaria & 10.1 & 11.3 & 10.3 & 12.3 & 10.0 & 10.1 & 21.0 & 25.0 & 3000 & 5200 & 6.4 & 1.8 \\
\hline & Cyprus & 5.3 & 7.9 & 4.4 & 8.1 & 6.5 & 7.7 & 13.9 & 22.4 & 18400 & 21000 & 3.9 & 0.4 \\
\hline \multirow[t]{4}{*}{ Fairly strong } & United Kingdom & 4.8 & 8.1 & 5.2 & 8.7 & 4.3 & 7.4 & 12.8 & 21.3 & 31000 & 28200 & 3.2 & 1.1 \\
\hline & Denmark & 4.8 & 7.6 & 4.4 & 7.7 & 5.3 & 7.5 & 8.6 & 14.2 & 38300 & 43200 & 2.4 & 1.1 \\
\hline & Slovenia & 6.5 & 8.2 & 6.1 & 8.2 & 7.1 & 8.2 & 15.9 & 15.7 & 14400 & 17600 & 4.0 & 0.7 \\
\hline & Hungary & 7.2 & 10.9 & 7.0 & 11.0 & 7.4 & 10.9 & 19.4 & 26.1 & 8800 & 9900 & 4.0 & 1.6 \\
\hline \multirow[t]{2}{*}{ Strong } & Portugal & 8.8 & 12.9 & 8.7 & 12.6 & 8.8 & 13.2 & 20.7 & 30.3 & 14600 & 16100 & 0.8 & -1.3 \\
\hline & Estonia & 8.0 & 12.3 & 9.2 & 13.1 & 6.9 & 11.6 & 15.1 & 22.4 & 8300 & 12100 & 8.9 & 8.7 \\
\hline \multirow[t]{2}{*}{ Stronger } & Ireland & 4.4 & 14.7 & 4.6 & 17.8 & 4.1 & 10.8 & 8.6 & 29,1 & 39200 & 35500 & 6.1 & 2.2 \\
\hline & Spain & 9.2 & 21.4 & 7.1 & 21.1 & 12.0 & 21.8 & 19.6 & 46.2 & 21000 & 22700 & 3.6 & 0.1 \\
\hline \multicolumn{2}{|c|}{ Source: Eurostat and OECD. } & & & & & & & 1 & & & & & \\
\hline
\end{tabular}


Appendix 2: Depression regressed on change in unemployment, with and without controlling for individual employment status, men and women together

\begin{tabular}{|c|c|c|c|c|c|c|c|c|c|c|c|c|}
\hline & \multicolumn{3}{|c|}{ Model 1} & \multicolumn{3}{|c|}{ Model 2} & \multicolumn{3}{|c|}{ Model 3} & \multicolumn{3}{|c|}{ Model 4} \\
\hline & $\mathrm{b}$ & SE & sig. & $\mathrm{b}$ & SE & sig. & $\mathrm{b}$ & SE & sig. & $\mathrm{b}$ & SE & sig \\
\hline Intercept & 6.247 & $(0.580)$ & $* * *$ & 6.018 & $(0.583)$ & $* * *$ & 5.904 & $(0.581)$ & $* * *$ & 5.882 & $(0.582)$ & $* * *$ \\
\hline \multicolumn{13}{|l|}{ Context variables } \\
\hline GDP 2005 & -0.054 & $(0.011)$ & $* * *$ & -0.052 & $(0.011)$ & $* * *$ & -0.051 & $(0.011)$ & $* * *$ & -0.051 & $(0.011)$ & $* * *$ \\
\hline Unemployment rate 2005 & 0.012 & $(0.044)$ & & 0.037 & $(0.045)$ & & 0.034 & $(0.045)$ & & 0.033 & $(0.045)$ & \\
\hline \multicolumn{13}{|l|}{ Period variables } \\
\hline \multicolumn{13}{|l|}{ Period (ref. 2006) } \\
\hline 2012 & -0.370 & $(0.089)$ & $* * *$ & -0.557 & $(0.109)$ & $* * *$ & -0.580 & $(0.110)$ & $* * *$ & -0.580 & $(0.110)$ & $* * *$ \\
\hline Change in GDP & & & & 0.021 & $(0.014)$ & & 0.023 & $(0.015)$ & & 0.023 & $(0.015)$ & \\
\hline Change in unemployment rate & & & & 0.051 & $(0.015)$ & $* * *$ & 0.042 & $(0.016)$ & $* *$ & 0.069 & $(0.017)$ & $* * *$ \\
\hline \multicolumn{13}{|l|}{ Individual variables } \\
\hline Gender (ref. men) & 0.522 & $(0.034)$ & $* * *$ & 0.522 & $(0.034)$ & $* * *$ & 0.522 & $(0.034)$ & $* * *$ & 0.447 & $(0.034)$ & $* * *$ \\
\hline \multicolumn{13}{|l|}{ Age (ref. 35-49 years) } \\
\hline $20-34$ years & -0.550 & $(0.045)$ & $* * *$ & -0.548 & $(0.045)$ & $* * *$ & -0.620 & $(0.045)$ & $* * *$ & -0.595 & $(0.046)$ & $* * *$ \\
\hline $50-65$ years & 0.197 & $(0.041)$ & $* * *$ & 0.198 & $(0.041)$ & $* * *$ & 0.050 & $(0.042)$ & & 0.077 & $(0.043)$ & \\
\hline \multicolumn{13}{|l|}{ Employment status (ref. employed) } \\
\hline Unemployed & & & & & & & 1.267 & $(0.065)$ & $* * *$ & 1.260 & $(0.065)$ & $* * *$ \\
\hline Non-employed & & & & & & & 0.702 & $(0.042)$ & $* * *$ & 0.701 & $(0.042)$ & $* * *$ \\
\hline \multicolumn{13}{|l|}{ Cross-level interactions } \\
\hline Women $\mathrm{x}$ change in unemployment & & & & & & & & & & -0.019 & $(0.006)$ & $* *$ \\
\hline Age $20-34$ y change in unemployment & & & & & & & & & & -0.024 & $(0.010)$ & * \\
\hline Age $50-65 y$ x change in unemployment & & & & & & & & & & -0.027 & $(0.010)$ & $* *$ \\
\hline Variance (3) Country & 0.229 & $(0.086)$ & $* *$ & 0.238 & $(0.084)$ & ** & 0.236 & $(0.083)$ & $* *$ & 0.236 & $(0.083)$ & $* *$ \\
\hline (2) Period & 0.068 & $(0.025)$ & $* *$ & 0.040 & $(0.016)$ & $*$ & 0.041 & $(0.017)$ & $*$ & 0.040 & $(0.016)$ & $*$ \\
\hline (1) Individual & 14.252 & $(0.089)$ & $* * *$ & 14.252 & $(0.089)$ & $* * *$ & 14.106 & $(0.088)$ & $* * *$ & 14.102 & $(0.088)$ & $* * *$ \\
\hline$\rho$ & 0.020 & & & 0.019 & & & 0.019 & & & 0.019 & & \\
\hline$-2 \mathrm{LL}$ & 284079 & & & 284070 & & & 2835400 & & & 283526 & & \\
\hline
\end{tabular}

$* p<.050 * * p<.010 * * * p<.001 ; N$ individual $=51,679$ (men and women pooled) $N$ period $(*$ country $)=40 ; N$ country $=20$

All models controlled for education, education ${ }^{2}$, marital status, and income.

$\rho$ Variance at both higher levels: 3 and 2 (country + period $)=\left(\sigma_{\text {country }}^{2}+\sigma_{\text {period }}^{2}\right) /\left(\sigma_{\text {country }}^{2}+\sigma_{\text {period }}^{2}+\sigma_{\text {individual }}^{2}\right)$. 


\begin{tabular}{|c|c|c|c|c|c|c|c|c|c|c|c|c|c|c|c|c|c|c|c|c|c|c|c|c|c|c|c|c|c|c|}
\hline \multirow[t]{2}{*}{ Without } & \multicolumn{3}{|c|}{ Belgium } & \multicolumn{3}{|c|}{ Bulgaria } & \multicolumn{3}{|l|}{ Swizz } & \multicolumn{3}{|c|}{ Cyprus } & \multicolumn{3}{|c|}{ Germany } & \multicolumn{3}{|c|}{ Denmark } & \multicolumn{3}{|c|}{\begin{tabular}{|l} 
Estonia \\
\end{tabular}} & \multicolumn{3}{|l|}{ Spain } & \multicolumn{3}{|c|}{ Finland } & \multicolumn{3}{|c|}{ France } \\
\hline & $\mathrm{b}$ & SE & sig & $\mathrm{b}$ & SE & sig & $\mathrm{b}$ & SE & sig & $\mathrm{b}$ & SE & sig & $\mathrm{b}$ & $\mathrm{SE}$ & sig & $\mathrm{b}$ & SE & sig & $\mathrm{b}$ & $\mathrm{SE}$ & sig & $\mathrm{b}$ & SE & sig & $\mathrm{b}$ & SE & sig & $\mathrm{b}$ & $\mathrm{SE}$ & sig \\
\hline Intercept & $\begin{array}{ll}7,24 \\
5\end{array}$ & \begin{tabular}{|l|}
0,66 \\
2 \\
\end{tabular} & $\begin{array}{l}* * \\
*\end{array}$ & $\begin{array}{l}7,21 \\
5\end{array}$ & \begin{tabular}{|l|}
0,69 \\
0
\end{tabular} & $\begin{array}{l}* * \\
* \\
*\end{array}$ & $\begin{array}{l}7,26 \\
9\end{array}$ & \begin{tabular}{|l|}
0,66 \\
2 \\
\end{tabular} & $\begin{array}{l}* * * \\
*\end{array}$ & $\begin{array}{l}7,71 \\
1\end{array}$ & \begin{tabular}{|l|}
0,68 \\
6 \\
\end{tabular} & $\begin{array}{l}* * \\
*\end{array}$ & \begin{tabular}{|l|l|}
7,45 \\
5
\end{tabular} & \begin{tabular}{|l}
0,67 \\
6
\end{tabular} & $\begin{array}{l}* * \\
*\end{array}$ & $\begin{array}{l}7,24 \\
0\end{array}$ & $\begin{array}{l}0,66 \\
4\end{array}$ & $\begin{array}{l}* * \\
* \\
*\end{array}$ & \begin{tabular}{|l|}
7,17 \\
3 \\
\end{tabular} & $\begin{array}{l}0,67 \\
9\end{array}$ & $\begin{array}{l}* * \\
*\end{array}$ & $\begin{array}{l}7,36 \\
4\end{array}$ & $\begin{array}{l}0,66 \\
5\end{array}$ & $\begin{array}{l}* * * \\
* \\
\end{array}$ & $\begin{array}{l}7,24 \\
9\end{array}$ & $\begin{array}{l}0,65 \\
9\end{array}$ & \begin{tabular}{|l|}
$* *$ \\
$*$ \\
\end{tabular} & $\begin{array}{l}7,25 \\
1\end{array}$ & $\begin{array}{l}0,66 \\
1\end{array}$ & $\begin{array}{l}* * * \\
*\end{array}$ \\
\hline Context variables & & & & & & & & & & & & & & & & & & & & & & & & & & & & & & \\
\hline GDP & $\begin{array}{l} \\
0,04 \\
6\end{array}$ & \begin{tabular}{|l|}
0,01 \\
3
\end{tabular} & $\begin{array}{l}* * \\
*\end{array}$ & $\begin{array}{l} \\
0,04 \\
8\end{array}$ & \begin{tabular}{|l}
0,01 \\
4
\end{tabular} & $\begin{array}{l}* * \\
* \\
*\end{array}$ & $\begin{array}{l} \\
0,04 \\
7\end{array}$ & \begin{tabular}{|l}
0,01 \\
3
\end{tabular} & $\begin{array}{l}* * \\
*\end{array}$ & $\begin{array}{l} \\
0,05 \\
4\end{array}$ & \begin{tabular}{|l|}
0,01 \\
3
\end{tabular} & $\begin{array}{l}* * \\
*\end{array}$ & \begin{tabular}{|l|}
- \\
0,04 \\
9
\end{tabular} & \begin{tabular}{|l|}
0,01 \\
3
\end{tabular} & $\begin{array}{l}* * \\
*\end{array}$ & $\begin{array}{l}- \\
0,04 \\
6\end{array}$ & \begin{tabular}{|l|}
0,01 \\
3
\end{tabular} & $\begin{array}{l}* * \\
* \\
*\end{array}$ & \begin{tabular}{|l|} 
\\
0,04 \\
5
\end{tabular} & $\begin{array}{l}0,01 \\
3\end{array}$ & $\begin{array}{l}* * \\
*\end{array}$ & $\begin{array}{l} \\
0,04 \\
9\end{array}$ & $\begin{array}{l}0,01 \\
3 \\
\end{array}$ & $\begin{array}{l}* * \\
*\end{array}$ & $\begin{array}{l} \\
0,04 \\
5\end{array}$ & $\begin{array}{l}0,01 \\
3\end{array}$ & \begin{tabular}{|l|}
$* *$ \\
$*$
\end{tabular} & $\begin{array}{l}- \\
0,04 \\
6\end{array}$ & $\begin{array}{l}0,01 \\
3\end{array}$ & $\begin{array}{l}* * \\
*\end{array}$ \\
\hline Unemployment rate & $\begin{array}{l}0,03 \\
9 \\
\end{array}$ & \begin{tabular}{|l|l}
0,05 \\
0
\end{tabular} & & $\begin{array}{l}0,03 \\
7 \\
\end{array}$ & \begin{tabular}{|l|l}
0,05 \\
1
\end{tabular} & & $\begin{array}{l}0,03 \\
8 \\
\end{array}$ & \begin{tabular}{|l|l|}
0,05 \\
0 \\
\end{tabular} & & $\begin{array}{l}0,00 \\
6\end{array}$ & \begin{tabular}{|l|l}
0,05 \\
1
\end{tabular} & & \begin{tabular}{|l|}
0,02 \\
6 \\
\end{tabular} & \begin{tabular}{|l}
0,05 \\
2 \\
\end{tabular} & & $\begin{array}{l}0,04 \\
0 \\
\end{array}$ & $\begin{array}{l}0,05 \\
0 \\
\end{array}$ & & \begin{tabular}{|l|}
0,04 \\
0 \\
\end{tabular} & $\begin{array}{l}0,05 \\
0\end{array}$ & & $\begin{array}{l}0,02 \\
9\end{array}$ & $\begin{array}{l}0,05 \\
0\end{array}$ & & $\begin{array}{l}0,04 \\
2\end{array}$ & $\begin{array}{l}0,05 \\
0\end{array}$ & & $\begin{array}{l}0,04 \\
0\end{array}$ & $\begin{array}{l}0,05 \\
0\end{array}$ & \\
\hline Period variables & & & & & & & & & & & & & & & & & & & & & & & $\Delta$ & & & & & & & \\
\hline Period (ref, 2006) & & & & & & & & & & & & & & & & & & & & & & 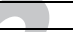 & & & & & & & & \\
\hline 2012 & $\begin{array}{l}- \\
0,56 \\
7\end{array}$ & \begin{tabular}{|l|}
0,08 \\
8
\end{tabular} & $\begin{array}{l}* * \\
*\end{array}$ & $\begin{array}{l}0,50 \\
9\end{array}$ & \begin{tabular}{|l|}
0,09 \\
3
\end{tabular} & $\begin{array}{l}* * \\
*\end{array}$ & $\begin{array}{l}0,54 \\
7\end{array}$ & \begin{tabular}{|l|l|}
0,09 \\
7
\end{tabular} & $\begin{array}{l}* * \\
*\end{array}$ & $\begin{array}{l}0,54 \\
6\end{array}$ & \begin{tabular}{|l|}
0,09 \\
2
\end{tabular} & $\begin{array}{l}* * \\
*\end{array}$ & $\begin{array}{l}0,60 \\
7\end{array}$ & \begin{tabular}{|l}
0,09 \\
0
\end{tabular} & $\begin{array}{l}* * \\
*\end{array}$ & $\begin{array}{l}0,53 \\
9\end{array}$ & \begin{tabular}{|l|}
0,09 \\
2
\end{tabular} & $\begin{array}{l}* * \\
*\end{array}$ & $\begin{array}{l}0,54 \\
7\end{array}$ & $\begin{array}{l}0,09 \\
3\end{array}$ & $\begin{array}{ll}* * * \\
*\end{array}$ & $\begin{array}{l}0,54 \\
1\end{array}$ & $\begin{array}{l}0,08 \\
8\end{array}$ & $\begin{array}{l}* * \\
*\end{array}$ & $\begin{array}{l}0,54 \\
3\end{array}$ & $\begin{array}{l}0,09 \\
4\end{array}$ & \begin{tabular}{|l|}
$* *$ \\
$*$
\end{tabular} & $\begin{array}{l}0,55 \\
7\end{array}$ & $\begin{array}{l}0,09 \\
3\end{array}$ & $\begin{array}{l}* * \\
*\end{array}$ \\
\hline Change in GDP ${ }^{c}$ & $\begin{array}{l}0,01 \\
8\end{array}$ & $\begin{array}{l}0,01 \\
2\end{array}$ & & $\begin{array}{l}0,01 \\
7\end{array}$ & $\begin{array}{l}0,01 \\
4\end{array}$ & & $\begin{array}{l}0,01 \\
8\end{array}$ & \begin{tabular}{|l|}
0,01 \\
5
\end{tabular} & & $\begin{array}{l}0,01 \\
8\end{array}$ & \begin{tabular}{|l}
0,01 \\
2
\end{tabular} & & $\begin{array}{l}0,02 \\
2\end{array}$ & $\begin{array}{l}0,01 \\
5\end{array}$ & & $\begin{array}{l}0,01 \\
8\end{array}$ & \begin{tabular}{|l}
0,01 \\
2
\end{tabular} & & \begin{tabular}{|l|}
0,01 \\
8
\end{tabular} & $\begin{array}{l}0,01 \\
2\end{array}$ & 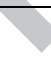 & $\begin{array}{l}0,01 \\
6\end{array}$ & $\begin{array}{l}0,01 \\
2\end{array}$ & & $\begin{array}{l}0,01 \\
7\end{array}$ & $\begin{array}{l}0,01 \\
2\end{array}$ & & $\begin{array}{l}0,01 \\
8\end{array}$ & $\begin{array}{l}0,01 \\
2\end{array}$ & \\
\hline Change in unemployment ${ }^{c}$ & $\begin{array}{l}0,03 \\
9 \\
\end{array}$ & \begin{tabular}{|l|l}
0,01 \\
8 \\
\end{tabular} & * & $\begin{array}{l}0,04 \\
1 \\
\end{array}$ & \begin{tabular}{|l|}
0,01 \\
8 \\
\end{tabular} & * & $\begin{array}{l}0,04 \\
0 \\
\end{array}$ & \begin{tabular}{|l|}
0,01 \\
9 \\
\end{tabular} & * & $\begin{array}{l}0,03 \\
7 \\
\end{array}$ & \begin{tabular}{|l|}
0,01 \\
8 \\
\end{tabular} & * & \begin{tabular}{|l|l}
0,03 \\
7 \\
\end{tabular} & \begin{tabular}{|l}
0,01 \\
8 \\
\end{tabular} & * & $\begin{array}{l}0,03 \\
8 \\
\end{array}$ & $\begin{array}{l}0,01 \\
9 \\
\end{array}$ & * & $\begin{array}{l}0,03 \\
8 \\
\end{array}$ & $\begin{array}{l}0,01 \\
9\end{array}$ & * & $\begin{array}{l}0,03 \\
6 \\
\end{array}$ & $\begin{array}{l}0,01 \\
9\end{array}$ & & $\begin{array}{l}0,03 \\
2\end{array}$ & $\begin{array}{l}0,01 \\
6\end{array}$ & * & $\begin{array}{l}0,03 \\
8\end{array}$ & $\begin{array}{l}0,01 \\
8\end{array}$ & * \\
\hline Individual variables & & & & & & & & & & & & & & & & & & & 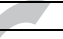 & 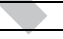 & & & & & & & & & & \\
\hline Age (ref. 35-49y) & & & & & & & & & & & & & & & & & & & & & & & & & & & & & & \\
\hline $20-34 y$ & $\begin{array}{l}0,73 \\
2\end{array}$ & $\begin{array}{l}0,06 \\
4\end{array}$ & $\begin{array}{l}* * \\
*\end{array}$ & $\begin{array}{l}0,69 \\
1\end{array}$ & \begin{tabular}{|l|l}
0,06 \\
4
\end{tabular} & \begin{tabular}{|l|}
$* * *$ \\
$*$
\end{tabular} & $\begin{array}{l}0,73 \\
0\end{array}$ & \begin{tabular}{|l|}
0,06 \\
4
\end{tabular} & $\begin{array}{l}* * \\
*\end{array}$ & $\begin{array}{l}0,70 \\
1\end{array}$ & \begin{tabular}{|l|}
0,06 \\
3
\end{tabular} & $\begin{array}{l}* * \\
*\end{array}$ & $\begin{array}{l}0,68 \\
5\end{array}$ & \begin{tabular}{|l|}
0,06 \\
5
\end{tabular} & $\begin{array}{l}* * \\
*\end{array}$ & $\begin{array}{l}0,72 \\
2\end{array}$ & \begin{tabular}{|l|}
0,06 \\
4
\end{tabular} & \begin{tabular}{|l|}
$* * *$ \\
$*$ \\
$*$
\end{tabular} & $\begin{array}{l}0,68 \\
5\end{array}$ & $\begin{array}{l}0,06 \\
3\end{array}$ & $\begin{array}{l}* * \\
*\end{array}$ & $\begin{array}{l}0,68 \\
0\end{array}$ & $\begin{array}{l}0,06 \\
3\end{array}$ & $\begin{array}{l}* * \\
*\end{array}$ & $\begin{array}{l}0,69 \\
7\end{array}$ & $\begin{array}{l}0,06 \\
4\end{array}$ & \begin{tabular}{|l|}
$* * *$ \\
$*$
\end{tabular} & $\begin{array}{l}0,72 \\
0\end{array}$ & $\begin{array}{l}0,06 \\
4\end{array}$ & $\begin{array}{l}* * \\
*\end{array}$ \\
\hline $50-64 y$ & $\begin{array}{l} \\
0,06 \\
1\end{array}$ & \begin{tabular}{|l|l}
0,06 \\
0
\end{tabular} & & $\begin{array}{l}0,12 \\
9 \\
\end{array}$ & \begin{tabular}{|l}
0,06 \\
2
\end{tabular} & * & $\begin{array}{l}0,07 \\
3 \\
\end{array}$ & \begin{tabular}{|l|l}
0,06 \\
1
\end{tabular} & & $\begin{array}{l}0,06 \\
3 \\
\end{array}$ & \begin{tabular}{|l|}
0,06 \\
0
\end{tabular} & & \begin{tabular}{|l|}
0,04 \\
6 \\
\end{tabular} & \begin{tabular}{|l|}
0,06 \\
2
\end{tabular} & & $\begin{array}{l}0,04 \\
6 \\
\end{array}$ & 0,06 & & \begin{tabular}{|l|} 
\\
0,08 \\
1 \\
\end{tabular} & $\begin{array}{l}0,06 \\
0\end{array}$ & & $\begin{array}{l}0,01 \\
7 \\
\end{array}$ & $\begin{array}{l}0,06 \\
0\end{array}$ & & \begin{tabular}{|l|}
0,06 \\
4 \\
\end{tabular} & $\begin{array}{l}0,06 \\
1\end{array}$ & & $\begin{array}{l}0,05 \\
9 \\
\end{array}$ & $\begin{array}{l}0,06 \\
0\end{array}$ & \\
\hline Employment status (ref. unemployed) & & & & & & & & & & & & & & & & & & & & & & & & & & & & & & \\
\hline Non-employed & $\begin{array}{l}-\overline{0} \\
0,54 \\
8\end{array}$ & \begin{tabular}{|l|l|}
0,10 \\
7
\end{tabular} & $\begin{array}{l}* * \\
*\end{array}$ & $\begin{array}{l}- \\
0,50 \\
7\end{array}$ & \begin{tabular}{|l|}
0,10 \\
8
\end{tabular} & $\begin{array}{l}* * \\
*\end{array}$ & $\begin{array}{l}- \\
0,55 \\
2\end{array}$ & \begin{tabular}{|l|l|}
0,10 \\
6
\end{tabular} & $\begin{array}{l}* * \\
*\end{array}$ & $\begin{array}{l}0,55 \\
0\end{array}$ & \begin{tabular}{|l|l|}
0,10 \\
5
\end{tabular} & $\begin{array}{l}* * \\
*\end{array}$ & $\begin{array}{l}0,60 \\
8\end{array}$ & \begin{tabular}{|l}
0,11 \\
2
\end{tabular} & $\begin{array}{l}* * \\
* \\
*\end{array}$ & 0,57 & \begin{tabular}{|l|l|}
0,10 \\
6
\end{tabular} & \begin{tabular}{|l|}
$* *$ \\
$*$
\end{tabular} & $\begin{array}{l}0,57 \\
3\end{array}$ & $\begin{array}{l}0,10 \\
5\end{array}$ & $\begin{array}{l}* * \\
*\end{array}$ & \begin{tabular}{|l} 
\\
0,54 \\
8
\end{tabular} & $\begin{array}{l}0,10 \\
5\end{array}$ & $\begin{array}{l}* * \\
*\end{array}$ & $\begin{array}{l}0,61 \\
0\end{array}$ & $\begin{array}{l}0,10 \\
8\end{array}$ & \begin{tabular}{|l|}
$* *$ \\
$* *$
\end{tabular} & $\begin{array}{l}0,54 \\
5\end{array}$ & $\begin{array}{l}0,10 \\
7\end{array}$ & $\begin{array}{l}* * \\
*\end{array}$ \\
\hline Employed & $\begin{array}{l}1,59 \\
8 \\
\end{array}$ & \begin{tabular}{|l|}
0,10 \\
1
\end{tabular} & $\begin{array}{l}* * \\
*\end{array}$ & $\begin{array}{l}1,51 \\
6\end{array}$ & \begin{tabular}{|l|l|}
0,10 \\
2
\end{tabular} & $\begin{array}{l}* * \\
*\end{array}$ & $\begin{array}{l} \\
1,57 \\
1\end{array}$ & \begin{tabular}{|l|}
0,10 \\
0
\end{tabular} & $\begin{array}{l}* * \\
* *\end{array}$ & $\begin{array}{l}1,59 \\
4\end{array}$ & \begin{tabular}{|l|}
0,09 \\
9
\end{tabular} & $\begin{array}{l}* * \\
*\end{array}$ & \begin{tabular}{|l|}
1,70 \\
8 \\
\end{tabular} & \begin{tabular}{|l|}
0,10 \\
6
\end{tabular} & *** & \begin{tabular}{|l|}
1,62 \\
3 \\
\end{tabular} & \begin{tabular}{|l|}
0,10 \\
0
\end{tabular} & \begin{tabular}{|l|l|}
$* * *$ \\
$* *$
\end{tabular} & \begin{tabular}{|l|}
1,60 \\
8 \\
\end{tabular} & $\begin{array}{l}0,09 \\
9\end{array}$ & $\begin{array}{l}\text { ** } \\
*\end{array}$ & \begin{tabular}{|l|}
1,57 \\
8 \\
\end{tabular} & $\begin{array}{l}0,09 \\
9\end{array}$ & $\begin{array}{l}{ }^{* * *} \\
*\end{array}$ & \begin{tabular}{|l|}
1,66 \\
8 \\
\end{tabular} & $\begin{array}{l}0,10 \\
2\end{array}$ & \begin{tabular}{|l|}
$* *$ \\
$*$
\end{tabular} & $\begin{array}{l}1,61 \\
5\end{array}$ & $\begin{array}{l}0,10 \\
1\end{array}$ & $\begin{array}{l}* * * \\
*\end{array}$ \\
\hline Type of contract (ref,unlimited) & & & & & & & & & & & & & & & & & & & & & & & & & & & & & & \\
\hline $\mathrm{x}$ limited & $\begin{array}{l}0,50 \\
4\end{array}$ & \begin{tabular}{|l|l}
0,08 \\
9
\end{tabular} & $\begin{array}{l}* * \\
* \\
*\end{array}$ & $\begin{array}{l}0,50 \\
9\end{array}$ & \begin{tabular}{|l|l}
0,08 \\
7
\end{tabular} & $\begin{array}{ll}* * \\
*\end{array}$ & $\begin{array}{l}0,49 \\
9\end{array}$ & \begin{tabular}{|l|l}
0,09 \\
2 \\
\end{tabular} & $\begin{array}{l}* * \\
*\end{array}$ & $\begin{array}{l}0,50 \\
4\end{array}$ & \begin{tabular}{|l|}
0,08 \\
9 \\
\end{tabular} & $\begin{array}{l}* * \\
* \\
\end{array}$ & \begin{tabular}{|l|}
0,51 \\
2 \\
\end{tabular} & \begin{tabular}{|l|l}
0,08 \\
7
\end{tabular} & $\begin{array}{l}* * \\
*\end{array}$ & $\begin{array}{l}0,49 \\
9\end{array}$ & $\begin{array}{l}0,09 \\
0\end{array}$ & \begin{tabular}{|l|}
$* * *$ \\
$*$ \\
\end{tabular} & $\begin{array}{l}0,49 \\
7\end{array}$ & $\begin{array}{l}0,09 \\
0\end{array}$ & $\begin{array}{l}* * \\
* \\
\end{array}$ & \begin{tabular}{|l|}
0,50 \\
7 \\
\end{tabular} & $\begin{array}{l}0,09 \\
1\end{array}$ & $\begin{array}{l}* * \\
* \\
\end{array}$ & $\begin{array}{l}0,50 \\
9\end{array}$ & $\begin{array}{l}0,08 \\
9\end{array}$ & \begin{tabular}{|l|l}
$* * *$ \\
$*$
\end{tabular} & $\begin{array}{l}0,51 \\
0\end{array}$ & $\begin{array}{l}0,09 \\
0\end{array}$ & $\begin{array}{l}* * * \\
*\end{array}$ \\
\hline $\mathrm{x}$ no contraxt & $\begin{array}{l}0,33 \\
7\end{array}$ & $\begin{array}{l}0,13 \\
7\end{array}$ & * & $\begin{array}{l}0,31 \\
9\end{array}$ & \begin{tabular}{|l}
0,13 \\
8
\end{tabular} & * & $\begin{array}{l}0,31 \\
5\end{array}$ & $\begin{array}{l}0,13 \\
7\end{array}$ & * & $\begin{array}{l}0,38 \\
9\end{array}$ & \begin{tabular}{|l}
0,14 \\
9
\end{tabular} & *** & $\begin{array}{l}0,32 \\
9\end{array}$ & $\begin{array}{l}0,13 \\
7\end{array}$ & * & $\begin{array}{l}0,33 \\
8\end{array}$ & $\begin{array}{l}0,14 \\
0\end{array}$ & * & $\begin{array}{l}0,31 \\
1\end{array}$ & $\begin{array}{l}0,13 \\
7\end{array}$ & * & \begin{tabular}{|l|l|}
0,34 \\
8
\end{tabular} & $\begin{array}{l}0,13 \\
6\end{array}$ & * & $\begin{array}{l}0,31 \\
8\end{array}$ & $\begin{array}{l}0,13 \\
7\end{array}$ & $*$ & $\begin{array}{l}0,32 \\
2\end{array}$ & $\begin{array}{l}0,13 \\
7\end{array}$ & * \\
\hline $\mathrm{x}$ self-employed & $\begin{array}{l}0,03 \\
9 \\
\end{array}$ & \begin{tabular}{|l|}
0,07 \\
5 \\
\end{tabular} & & $\begin{array}{l}0,04 \\
6 \\
\end{array}$ & \begin{tabular}{|l|l}
0,07 \\
6 \\
\end{tabular} & & $\begin{array}{l}0,04 \\
9 \\
\end{array}$ & \begin{tabular}{|l|l}
0,07 \\
6 \\
\end{tabular} & & $\begin{array}{l}0,05 \\
5 \\
\end{array}$ & \begin{tabular}{|l}
0,07 \\
4 \\
\end{tabular} & & $\begin{array}{l}0,06 \\
4 \\
\end{array}$ & \begin{tabular}{|l}
0,07 \\
7 \\
\end{tabular} & & $\begin{array}{l}0,05 \\
0 \\
\end{array}$ & \begin{tabular}{|l|l}
0,07 \\
5 \\
\end{tabular} & & \begin{tabular}{|l|l}
0,05 \\
5 \\
\end{tabular} & $\begin{array}{l}0,07 \\
5 \\
\end{array}$ & & \begin{tabular}{|l|}
0,04 \\
0 \\
\end{tabular} & $\begin{array}{l}0,07 \\
5 \\
\end{array}$ & & $\begin{array}{l}0,02 \\
3 \\
\end{array}$ & $\begin{array}{l}0,07 \\
6 \\
\end{array}$ & & $\begin{array}{l}0,03 \\
0 \\
\end{array}$ & $\begin{array}{l}0,07 \\
5 \\
\end{array}$ & \\
\hline Work hours (ref, fulltime) & & & & & & & & & & & & & & & & & & & & & & & & & & & & & & \\
\hline $\mathrm{x}$ marginal part time & $\begin{array}{l}0,22 \\
7 \\
\end{array}$ & \begin{tabular}{|l}
0,24 \\
7
\end{tabular} & & $\begin{array}{l}0,14 \\
7 \\
\end{array}$ & \begin{tabular}{|l|l}
0,24 \\
5
\end{tabular} & & $\begin{array}{l}0,17 \\
3 \\
\end{array}$ & \begin{tabular}{|l|}
0,24 \\
8
\end{tabular} & & $\begin{array}{l}0,15 \\
6 \\
\end{array}$ & \begin{tabular}{|l}
0,24 \\
0
\end{tabular} & & $\begin{array}{l}0,00 \\
4\end{array}$ & \begin{tabular}{|l|}
0,26 \\
0
\end{tabular} & & $\begin{array}{l}0,11 \\
2\end{array}$ & $\begin{array}{l}0,24 \\
4\end{array}$ & & $\begin{array}{l}0,11 \\
9 \\
\end{array}$ & $\begin{array}{l}0,23 \\
9\end{array}$ & & \begin{tabular}{|l}
0,14 \\
7 \\
\end{tabular} & $\begin{array}{l}0,23 \\
7\end{array}$ & & $\begin{array}{l}0,16 \\
6 \\
\end{array}$ & $\begin{array}{l}0,24 \\
3\end{array}$ & & $\begin{array}{l}0,10 \\
9 \\
\end{array}$ & $\begin{array}{l}0,25 \\
0\end{array}$ & \\
\hline $\mathrm{x}$ substantial part time & $\begin{array}{l}0,34 \\
4\end{array}$ & \begin{tabular}{|l|l|}
0,13 \\
3 \\
\end{tabular} & * & $\begin{array}{l}0,22 \\
2 \\
\end{array}$ & \begin{tabular}{|l|}
0,11 \\
2 \\
\end{tabular} & * & $\begin{array}{l}0,25 \\
3 \\
\end{array}$ & \begin{tabular}{|l|}
0,12 \\
7 \\
\end{tabular} & $*$ & $\begin{array}{l}0,32 \\
1\end{array}$ & \begin{tabular}{|l|}
0,12 \\
9 \\
\end{tabular} & * & \begin{tabular}{|l|}
0,31 \\
5 \\
\end{tabular} & \begin{tabular}{|l}
0,13 \\
7 \\
\end{tabular} & $*$ & $\begin{array}{l}0,31 \\
6 \\
\end{array}$ & \begin{tabular}{|l|l}
0,13 \\
1 \\
\end{tabular} & * & \begin{tabular}{|l|}
0,30 \\
5 \\
\end{tabular} & $\begin{array}{l}0,13 \\
0 \\
\end{array}$ & * & \begin{tabular}{|l|}
0,32 \\
0 \\
\end{tabular} & $\begin{array}{l}0,12 \\
9 \\
\end{array}$ & * & \begin{tabular}{|l|}
0,32 \\
3 \\
\end{tabular} & $\begin{array}{l}0,13 \\
4 \\
\end{array}$ & * & $\begin{array}{l}0,36 \\
2 \\
\end{array}$ & $\begin{array}{l}0,13 \\
2\end{array}$ & *** \\
\hline Cross-level interactions & & & & & & & & & & & & & & & & & & & & & & & & & & & & & & \\
\hline $\begin{array}{l}\text { Non-employed } x \text { change in } \\
\text { unemployment }\end{array}$ & $\begin{array}{l}0,02 \\
1\end{array}$ & $\begin{array}{l}0,01 \\
9\end{array}$ & & $\begin{array}{l}0,01 \\
6\end{array}$ & $\begin{array}{l}0,01 \\
9\end{array}$ & & $\begin{array}{l}0,02 \\
1\end{array}$ & $\begin{array}{l}0,01 \\
9\end{array}$ & & $\begin{array}{l}0,02 \\
2\end{array}$ & $\begin{array}{l}0,01 \\
9\end{array}$ & & $\begin{array}{l}0,02 \\
4\end{array}$ & \begin{tabular}{|l}
0,02 \\
0
\end{tabular} & & $\begin{array}{l}0,02 \\
1\end{array}$ & $\begin{array}{l}0,01 \\
9\end{array}$ & & $\begin{array}{l}0,01 \\
8\end{array}$ & $\begin{array}{l}0,01 \\
9\end{array}$ & & \begin{tabular}{|l}
0,03 \\
0
\end{tabular} & $\begin{array}{l}0,02 \\
3\end{array}$ & & $\begin{array}{l}0,02 \\
6\end{array}$ & $\begin{array}{l}0,02 \\
0\end{array}$ & & $\begin{array}{l}0,02 \\
1\end{array}$ & $\begin{array}{l}0,01 \\
9\end{array}$ & \\
\hline Employed $x$ change in u nemployment & $\begin{array}{l}- \\
0,00 \\
6\end{array}$ & \begin{tabular}{|l|}
0,01 \\
6
\end{tabular} & & $\begin{array}{l}0,01 \\
0\end{array}$ & \begin{tabular}{|l|}
0,01 \\
6
\end{tabular} & & $\begin{array}{l}0,00 \\
9\end{array}$ & \begin{tabular}{|l|l|}
0,01 \\
6
\end{tabular} & $>$ & $\begin{array}{l}0,00 \\
7\end{array}$ & \begin{tabular}{|l|}
0,01 \\
6
\end{tabular} & & $\begin{array}{l}0,00 \\
8\end{array}$ & \begin{tabular}{|l|}
0,01 \\
7
\end{tabular} & & $\begin{array}{l}0,00 \\
7\end{array}$ & $\begin{array}{l}0,01 \\
6\end{array}$ & & $\begin{array}{l}0,00 \\
6\end{array}$ & $\begin{array}{l}0,01 \\
6\end{array}$ & & \begin{tabular}{|l}
0,02 \\
3
\end{tabular} & $\begin{array}{l}0,02 \\
0\end{array}$ & & $\begin{array}{l}0,00 \\
1\end{array}$ & $\begin{array}{l}0,01 \\
6\end{array}$ & & $\begin{array}{l}0,00 \\
6\end{array}$ & $\begin{array}{l}0,01 \\
6\end{array}$ & \\
\hline $\begin{array}{l}\mathrm{x} \text { marginal part time } \mathrm{x} \text { change in } \\
\text { unemployment }\end{array}$ & $\begin{array}{l}0,09 \\
8\end{array}$ & \begin{tabular}{|l|}
0,04 \\
9 \\
\end{tabular} & $*$ & $\begin{array}{l}0,08 \\
5\end{array}$ & \begin{tabular}{|l|l|}
0,04 \\
3 \\
\end{tabular} & * & $\begin{array}{l}0,09 \\
2\end{array}$ & \begin{tabular}{|l|}
0,04 \\
5 \\
\end{tabular} & $*$ & $\begin{array}{l}0,09 \\
2 \\
\end{array}$ & \begin{tabular}{|l|}
0,04 \\
5 \\
\end{tabular} & * & \begin{tabular}{|l|}
0,07 \\
5 \\
\end{tabular} & \begin{tabular}{|l|}
0,04 \\
0 \\
\end{tabular} & & $\begin{array}{l}0,09 \\
4 \\
\end{array}$ & \begin{tabular}{|l|l|}
0,04 \\
5
\end{tabular} & * & $\begin{array}{l}0,09 \\
4 \\
\end{array}$ & $\begin{array}{l}0,04 \\
5 \\
\end{array}$ & * & \begin{tabular}{|l|}
0,11 \\
8 \\
\end{tabular} & $\begin{array}{l}0,05 \\
9\end{array}$ & * & $\begin{array}{l}0,09 \\
3 \\
\end{array}$ & $\begin{array}{l}0,04 \\
5\end{array}$ & * & $\begin{array}{l}0,08 \\
7 \\
\end{array}$ & $\begin{array}{l}0,04 \\
7 \\
\end{array}$ & \\
\hline $\begin{array}{l}x \text { substantial part time } x \text { change in } \\
\text { unemployment }\end{array}$ & $\begin{array}{l}0,03 \\
6\end{array}$ & \begin{tabular}{|l|}
0,03 \\
2
\end{tabular} & & $\begin{array}{l}0,04 \\
0\end{array}$ & \begin{tabular}{|l|}
0,03 \\
2
\end{tabular} & E & $\begin{array}{l}2,04 \\
3\end{array}$ & \begin{tabular}{|l|}
0,03 \\
2
\end{tabular} & & $\begin{array}{l}2,04 \\
2\end{array}$ & \begin{tabular}{|l|}
0,03 \\
2
\end{tabular} & & \begin{tabular}{|l|}
0,03 \\
8
\end{tabular} & \begin{tabular}{|l|}
0,03 \\
4
\end{tabular} & & $\begin{array}{l} \\
0,04 \\
2\end{array}$ & \begin{tabular}{|l|}
0,03 \\
3
\end{tabular} & & \begin{tabular}{|l|}
0,03 \\
7
\end{tabular} & $\begin{array}{l}0,03 \\
2\end{array}$ & & \begin{tabular}{|l|l|}
0,05 \\
9
\end{tabular} & $\begin{array}{l}0,03 \\
5\end{array}$ & & $\begin{array}{l}0,03 \\
7\end{array}$ & $\begin{array}{l}0,03 \\
3\end{array}$ & & $\begin{array}{l}0,03 \\
5\end{array}$ & $\begin{array}{l}0,03 \\
2\end{array}$ & \\
\hline Variance (3) Country & $\begin{array}{l}0,32 \\
0\end{array}$ & $\begin{array}{l}0,10 \\
9\end{array}$ & *** & $\begin{array}{l}0,32 \\
2\end{array}$ & $\begin{array}{l}0,11 \\
1\end{array}$ & *** & $\begin{array}{l}0,31 \\
7\end{array}$ & \begin{tabular}{|l|}
0,10 \\
9
\end{tabular} & *** & $\begin{array}{l}0,27 \\
9\end{array}$ & \begin{tabular}{|l|}
0,09 \\
6 \\
\end{tabular} & *** & $\begin{array}{l}0,30 \\
4\end{array}$ & \begin{tabular}{|l|}
0,10 \\
4
\end{tabular} & $*_{* *}$ & $\begin{array}{l}0,31 \\
9 \\
\end{array}$ & \begin{tabular}{|l|}
0,11 \\
0 \\
\end{tabular} & *** & \begin{tabular}{|l|}
0,31 \\
4 \\
\end{tabular} & $\begin{array}{l}0,10 \\
8 \\
\end{array}$ & $* *$ & \begin{tabular}{|l|}
0,31 \\
3 \\
\end{tabular} & $\begin{array}{l}0,10 \\
7\end{array}$ & *** & \begin{tabular}{|l|}
0,31 \\
1 \\
\end{tabular} & $\begin{array}{l}0,10 \\
7 \\
\end{array}$ & *** & $\begin{array}{l}0,31 \\
6 \\
\end{array}$ & $\begin{array}{l}0,10 \\
9\end{array}$ & ** \\
\hline (2) Period & $\begin{array}{l}0,01 \\
1 \\
\end{array}$ & \begin{tabular}{|l|}
0,01 \\
0 \\
\end{tabular} & & $\begin{array}{l}0,01 \\
2 \\
\end{array}$ & \begin{tabular}{|l|}
0,01 \\
1
\end{tabular} & 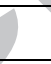 & $\begin{array}{ll}0,01 \\
5 \\
\end{array}$ & \begin{tabular}{|l|}
0,01 \\
2 \\
\end{tabular} & & $\begin{array}{l}0,01 \\
4 \\
\end{array}$ & \begin{tabular}{|l|}
0,01 \\
1 \\
\end{tabular} & & \begin{tabular}{|l|}
0,00 \\
9 \\
\end{tabular} & \begin{tabular}{|l}
0,01 \\
0 \\
\end{tabular} & & $\begin{array}{l}0,01 \\
4 \\
\end{array}$ & \begin{tabular}{|l|}
0,01 \\
1 \\
\end{tabular} & & \begin{tabular}{|l|}
0,01 \\
6 \\
\end{tabular} & $\begin{array}{l}0,01 \\
2 \\
\end{array}$ & & \begin{tabular}{|l|}
0,01 \\
2 \\
\end{tabular} & $\begin{array}{l}0,01 \\
1 \\
\end{array}$ & & \begin{tabular}{|l|}
0,01 \\
5 \\
\end{tabular} & $\begin{array}{l}0,01 \\
2 \\
\end{array}$ & & $\begin{array}{l}0,01 \\
4 \\
\end{array}$ & $\begin{array}{l}0,01 \\
1 \\
\end{array}$ & 39 \\
\hline (1) Individual & $\begin{array}{l}12,4 \\
93\end{array}$ & \begin{tabular}{|l|}
0,11 \\
6 \\
\end{tabular} & $\begin{array}{l}* * \\
*\end{array}$ & $\begin{array}{l}12,3 \\
86\end{array}$ & \begin{tabular}{|l|}
0,11 \\
7
\end{tabular} & $\begin{array}{l}* * \\
*\end{array}$ & $\begin{array}{l}12,6 \\
02\end{array}$ & \begin{tabular}{|l|}
0,11 \\
7
\end{tabular} & $\begin{array}{l}* * \\
*\end{array}$ & $\begin{array}{l}12,5 \\
03\end{array}$ & \begin{tabular}{|l|}
0,11 \\
5
\end{tabular} & $\begin{array}{l}* * \\
*\end{array}$ & \begin{tabular}{|l|}
12,6 \\
33
\end{tabular} & \begin{tabular}{|l|l|}
0,12 \\
0
\end{tabular} & $\begin{array}{l}* * \\
*\end{array}$ & $\begin{array}{l}12,6 \\
61\end{array}$ & \begin{tabular}{|l|}
0,11 \\
7
\end{tabular} & \begin{tabular}{|l|}
$* *$ \\
$* *$
\end{tabular} & $\begin{array}{l}12,4 \\
29\end{array}$ & $\begin{array}{l}0,11 \\
6\end{array}$ & $\begin{array}{l}* * \\
*\end{array}$ & \begin{tabular}{|l|}
12,3 \\
68 \\
\end{tabular} & $\begin{array}{l}0,11 \\
5\end{array}$ & $\begin{array}{l}* * \\
*\end{array}$ & $\begin{array}{l}12,7 \\
30\end{array}$ & $\begin{array}{l}0,11 \\
9\end{array}$ & \begin{tabular}{|l|}
$* *$ \\
$* *$
\end{tabular} & $\begin{array}{l}12,4 \\
25\end{array}$ & $\begin{array}{l}0,11 \\
6\end{array}$ & $\begin{array}{l}* * * \\
*\end{array}$ \\
\hline
\end{tabular}


ACCEPTED MANUSCRIPT

\begin{tabular}{|c|c|c|c|c|c|c|c|c|c|c|}
\hline$\rho$ & $\begin{array}{l}0,02 \\
6\end{array}$ & $\begin{array}{l}0,02 \\
6\end{array}$ & $\begin{array}{l}0,02 \\
6\end{array}$ & $\begin{array}{l}0,02 \\
3\end{array}$ & $\begin{array}{l}0,02 \\
4\end{array}$ & $\begin{array}{l}0,02 \\
6\end{array}$ & $\begin{array}{l}0,02 \\
6\end{array}$ & \multirow{3}{*}{\begin{tabular}{l|l}
6 & \\
123572695 \\
\end{tabular}} & $\begin{array}{l}0,02 \\
5\end{array}$ & $\begin{array}{l}0,02 \\
6\end{array}$ \\
\hline$-2 \mathrm{LL}$ & 12403 & 1198 & 12494 & 127 & 1201 & 1252 & 1242 & & \multirow[t]{2}{*}{123195776} & 123557962 \\
\hline$\frac{*}{*} \mathrm{p}<, 0$ & ndividua & wome & $\mathrm{d}\left({ }^{*} \mathrm{col}\right.$ & try $=$ & & & & & & \\
\hline
\end{tabular}

Appendix 3_A: Jackknife analysis, the results of Model 4 of Table 3 for men, each time without one country (Part 1) 
Appendix 3_B: Jackknife analysis, the results of Model 4 of Table 3 for men, each time without one country (Part 2)

\begin{tabular}{|c|c|c|c|c|c|c|c|c|c|c|c|c|c|c|c|c|c|c|c|c|c|c|c|c|c|c|c|c|c|c|}
\hline \multirow[t]{2}{*}{ Without } & \multirow{2}{*}{\multicolumn{3}{|c|}{ UK }} & \multicolumn{3}{|c|}{ Hungary } & \multicolumn{3}{|c|}{ Ireland } & \multicolumn{3}{|c|}{ Netherland } & \multicolumn{3}{|c|}{ Norway } & \multicolumn{3}{|c|}{ Poland } & \multicolumn{3}{|c|}{ Portugal } & \multicolumn{3}{|c|}{ Sweden } & \multicolumn{3}{|c|}{ Slovakia } & \multicolumn{3}{|c|}{ Slovenia } \\
\hline & & & sig, & b & $\mathrm{SE}$ & sig, & b & $\mathrm{SE}$ & sig, & $\mathrm{b}$ & SE & sig, & $\mathrm{b}$ & $\mathrm{SE}$ & sig, & b & SE & sig, & $\mathrm{b}$ & SE & sig, & & SE & sig, & b & $\mathrm{SE}$ & sig, & $b^{2}$ & SE & sig, \\
\hline \multirow{2}{*}{\multicolumn{31}{|c|}{ 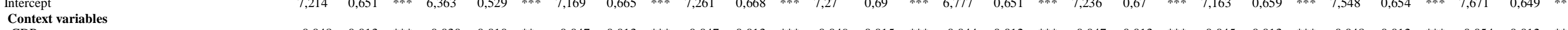 }} \\
\hline & & & & & & & & & & & & & & & & & & & & & & & & & & & & & & \\
\hline & $-0,048$ & 0,013 & $* * *$ & $-0,030$ & 0,010 & $* *$ & $-0,047$ & 0,013 & $* * * *$ & $-0,047$ & 0,013 & $* * *$ & $-0,049$ & 0,015 & $* * *$ & $-0,044$ & 0,012 & $* * *$ & $-0,047$ & 0,013 & *** & $-0,045$ & 0,013 & $* * *$ & $-0,048$ & 0,012 & $* * *$ & $-0,054$ & 0,012 & $* * *$ \\
\hline \multirow{2}{*}{\multicolumn{31}{|c|}{ Period variables }} \\
\hline & & & & & & & & & & & & & & & & & & & & & & & & & & & & & & \\
\hline $\begin{array}{l}\text { Period (ref, 2006) } \\
2012\end{array}$ & $-0,578$ & 0,0 & **** & $-0,521$ & 0,090 & $* * * *$ & $-0,542$ & 0,093 & ${ }^{* * * *}$ & $-0,562$ & 0,091 & **** & $-0,5$ & 0,097 & **** & $-0,477$ & 0,098 & **** & $-0,550$ & 0,094 & $* * *$ & $-0,551$ & 0,093 & $* * *$ & $-0,529$ & 0,092 & $* * *$ & $-0,487$ & 0,074 & **** \\
\hline Change in GDP ${ }^{c}$ & 0,022 & 0,013 & & 0,016 & 0,012 & & 0,018 & 0,012 & & 0,018 & 0,012 & & 0,019 & 0,015 & & 0,012 & 0,012 & & 0,018 & 0,012 & & 0,017 & 0,012 & & 0,017 & 0,012 & & 0,015 & 0,010 & \\
\hline \multirow{2}{*}{\multicolumn{31}{|c|}{$\begin{array}{l}\text { Individual variables } \\
\text { Age (ref } 35-49 \mathrm{y})\end{array}$}} \\
\hline & & & & & & & & & & & & & & & & & & & & & & & & & & & & & & \\
\hline $20-34 y$ & $-0,697$ & 0,063 & $* * *$ & $-0,662$ & 0,063 & $* * * *$ & $-0,692$ & 0,064 & $* * *$ & $-0,694$ & 0,064 & $* * * *$ & $-0,746$ & 0,064 & $* * *$ & $-0,656$ & 0,063 & *** & $-0,666$ & 0,063 & & ( & 0,064 & $* * *$ & $-0,674$ & 0,063 & $* * *$ & $-0,715$ & 0,063 & **** \\
\hline $50-64 y$ & $-0,019$ & 0,060 & & $-0,081$ & 0,059 & & $-0,014$ & 0,06 & & $-0,031$ & 0,061 & & $-0,061$ & 0,061 & & $-0,111$ & 0,060 & & $-0,069$ & 0,060 & & $-0,049$ & 0,061 & & $-0,073$ & 0,060 & & $-0,074$ & 0,060 & \\
\hline \multicolumn{31}{|l|}{ Employment status (ref. unemployed) } \\
\hline Non-employed & $-0,622$ & 0,106 & $* * *$ & $-0,589$ & 0,105 & $* * *$ & $-0,556$ & 0,104 & ${ }^{* * * *}$ & $-0,567$ & 0,107 & $* * *$ & $-0,538$ & 0,106 & $* * *$ & $-0,528$ & 0,110 & $* * *$ & $-0,518$ & 0,106 & $* * *$ & $-0,539$ & 0,107 & $* * *$ & $-0,562$ & 0,107 & $* * *$ & $-0,564$ & 0,106 & **** \\
\hline \multirow{2}{*}{\multicolumn{30}{|c|}{ (1, }} & *** \\
\hline & & & & & & & & & & & & & & & & & & & & & & & & & & & *** & & & **** \\
\hline $\begin{array}{l}\mathrm{x} \text { limited } \\
\mathrm{x} \text { no contraxt }\end{array}$ & $\begin{array}{l}0,009 \\
0,291\end{array}$ & 0,143 & $*$ & $0,0,324$ & $\begin{array}{l}0,092 \\
0,134\end{array}$ & $*$ & $\begin{array}{l}0,489 \\
0,425\end{array}$ & $\begin{array}{l}0,085 \\
0,15\end{array}$ & $*$ & $\begin{array}{l}0,507 \\
0,283\end{array}$ & $\begin{array}{l}0,091 \\
0,137\end{array}$ & ${ }_{*}^{* *}$ & $\begin{array}{l}0,506 \\
0,336\end{array}$ & $\begin{array}{l}0,096 \\
0,141\end{array}$ & $*$ & $\begin{array}{l}0,509 \\
0,310\end{array}$ & $\begin{array}{l}0,089 \\
0,136\end{array}$ & $*$ & 0,248 & 0,129 & N & $\begin{array}{l}0,509 \\
0,360\end{array}$ & $\begin{array}{l}0,137 \\
0,137\end{array}$ & $* *$ & $\begin{array}{l}0,503 \\
0,300\end{array}$ & $\begin{array}{l}0,090 \\
0,136\end{array}$ & $*$ & $\begin{array}{l}0,507 \\
0,330\end{array}$ & $\begin{array}{l}0,087 \\
0,137\end{array}$ & $*$ \\
\hline $\mathrm{x}$ self-employed & 0,055 & 0,075 & & 0,073 & 0,074 & & 0,047 & 0,075 & & 0,027 & 0,075 & & 0,058 & 0,076 & & 0,051 & 0,075 & & 0,078 & 0,075 & & 0,064 & 0,076 & & 0,085 & 0,075 & & 0,047 & 0,075 & \\
\hline \multicolumn{31}{|l|}{$\begin{array}{l}\text { X self-employed } \\
\text { Work hours (ref, } f\end{array}$} \\
\hline $\mathrm{x} \operatorname{marg}$ & $-0,189$ & 0,247 & & $-0,158$ & 0,235 & & $-0,198$ & 0,239 & & $-0,179$ & 0,249 & & $-0,189$ & 0,249 & & $-0,164$ & 0,242 & & $-0,101$ & 0,242 & & $-0,268$ & 0,242 & & $-0,141$ & 0,240 & & $-0,166$ & 0,239 & \\
\hline $\mathrm{x}$ substantial part time & 0,265 & 0,130 & * & 0,294 & 0,128 & * & 0,306 & 0,13 & * & 0,294 & 0,139 & * & 0,324 & 0,136 & * & 0,301 & 0,131 & & 0,319 & 0,129 & * & 0,316 & 0,133 & * & 0,318 & 0,129 & * & 0,298 & 0,130 & * \\
\hline \multicolumn{31}{|l|}{ nteractions } \\
\hline Non-employed $x$ change in unemplo & 0,022 & 0,019 & & 0,024 & 0,019 & & 0,013 & 0,025 & & 0,021 & 0,019 & & 0,020 & 0,020 & & 0,020 & 0,018 & & 0,021 & 0,019 & & 0,021 & 0,019 & & 0,021 & 0,019 & & 0,021 & 0,019 & \\
\hline Employ & $-0,007$ & 0,016 & & $-0,005$ & 0,016 & & $-0,012$ & 0,021 & & $-0,009$ & 0,016 & & $-0,009$ & 0,016 & & $-0,009$ & 0,017 & & $-0,001$ & 0,016 & & $-0,007$ & 0,016 & & $-0,002$ & 0,016 & & $-0,005$ & 0,016 & \\
\hline $\mathrm{x}$ marginal part time $\mathrm{x}$ & 0,086 & 0,040 & * & 0,089 & 0,044 & * & 0,072 & 0,038 & & 0,093 & 0,045 & * & 0,094 & 0,046 & & 0,090 & 0,049 & & 0,096 & 0,046 & * & 0,100 & 0,050 & * & 0,092 & 0,045 & * & 0,089 & 0,045 & * \\
\hline $\mathrm{x}$ substantial part time $\mathrm{x}$ & 0,041 & 0,032 & & 0,028 & 0,032 & & 0,029 & 0,05 & & 0,039 & 0,032 & & 0,035 & 0,033 & & 0,033 & 0,034 & & 0,037 & 0,032 & & 0,037 & 0,032 & & 0,038 & 0,032 & & 0,034 & 0,032 & \\
\hline Variance (3) Country & 0,301 & 0,104 & $* *$ & 0,305 & 0,106 & *** & 0,318 & 0,109 & $* *$ & 0,319 & 0,109 & ** & 0,317 & 0,109 & ** & 0,264 & 0,091 & $* *$ & 0,318 & 0,109 & *** & 0,309 & 0,107 & *** & 0,286 & 0,099 & *** & 0,267 & 0,091 & *** \\
\hline (2) Period & 0,015 & 0,011 & & 0,013 & 0,011 & & 0,015 & 0,012 & & 0,013 & 0,011 & & 0,015 & 0,012 & & 0,012 & 0,011 & & 0,015 & 0,012 & & 0,015 & 0,012 & & 0,014 & 0,011 & & 0,002 & 0,007 & \\
\hline (1) Individual & 12,356 & 0,115 & $* * *$ & 12,203 & 0,113 & $* * *$ & 12,341 & 0,115 & $* * * *$ & 12,573 & 0,117 & $* * *$ & 12,712 & 0,119 & **** & 12,317 & 0,115 & $* * *$ & 12,441 & 0,115 & $* * *$ & 12,577 & 0,117 & $* * *$ & 12,467 & 0,116 & **** & 12,578 & 0,116 & ***** \\
\hline & 0,02 & & & $\begin{array}{l}0,025 \\
124346\end{array}$ & & & $\begin{array}{l}0,026 \\
122797\end{array}$ & & & $\begin{array}{l}0,026 \\
124065\end{array}$ & & & $\begin{array}{l}0,025 \\
1239970\end{array}$ & 018 & & 0,022 & & & $\begin{array}{l}0,026 \\
124712\end{array}$ & & & 0,025 & & & 0,023 & & & $\begin{array}{l}0,021 \\
1262\end{array}$ & & \\
\hline
\end{tabular}


ACCEPTED MANUSCRIPT

Appendix 3_C: Jackknife analysis, the results of Model 4 of Table 3 for women, each time without one country (Part 1)

\begin{tabular}{|c|c|c|c|c|c|c|c|c|c|c|c|c|c|c|c|c|c|c|c|c|c|c|c|c|c|c|c|c|c|c|}
\hline \multirow[t]{2}{*}{ Without } & \multirow{2}{*}{\multicolumn{3}{|c|}{$\begin{array}{ll}\text { Belgium } \\
\mathrm{SE}\end{array}$ sig, }} & \multirow{2}{*}{\multicolumn{3}{|c|}{ Bulgaria }} & \multicolumn{3}{|c|}{$\begin{array}{l}\text { Swizz } \\
\end{array}$} & \multirow{2}{*}{\multicolumn{3}{|c|}{$\begin{array}{ll}\begin{array}{l}\text { Cyprus } \\
\text { SE }\end{array} \text { sig. } & \end{array}$}} & \multicolumn{3}{|c|}{ Germany } & \multicolumn{3}{|c|}{ Denmark } & \multicolumn{3}{|c|}{ Estonia } & \multicolumn{3}{|c|}{ Spain } & \multicolumn{3}{|c|}{ Finland } & \multicolumn{3}{|c|}{ France } \\
\hline & & & & & SE & sig, & $\mathrm{b}$ & SE & sig, & & & sig, & b & SE & sig, & b & SE & sig, & b & SE & sig, & b & SE & sig, & b & SE & sig, & b & SE & sig, \\
\hline $\begin{array}{l}\text { Intercept } \\
\text { Context variables }\end{array}$ & 6,306 & 0,403 & $* * * *$ & 6,278 & 0,409 & $* * * *$ & 6,298 & 0,405 & $* * * *$ & 6,420 & 0,441 & $* * * *$ & 6,380 & 0,409 & **** & 6,286 & 0,410 & $* * * *$ & 6,348 & 0,406 & 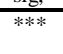 & 6,423 & 0,411 & **** & 6,295 & 0,386 & 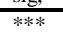 & 6,319 & 0,405 & $\frac{5,4}{* * *}$ \\
\hline GDP & $-0,054$ & 0,012 & $* * *$ & $-0,052$ & 0,013 & $* * *$ & $-0,053$ & 0,012 & $* * *$ & $-0,056$ & 0,013 & $* * *$ & $-0,056$ & 0,012 & $* * *$ & $-0,053$ & 0,012 & $* * *$ & $-0,056$ & 0,012 & **** & $-0,054$ & 0,012 & $* * *$ & $-0,050$ & 0,011 & $* * *$ & $-0,054$ & 0,012 & $* * *$ \\
\hline Unemployment rate & 0,028 & 0,046 & & 0,031 & 0,047 & & 0,031 & 0,046 & & 0,020 & 0,050 & & 0,018 & 0,048 & & 0,030 & 0,047 & & 0,026 & 0,046 & & 0,019 & 0,047 & & 0,038 & 0,044 & & 0,029 & 0,047 & \\
\hline \multicolumn{31}{|l|}{$\begin{array}{l}\text { Period variables } \\
\text { Period (ref, 2006) }\end{array}$} \\
\hline 2012 & $-0,571$ & 0,145 & $* * * *$ & $-0,528$ & 0,138 & **** & $-0,534$ & 0,149 & $* * * *$ & $-0,617$ & 0,129 & $* * *$ & $-0,671$ & 0,138 & $* * *$ & $-0,571$ & 0,141 & $* * * *$ & $-0,573$ & 0,142 & $* * *$ & $-0,556$ & 0,135 & $* * *$ & $-0,564$ & 0,144 & $* * *$ & $-0,573$ & 0,145 & **** \\
\hline Change in $\mathrm{GDP}^{\mathrm{c}}$ & 0,028 & 0,019 & & 0,025 & 0,018 & & 0,016 & 0,024 & & 0,030 & 0,017 & & 0,035 & 0,017 & $*$ & 0,026 & 0,019 & & 0,029 & 0,019 & & 0,023 & 0,018 & & 0,027 & 0,019 & & 0,028 & 0,019 & \\
\hline Change in unemployment ${ }^{\mathrm{c}}$ & 0,045 & 0,027 & & 0,044 & 0,026 & & 0,043 & 0,027 & & 0,042 & 0,025 & & 0,061 & 0,026 & * & 0,043 & 0,026 & & 0,049 & 0,026 & & 0,047 & 0,032 & & 0,043 & 0,027 & & 0,045 & 0,026 & \\
\hline \multicolumn{31}{|l|}{$\begin{array}{l}\text { Individual variables } \\
\text { Age (ref. } 35-49 \mathrm{y} \text { ) }\end{array}$} \\
\hline $20-34 y$ & $-0,632$ & 0,066 & $* * *$ & $-0,584$ & 0,066 & $* * *$ & $-0,647$ & 0,067 & $* * *$ & $-0,596$ & 0,066 & $* * *$ & $-0,610$ & 0,067 & $* * *$ & $-0,592$ & 0,066 & $* * *$ & $-0,610$ & 0,067 & & $-0,588$ & 0,066 & $* * *$ & $-0,610$ & 0,067 & $* * *$ & $-0,577$ & 0,067 & *** \\
\hline $50-64 y$ & 0,115 & 0,060 & * & 0,090 & 0,062 & & 0,111 & 0,062 & & 0,132 & 0,061 & * & 0,128 & 0,063 & * & 0,136 & 0,062 & 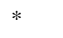 & 0,125 & 0,0 & & 0,130 & 0,062 & 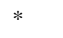 & 0,126 & 0,063 & * & 0,141 & 0,062 & * \\
\hline \multicolumn{31}{|c|}{ 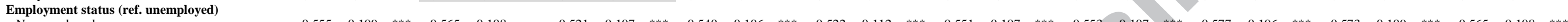 } \\
\hline Non- & $-0,555$ & 0,109 & $* * *$ & $-0,565$ & 0,108 & & $-0,521$ & 0,107 & $* * *$ & $-0,540$ & 0,106 & ***** & -0.522 & 0,112 & $* * *$ & $-0,551$ & 0,107 & $* * *$ & $-0,553$ & 0,107 & $* * *$ & $-0,577$ & 0,106 & $* * *$ & $-0,573$ & 0,109 & $* * *$ & $-0,565$ & 0.108 & *** \\
\hline Employed & $-1,074$ & 0,111 & $* * *$ & $-1,065$ & 0,111 & $* * *$ & $-1,097$ & 0,109 & $* * *$ & $-1,072$ & 0,108 & $* * *$ & $-1,084$ & 0,114 & $* * *$ & $-1,051$ & 0,109 & $* * *$ & $-1,106$ & 0,110 & $* * *$ & $-1,112$ & 0,108 & $* * *$ & $-1,088$ & 0,112 & $* * *$ & $-1,084$ & 0,111 & *** \\
\hline \multicolumn{31}{|l|}{ Type of contract (ref,unlimited ) } \\
\hline $\begin{array}{l}x \text { limited } \\
x \text { no cont }\end{array}$ & $\begin{array}{l}0,408 \\
-0,014\end{array}$ & 0,098 & wan & $\begin{array}{l}0,413 \\
0,011\end{array}$ & $\begin{array}{l}0,098 \\
0,154\end{array}$ & was & $\begin{array}{l}0,453 \\
-0,007\end{array}$ & $\begin{array}{l}0,098 \\
0,156\end{array}$ & Nan & $\begin{array}{l}0,409 \\
0,048\end{array}-10$ & $\begin{array}{l}0,09 l \\
0,170\end{array}$ & s. & $\begin{array}{l}0,400 \\
-0,074\end{array}$ & $\begin{array}{l}0,099 \\
0,156\end{array}$ & $N_{n}$ & $\begin{array}{l}0,403 \\
-0,021\end{array}$ & $\begin{array}{l}0,098 \\
0,156\end{array}$ & & $\begin{array}{l}0,454 \\
-0.002\end{array}$ & $\begin{array}{l}0,099 \\
0,155\end{array}$ & W & $\begin{array}{l}0,432 \\
-0,006\end{array}$ & 0 & ${ }^{* * * *}$ & $\begin{array}{l}0,432 \\
0,002\end{array}$ & 0,101 & ${ }^{* * * * *}$ & $\begin{array}{l}0,423 \\
0.007\end{array}$ & $0,0,098$ & ${ }^{* * * * *}$ \\
\hline $\begin{array}{c}\mathrm{x} \text { no contraxt } \\
\mathrm{x} \text { self-employed }\end{array}$ & $\begin{array}{l}-0,014 \\
-0,200\end{array}$ & 0,116 & & $-0,281$ & 0,114 & $*$ & $-0,247$ & 0,116 & $*$ & $\begin{array}{l}0,048 \\
-0,230\end{array}$ & 0,115 & * & $\begin{array}{l}-0,0 / 4 \\
-0,229\end{array}$ & $\begin{array}{l}0,150 \\
0,117\end{array}$ & * & $\begin{array}{l}-0,021 \\
-0,255\end{array}$ & 0,115 & & $\begin{array}{l}-0,002 \\
-0,216\end{array}$ & 0,106 & * & $\begin{array}{l}-0,000 \\
-0,253\end{array}$ & $\begin{array}{l}0,150 \\
0,117\end{array}$ & * & $\begin{array}{l}0,022 \\
-0,258\end{array}$ & 0,117 & * & $\begin{array}{l}, 0,001 \\
-0,258\end{array}$ & $\begin{array}{l}0,115 \\
0,115\end{array}$ & $*$ \\
\hline \multicolumn{31}{|l|}{ Work hours (ref, fulltime) } \\
\hline $\mathrm{x}$ marginal part time & $-0,099$ & 0,142 & & $-0,134$ & 0,136 & & $-0,134$ & 0,144 & & $-0,146$ & 0,137 & & $-0,118$ & 0,148 & & $-0,139$ & 0,138 & & $-0,079$ & 0,138 & & $-0,129$ & 0,137 & & $-0,142$ & 0,139 & & $-0,171$ & 0,140 & \\
\hline $\mathrm{x}$ substantial part time & 0,022 & 0,087 & & 0,035 & 0,084 & & 0,090 & 0,087 & & 0,032 & 0,084 & & 0,008 & 0,091 & & 0,044 & 0,087 & & 0,023 & 0,085 & & 0,024 & 0,084 & & $-0,011$ & 0,087 & & 0,013 & 0,086 & \\
\hline \multicolumn{31}{|l|}{ Cross- 1} \\
\hline Non-en & 0,001 & 0,021 & & 0,00 & 0,021 & & 0,002 & 0,021 & & 0,00 & 0,021 & & $-0,005$ & 0,0 & & 0,001 & 0,0 & & 0,0 & 0,021 & & $-0,022$ & 0,025 & & 0, & 0,021 & & 0,0 & 0,021 & \\
\hline Emplo & $-0,014$ & 0,021 & & $-0,012$ & 0,021 & & $-0,013$ & 0,021 & & $-0,014$ & 0,021 & & $-0,014$ & 0,022 & & $-0,012$ & 0,021 & & $-0,017$ & 0,021 & & $-0,037$ & 0,026 & & $-0,012$ & 0,021 & & $-0,014$ & 0,021 & \\
\hline$x$ marg & 0,058 & 0,024 & * & 0,059 & 0,030 & * & 0,060 & 0,030 & * & 0,056 & 0,030 & & 0,063 & 0,031 & & 0,0 & 0,027 & * & 0,064 & 0,032 & * & 0,0 & 0,036 & * & 0,060 & 0,030 & * & 0,062 & 0,031 & * \\
\hline $\mathrm{x}$ substantial & 0,014 & 0,021 & & 0,011 & 0,020 & & 0,007 & 0,021 & & 0,014 & 0,021 & & 0,022 & 0,022 & & 0,011 & 0,021 & & 0,013 & 0,021 & & $-0,002$ & 0,024 & & 0,014 & 0,021 & & 0,013 & 0,020 & \\
\hline Variance (3) Cour & 0,234 & $\begin{array}{l}0,021 \\
0,091\end{array}$ & $*$ & $\begin{array}{l}0,241 \\
0,241\end{array}$ & $\begin{array}{l}0,020 \\
0,092\end{array}$ & *** & 0,234 & $\begin{array}{l}0,021 \\
0,091\end{array}$ & $*$ & $\begin{array}{l}0,014 \\
0,245\end{array}$ & $\begin{array}{l}, 021 \\
0,091\end{array}$ & & $\frac{0,232}{0,232}$ & $\begin{array}{l}0,0228 \\
0,088\end{array}$ & *** & 0,238 & $\begin{array}{l}0,021 \\
0,092\end{array}$ & $*$ & 0,231 & $\begin{array}{l}, 021 \\
0,090\end{array}$ & *** & 0,242 & $\frac{0,027}{0,092}$ & *** & 0,206 & $\begin{array}{l}, 021 \\
0,083 \\
\end{array}$ & $*$ & $\begin{array}{l}0,237 \\
0,237\end{array}$ & 0,092 & * \\
\hline (2) $\mathrm{Pe}$ & 0,065 & 0,029 & * & 0,0 & 0,026 & * & 0,06 & 0,028 & * & 0,048 & 0,023 & * & 0,049 & 0,024 & * & 0,063 & 0,028 & $\cdot$ & 0,063 & 0,028 & * & 0,05 & 0,025 & ${ }^{*}$ & 0,065 & 0,029 & * & 0,065 & 0,029 & * \\
\hline (1) Individual & 15,374 & 0,135 & $* * *$ & 15,183 & 0,133 & $* * *$ & 15,547 & 0,136 & $* * *$ & 15,345 & 0,133 & $* * *$ & 15,475 & 0,138 & $* * *$ & 15,547 & 0,136 & $* * *$ & 15,492 & 0,136 & $* * *$ & 15,286 & 0,134 & $* * *$ & 15,622 & 0,137 & $* * *$ & 15,209 & 0,134 & ${ }^{* * * *}$ \\
\hline $\begin{array}{ll}\rho \\
-2 \mathrm{LL}\end{array}$ & $\begin{array}{l}0,019 \\
1450767\end{array}$ & 701 & & $\begin{array}{l}0,019 \\
14215\end{array}$ & & & $\begin{array}{l}0,019 \\
145964\end{array}$ & & & $\begin{array}{l}0,019 \\
176521\end{array}$ & & & $\begin{array}{ll}0,018 \\
1412876\end{array}$ & 670 & & $\begin{array}{l}0,019 \\
167468\end{array}$ & 6812 & & $\begin{array}{l}, 019 \\
0,45098\end{array}$ & & & $\begin{array}{l}0,019 \\
1450255\end{array}$ & 550 & & $\begin{array}{l}, 017 \\
1450211\end{array}$ & & & $\begin{array}{l}, 019 \\
1438016\end{array}$ & & \\
\hline
\end{tabular}


ACCEPTED MANUSCRIPT

Appendix 3_D: Jackknife analysis, the results of Model 4 of Table 3 for women, each time without one country (Part 2)

\begin{tabular}{|c|c|c|c|c|c|c|c|c|c|c|c|c|c|c|c|c|c|c|c|c|c|c|c|c|c|c|c|c|c|c|}
\hline & \multirow{2}{*}{\multicolumn{3}{|c|}{$\begin{array}{l}\mathrm{UK} \\
\mathrm{SE}\end{array}$}} & \multicolumn{3}{|c|}{ Hungary } & \multicolumn{3}{|c|}{ Ireland } & \multicolumn{3}{|c|}{ Netherland } & \multirow{2}{*}{\multicolumn{3}{|c|}{ Norway }} & \multirow{2}{*}{\multicolumn{3}{|c|}{ Poland }} & \multicolumn{3}{|c|}{ Portugal } & \multicolumn{3}{|c|}{ Sweden } & \multirow{2}{*}{\multicolumn{3}{|c|}{$\begin{array}{l}\text { Slovakia } \\
\end{array}$}} & \multicolumn{3}{|c|}{ Slovenia } \\
\hline & & & sig, & b & $\mathrm{SE}$ & sig, & $\mathrm{b}$ & $\mathrm{SE}$ & sig, & $b^{\text {Ne }}$ & SE & sig, & b & & sig, & b & & & b & $\mathrm{SE}$ & sig, & $b^{\mathrm{s}}$ & $\mathrm{SE}$ & sig, & & & sig, & b & SE & sig, \\
\hline Intercept & 6,192 & 0,392 & $* * *$ & 5,962 & 0,350 & $* * *$ & 6,293 & 0,408 & ***** & 6,324 & 0,414 & ***** & 6,289 & 0,407 & $* * *$ & 6,103 & 0,438 & $* * *$ & 6,267 & 0,406 & **** & 6,306 & 0,403 & **** & 6,383 & 0,431 & **** & 6,676 & 0,348 & ***** \\
\hline $\begin{array}{l}\text { Context variables } \\
\text { GDP }\end{array}$ & $-0,054$ & 0,011 & $* * *$ & $-0,040$ & 0,010 & $* * *$ & $-0,051$ & 0,012 & $* * * *$ & $-0,054$ & 0.012 & $* * *$ & $-0,054$ & 0,014 & **** & $-0,052$ & 0.012 & $* *$ & $-0,052$ & 0.012 & *** & $-0,054$ & 0.012 & **** & $-0,054$ & 0,012 & $* * *$ & $-0,064$ & 0.010 & **** \\
\hline Unemployment rate & $\begin{array}{l}-0,034 \\
0,039\end{array}$ & 0,045 & & $\begin{array}{l}-0,040 \\
0,070\end{array}$ & 0,039 & & 0,032 & $\begin{array}{l}0,012 \\
0,047\end{array}$ & & $\begin{array}{l}-0,034 \\
0,030\end{array}$ & $\begin{array}{l}0,012 \\
0,047\end{array}$ & & $\begin{array}{l}-0,029 \\
0,029\end{array}$ & $\begin{array}{l}0,014 \\
0,047\end{array}$ & & $\begin{array}{l}-0,058 \\
0,058\end{array}$ & 0,054 & & $\begin{array}{l}-0,032 \\
0,032\end{array}$ & $\begin{array}{l}0,012 \\
0,046\end{array}$ & & $\begin{array}{l}-0,034 \\
0,028\end{array}$ & 0,046 & & $\begin{array}{r}-0,054 \\
0,017\end{array}$ & 0,052 & & $\begin{array}{l}-0,004 \\
-0,011\end{array}$ & $\begin{array}{l}0,039 \\
0,039\end{array}$ & \\
\hline $\begin{array}{l}\text { Period variables } \\
\text { Period (ref. 2006) }\end{array}$ & & & & & & & & & & & & & & & & & & & & & & & & & & & & & & \\
\hline $\begin{array}{l}\text { Period (ref, } 2 \\
2012\end{array}$ & $-0,625$ & 0,151 & $* * *$ & $-0,567$ & 0,142 & $* * *$ & $-0,562$ & 0,144 & $* * * *$ & $-0,609$ & 0,140 & $* * *$ & $-0,609$ & 0,144 & $* * *$ & $-0,539$ & 0,159 & $* * *$ & $-0,514$ & 0,128 & $* * * *$ & $-0,571 \wedge$ & 0,145 & $* * *$ & $-0,557$ & 0,145 & $* * *$ & $-0,521$ & 0,132 & **** \\
\hline Change in $\mathrm{GDP}^{\mathrm{c}}$ & 0,035 & 0,020 & & 0,026 & 0,018 & & 0,026 & 0,019 & & 0,029 & 0,018 & & 0,040 & 0,022 & & 0,025 & 0,020 & & 0,025 & 0,017 & & 0,028 & 0,019 & & 0,027 & 0,019 & & 0,026 & 0,017 & \\
\hline Change in unemployment $\mathrm{t}^{\mathrm{c}}$ & 0,049 & 0,026 & & 0,044 & 0,026 & & 0,031 & 0,031 & & 0,047 & 0,026 & & 0,050 & 0,026 & & 0,041 & 0,029 & & 0,048 & 0,025 & & 0,045 & 0,027 & & 0,041 & 0,027 & & 0,040 & 0,025 & \\
\hline $\begin{array}{l}\text { Individual variables } \\
\text { Age (ref. 35-49y) }\end{array}$ & & & & & & & & & & & & & , & & & $0,0+1$ & & & & & & & & & $0,0+1$ & & & & & \\
\hline $20-34 y$ & $-0,614$ & 0,067 & $* * *$ & $-0,578$ & 0,066 & $* * *$ & $-0,633$ & 0,067 & $* * *$ & $-0,580$ & 0,067 & $* * *$ & $-0,611$ & 0,067 & **** & $-0,572$ & 0,066 & $* * *$ & $-0,559$ & 0,066 & 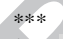 & $-0,632$ & 0,066 & $* * *$ & $-0,553$ & 0,067 & $* * *$ & $-0,618$ & 0,066 & **** \\
\hline $50-64 y$ & 0,167 & 0,062 & $* *$ & 0,124 & 0,062 & * & 0,145 & 0,063 & * & 0,157 & 0,063 & * & 0,150 & 0,063 & * & 0,100 & 0,061 & & 0,126 & 0,062 & & 0,115 & 0,062 & & 0,122 & 0,062 & * & 0,123 & 0,062 & * \\
\hline Employm & & & & & & & & & & & & & & & & & & & & & & & & & & & & & & \\
\hline Non-employed & $-0,548$ & 0,107 & $* * *$ & $-0,582$ & 0,106 & $* * *$ & $-0,535$ & 0,106 & $* * *$ & $-0,584$ & 0,108 & $* * *$ & $-0,533$ & 0,107 & **** & $-0,545$ & 0,111 & 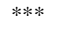 & $-0,555$ & 0,109 & $* * * *$ & $-0,555$ & 0,109 & $* * *$ & $-0,555$ & 0,110 & $* * *$ & $-0,513$ & 0,107 & **** \\
\hline Employed & $-1,071$ & 0,109 & $* * *$ & $-1,123$ & 0,109 & $* * *$ & $-1,081$ & 0,109 & $* * *$ & $-1,100$ & 0,110 & $* * *$ & $-1,049$ & 0,110 & *** & $-1,073$ & 0,113 & $* * *$ & $-1,089$ & 0,112 & **** & $-1,074$ & 0,111 & $* * *$ & $-1,116$ & 0,112 & $* * *$ & $-1,075$ & 0,110 & **** \\
\hline $\begin{array}{l}\text { Type of contract (ref, } \\
\text { x limited }\end{array}$ & 0,453 & 0,099 & $* * *$ & 0,388 & 0,098 & $* * *$ & 0,449 & 0,099 & $* * * *$ & 0,424 & 0,099 & $* * *$ & 0,396 & 0,099 & $* * *$ & 0,470 & 0,099 & ***: & 0,396 & 0,099 & $* * *$ & 0,408 & 0,098 & $* * * *$ & 0,403 & 0,099 & $* * *$ & 0,415 & 0,098 & $* * * *$ \\
\hline $\mathrm{x}$ no contra & 0,048 & 0,161 & & $-0,011$ & 0,153 & & $-0,001$ & 0,170 & & $-0,015$ & 0,156 & & $-0,013$ & 0,157 & & $-0,005$ & 0,153 & & 0,027 & 0,160 & & $-0,014$ & 0,155 & & 0,022 & 0,154 & & 0,012 & 0,154 & \\
\hline $\mathrm{x}$ self-empl & $-0,218$ & 0,106 & * & $-0,255$ & 0,114 & * & $-0,242$ & 0,115 & * & $-0,246$ & 0,116 & * & $-0,264$ & 0,116 & * & $-0,224$ & 0,112 & & $-0,253$ & 0,118 & * & $-0,200$ & 0,106 & & $-0,172$ & 0,117 & & $-0,265$ & 0,115 & * \\
\hline $\begin{array}{l}\text { Work hours (ref, fulltime) } \\
x \text { marginal part time }\end{array}$ & -0.151 & 0.145 & & -0.073 & 0.136 & & -0.119 & 0,139 & & -0.001 & 0.145 & & -0.134 & 0.143 & & -0.129 & 0.138 & & -0.086 & 0.137 & & -0.099 & 0.142 & & -0.112 & 0137 & & -0.105 & 0137 & \\
\hline $\mathrm{x}$ subst & 0,061 & 0,087 & & 0,055 & 0,084 & & 0,027 & 0,085 & & 0,086 & 0,088 & & 0,014 & 0,087 & & 0,057 & 0,085 & & 0,058 & 0,084 & & 0,022 & 0,087 & & 0,056 & 0,085 & & 0,039 & 0,084 & \\
\hline Cross-lev & & & & & & & & & & & & & & & & & & & & & & & & & & & & & & \\
\hline Non-em & 0,001 & 0,021 & & 0,001 & 0,021 & & 0,030 & 0,026 & & 0,002 & 0,021 & & $-0,002$ & 0,021 & & $-0,001$ & 0,022 & & 0,000 & 0,021 & & 0,001 & 0,021 & & 0,001 & 0,021 & & 0,001 & 0,021 & \\
\hline Employ & $-0,014$ & 0,021 & & $-0,010$ & 0,021 & & 0,005 & 0,025 & & $-0,013$ & 0,0 & & $-0,015$ & 0,021 & & $-0,015$ & 0,022 & & $-0,017$ & & & $-0,014$ & 0,021 & & $-0,010$ & 0,021 & & & & \\
\hline $\mathrm{x}$ margin & 0,058 & 0,029 & * & 0,057 & 0,028 & * & 0,0 & 0,026 & * & 0,0 & 00 & & 0,0 & 0,031 & * & 0,070 & 0,033 & * & 0,0 & 0,032 & * & 0,058 & 0,030 & & 0,061 & 0,030 & * & 0,058 & 0,029 & * \\
\hline $\mathrm{x}$ substantia & 0,014 & 0,021 & & 0,013 & 0,021 & & 0,032 & 0,028 & & 0,009 & 0,021 & & 0,013 & 0,021 & & 0,0 & 0,021 & & 0,014 & 0,020 & & 0,014 & 0,021 & & 0,010 & 0,021 & & 0,011 & 0,021 & \\
\hline Variance (3) Cou & 0,207 & 0,083 & * & 0,128 & 0,058 & * & 0,233 & 0,091 & * & 0,240 & 0,092 & *** & 0,244 & 0,093 & ** & 0,221 & 0,087 & * & 0,247 & 0,092 & $* *$ & 0,234 & 0,091 & * & 0,234 & 0,091 & * & 0,134 & 0,057 & * \\
\hline (2) Peri & 0,064 & 0,028 & * & 0,065 & 0,029 & * & 0,066 & 0,029 & * & 0,058 & 0,027 & $*$ & 0,060 & 0,027 & * & 0,065 & $\begin{array}{l}0,029 \\
0,029\end{array}$ & * & 0,046 & 0,022 & $*$ & 0,065 & 0,029 & $*$ & 0,064 & $\begin{array}{l}0,028 \\
0,028\end{array}$ & * & 0,052 & 0,024 & * \\
\hline (1) Individual & 15,284 & 0,135 & $* * *$ & 15,229 & 0,134 & $* * *$ & 15,482 & 0,137 & $* * * *$ & 15,505 & 0,136 & $* * *$ & 15,660 & 0,137 & **** & 15,088 & 0,132 & $* * *$ & 15,247 & 0,135 & $* * *$ & 15,374 & 0,135 & $* * *$ & 15,488 & 0,136 & $* * *$ & 15,486 & 0,135 & $* * *$ \\
\hline-21 & $\begin{array}{ll}0,017 \\
1425844\end{array}$ & & & $\begin{array}{ll}0,013 \\
1448775\end{array}$ & & & $\begin{array}{l}0,019 \\
14484\end{array}$ & & & $\begin{array}{l}, 019 \\
1447824\end{array}$ & & & $\begin{array}{ll}0,019 \\
1463535\end{array}$ & 598 & & 0,019 & & & $\begin{array}{l}0,019 \\
142814\end{array}$ & & & $\begin{array}{l}0,019 \\
1450767\end{array}$ & & & $\begin{array}{l}, 019 \\
1447501\end{array}$ & & & $\begin{array}{ll}0,012 \\
1470495\end{array}$ & & \\
\hline
\end{tabular}


ACCEPTED MANUSCRIPT

Appendix 3_E: Jackknife analysis, the results of Model 3 of Table 4 for men, each time without one country (Part 1)

\begin{tabular}{|c|c|c|c|c|c|c|c|c|c|c|c|c|c|c|c|c|c|c|c|c|c|c|c|c|c|c|c|c|c|c|}
\hline \multirow{2}{*}{ Without } & \multicolumn{3}{|c|}{ Belgium } & \multicolumn{3}{|c|}{$\overline{B u l g a r i a}$} & \multicolumn{3}{|c|}{ Swizz } & \multirow{2}{*}{\multicolumn{3}{|c|}{$\begin{array}{ll}\begin{array}{l}\text { Cyprus } \\
\text { SE }\end{array} \text { sig. } & \end{array}$}} & \multicolumn{3}{|c|}{ Germany } & \multicolumn{3}{|c|}{ Denmark } & \multicolumn{3}{|c|}{ Estonia } & \multicolumn{3}{|c|}{ Spain } & \multicolumn{3}{|c|}{ Finland } & \multicolumn{3}{|c|}{ France } \\
\hline & $\mathrm{b}$ & & sig, & $\mathrm{b}$ & SE & sig, & b & SE & sig, & & & sig, & $\mathrm{b}$ & $\mathrm{SE}$ & sig, & b & SE & sig, & b & $\mathrm{SE}$ & sig, & b & SE & sig, & b & $\mathrm{SE}$ & sig, & b & SE & sig, \\
\hline Intercept & 5,673 & 0,627 & $* * * *$ & 5,666 & 0,651 & $* * * *$ & 5,710 & 0,627 & $* * * *$ & 6,104 & 0,655 & $* * *$ & 5,787 & 0,640 & $* * *$ & 5,654 & 0,628 & & 5,608 & 0,647 & **** & 5,815 & 0,626 & $* * *$ & 5,609 & 0,627 & **** & 5,659 & 0,626 & 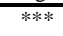 \\
\hline Period variables & & & & & & & & & & & & & & & & & & & & & & & & & & & & & & \\
\hline $\begin{array}{l}\text { Period (ref, 2006) } \\
2012\end{array}$ & $-0,549$ & 0,090 & $* * *$ & $-0,488$ & 0,085 & **** & $-0,537$ & 0,097 & ${ }^{* * * *}$ & $-0,535$ & 0,091 & $* * *$ & $-0,594$ & 0,091 & $* * *$ & $-0,530$ & 0,092 & ${ }^{* * * *}$ & $-0,535$ & 0,093 & $* * *$ & $-0,532$ & 0,089 & $* * *$ & $-0,530$ & 0,094 & $* * *$ & $-0,549$ & 0,092 & ${ }^{* * * *}$ \\
\hline Change in GDP & 0,017 & 0,012 & & 0,014 & 0,011 & & 0,017 & 0,015 & & 0,017 & 0,012 & & 0,021 & 0,011 & & 0,017 & 0,012 & & 0,017 & 0,012 & & 0,015 & 0,012 & & 0,016 & 0,012 & & 0,017 & 0,012 & \\
\hline $\begin{array}{l}\text { Change in unemployment } \\
\text { Individual variables } \\
\text { Age (ref. } 35-49 \mathrm{y} \text { ) }\end{array}$ & 0,040 & 0,013 & $* *$ & 0,038 & 0,012 & $* *$ & 0,038 & 0,014 & $* *$ & 0,038 & 0,014 & $* *$ & 0,051 & 0,014 & $* * *$ & 0,039 & 0,014 & **** & 0,039 & 0,014 & ** & 0,036 & 0,016 & $*$ & 0,039 & 0,014 & $* *$ & 0,040 & 0,013 & ** \\
\hline $20-34 y$ & $-0,527$ & 0,063 & $* * * *$ & $-0,446$ & 0,062 & $* * * *$ & $-0,518$ & 0,064 & $* * *$ & $-0,486$ & 0,063 & $* * *$ & $-0,487$ & 0,064 & $* * *$ & $-0,511$ & 0,063 & $* * *$ & $-0,477$ & 0,063 & $* * *$ & $-0,478$ & 0,063 & $* * *$ & $-0,480$ & 0,064 & $* * *$ & $-0,500$ & 0,063 & **** \\
\hline $50-64 \mathrm{y}$ & $-0,048$ & 0,061 & & $-0,083$ & 0,060 & & $-0,076$ & 0,062 & & $-0,042$ & 0,060 & & $-0,018$ & 0,063 & & $-0,022$ & 0,061 & & $-0,053$ & 0,061 & & & 0,061 & & $-0,051$ & 0,062 & & $-0,054$ & 0,061 & \\
\hline $\begin{array}{l}\text { Employment status } \\
\text { Unemployed (ref, no job seeking) }\end{array}$ & & & & & & & & & & & & & & & & & & & & & & & & & & & & & & \\
\hline $\begin{array}{l}\text { Unemployed (ret, no job seeking) } \\
\text { x seeking for job }\end{array}$ & $\begin{array}{l}2,242 \\
-0,997\end{array}$ & $\begin{array}{l}0,168 \\
0,191\end{array}$ & **** & $\begin{array}{l}2,069 \\
-0,853\end{array}$ & $\begin{array}{l}0,169 \\
0,193\end{array}$ & ***** & $\begin{array}{l}2,156 \\
-0887\end{array}$ & $\begin{array}{l}0,168 \\
0,191\end{array}$ & $* * *$ & $\begin{array}{l}2,1,58 \\
-0,895\end{array}$ & $\begin{array}{l}0,165 \\
0,188\end{array}$ & **** & $\begin{array}{l}2,259 \\
-0,870\end{array}$ & $\begin{array}{l}0,178 \\
0,203\end{array}$ & $* * *$ & $\begin{array}{l}2,166 \\
-0,867\end{array}$ & $\begin{array}{l}0,165 \\
0,189\end{array}$ & ${ }_{* * * *}^{* * *}$ & $\begin{array}{l}2,150 \\
-0,874\end{array}$ & $\begin{array}{l}0,164 \\
0,187\end{array}$ & $* *:$ & $\begin{array}{l}2,250 \\
-1,038\end{array}$ & $\begin{array}{l}0,165 \\
0,188\end{array}$ & $* * *$ & $\begin{array}{l}2,306 \\
-0.981\end{array}$ & 0,172 & $\begin{array}{l}{ }_{* * * *}^{* * *} \\
* * *\end{array}$ & $\begin{array}{l}2,157 \\
-0,878\end{array}$ & 0,166 & ${ }^{* * * *}$ \\
\hline ed (ref, retired) & 0,531 & 0,095 & $* * *$ & 0,468 & 0,094 & $* * *$ & 0,543 & 0,096 & $* * * *$ & 0,498 & 0,094 & $* * *$ & 0,534 & 0,099 & $* * *$ & 0,493 & 0,095 & $* * *$ & 0,465 & 0,094 & $* * *$ & 0,505 & 0,093 & $* * *$ & 0,522 & 0,098 & $* * *$ & 0,593 & 0,096 & **** \\
\hline $\mathrm{x}$ studen & $-0,593$ & 0,151 & $* * *$ & $-0,583$ & 0,148 & $* * *$ & $-0,658$ & 0,152 & $* * *$ & $-0,606$ & 0,149 & $* * *$ & $-0,567$ & 0,160 & $* * *$ & $-0,640$ & 0,152 & $* * *$ & $-0,561$ & 0,150 & $* * *$ & $-0,605$ & 0,149 & $* * *$ & $-0,686$ & 0,155 & $* * * *$ & $-0,721$ & 0,151 & *** \\
\hline $\mathrm{x}$ homework & 0,124 & 0,213 & & 0,253 & 0,213 & & 0,103 & 0,211 & & 0,180 & 0,208 & & 0,217 & 0,220 & & 0,186 & 0,214 & & 0,204 & 0,207 & & 0,162 & 0,205 & & 0,154 & 0,210 & & 0,063 & 0,210 & \\
\hline $\mathrm{x}$ sick/disabled & 3,288 & 0,160 & $* * *$ & 3,329 & 0,155 & $* * *$ & 3,196 & 0,158 & $* * *$ & 3,304 & 0,154 & $* * *$ & 3,230 & 0,163 & $* * *$ & 3,267 & 0,156 & $* * *$ & 3,350 & 0,156 & $* * *$ & 3,260 & 0,154 & $* * *$ & 3,285 & 0,158 & $* * *$ & 3,164 & 0,158 & **** \\
\hline Cross-le & & & & & & & & & & & & & & & & & & & & & & & & & & & & & & \\
\hline unemployed $x$ & $-0,092$ & 0,032 & $* *$ & $-0,084$ & 0,031 & *** & $-0,081$ & 0,032 & ${ }^{* * *}$ & $-0,088$ & 0,032 & $* *$ & $-0,098$ & 0,034 & *** & $-0,085$ & 0,032 & ** & $-0,092$ & 0,031 & $* *$ & $-0,090$ & 0,037 & * & $-0,095$ & 0,032 & ** & $-0,086$ & 0,031 & ** \\
\hline loyment & 0,125 & 0,035 & $* * *$ & 0,115 & 0,034 & **** & 0,107 & 0,035 & ${ }^{* * * *}$ & 0,118 & 0,034 & $* * *$ & 0,113 & 0,037 & *** & 0,114 & 0,035 & $* * *$ & 0,123 & 0,034 & $* * *$ & 0,139 & 0,041 & $* * *$ & 0,121 & 0,035 & $* * *$ & 0,115 & 0,034 & * \\
\hline non-emp & $-0,038$ & 0,021 & & $-0,040$ & 0,021 & & $-0,034$ & 0,021 & & $-0,034$ & 0,021 & & $-0,046$ & 0,023 & $*$ & $-0,036$ & 0,021 & & $-0,043$ & 0,021 & & $-0,014$ & 0,024 & & $-0,036$ & 0,021 & & $-0,038$ & 0,021 & \\
\hline $\mathrm{xs}$ & 0,070 & 0,030 & * & 0,069 & 0,030 & $*$ & 0,069 & 0,030 & * & 0,067 & 0,030 & * & 0,068 & 0,032 & * & 0,065 & 0,030 & $*$ & 0,077 & 0,030 & * & 0,067 & 0,034 & * & 0,072 & 0,030 & * & 0,072 & 0,030 & * \\
\hline & 55 & 0,054 & *** & 0,15 & 0,054 & $* *$ & 0,151 & 0,055 & $* *$ & 0,148 & 0,054 & *** & 0,1 & 0,058 & * & 0,1 & 0,055 & ** & 0,1 & 0,055 & ** & 0,152 & 0,062 & * & 0, & 0,055 & $* *$ & 0,156 & 0,054 & ** \\
\hline $\mathrm{x}$ sick/disab & 0,075 & 0,036 & * & 0,076 & 0,035 & $*$ & 0,080 & 0,036 & $*$ & 0,078 & 0,036 & * & 0,086 & 0,038 & & 0,078 & 0,036 & * & 0,07 & 0,036 & & 0,069 & 0,031 & $*$ & 0,074 & 0,036 & * & 0,079 & 0,035 & * \\
\hline Variance (3) Cou & 0,290 & 0,100 & *** & 0,293 & 0,100 & *** & 0,288 & 0,099 & $* *$ & 0,257 & 0,089 & *** & 0,276 & 0,095 & $* *$ & 0,289 & 0,100 & *** & 0,288 & 0,099 & *** & 0,280 & 0,096 & *** & 0,286 & $\begin{array}{l}0,099 \\
012\end{array}$ & *** & 0,288 & 0,099 & *** \\
\hline $\begin{array}{l}\text { (2) Period } \\
\text { (1) Individual }\end{array}$ & $\begin{array}{l}0,013 \\
12,167\end{array}$ & $\begin{array}{l}0,011 \\
0,113\end{array}$ & $* * *$ & $\begin{array}{l}0,010 \\
11,953\end{array}$ & $\begin{array}{l}0,009 \\
0,111\end{array}$ & $* * *$ & $\begin{array}{l}0,015 \\
12,235\end{array}$ & $\begin{array}{l}0,012 \\
0,114\end{array}$ & $* * *$ & $\begin{array}{l}0,015 \\
12,167\end{array}$ & $\begin{array}{l}0,011 \\
0,112\end{array}$ & $* * *$ & $\begin{array}{l}0,010 \\
12,308\end{array}$ & $\begin{array}{l}0,010 \\
0,117\end{array}$ & $* * *$ & $\begin{array}{l}0,015 \\
12,326\end{array}$ & $\begin{array}{l}0,011 \\
0,114\end{array}$ & $* * *$ & $\begin{array}{l}0,016 \\
12,093\end{array}$ & $\begin{array}{l}0,012 \\
0,112\end{array}$ & $* * *$ & $\begin{array}{l}0,014 \\
12,045\end{array}$ & $\begin{array}{l}0,011 \\
0,112\end{array}$ & $* * *$ & $\begin{array}{l}0,015 \\
12,385\end{array}$ & $\begin{array}{l}0,012 \\
0,116\end{array}$ & $* * * *$ & $\begin{array}{l}0,014 \\
12,111\end{array}$ & $\begin{array}{l}0,011 \\
0,113\end{array}$ & $* * *$ \\
\hline & 0,024 & & & 0,025 & & & 0,024 & & & 0,022 & & & 0,023 & & & 0,024 & & & 0,025 & & & 0,024 & & & 0,024 & & & 0,024 & & \\
\hline & 1234194 & 404 & & 1243061 & & & 122464 & & & 1265502 & & & 119568 & & & 1246296 & & & 123615 & & & 1229615 & & & 1225662 & & & 1229657 & & \\
\hline
\end{tabular}

$\begin{array}{lll}* \mathrm{p}<, 050 & * * \mathrm{p}<, 010 & * * * \mathrm{p}<, 001 ; \mathrm{N} \text { period }(* \text { country) }=38 ; \mathrm{N} \text { country }=19 \\ \text { All models controlled for education, education }{ }^{2} \text {, marital status, income and macro-economic context variables (unemployment rate and GDP) }\end{array}$ 
ACCEPTED MANUSCRIPT

Appendix3_F: Jackknife analysis, the results of model 3 of table 4 for men, each time without one country (Part 2)

\begin{tabular}{|c|c|c|c|c|c|c|c|c|c|c|c|c|c|c|c|c|c|c|c|c|c|c|c|c|c|c|c|c|c|c|}
\hline \multirow{2}{*}{ Without } & \multicolumn{3}{|c|}{$\mathrm{UK}$} & \multicolumn{3}{|c|}{ Hungary } & \multicolumn{3}{|c|}{ Ireland } & \multicolumn{3}{|c|}{ Netherland } & \multicolumn{3}{|c|}{ Norway } & \multicolumn{3}{|c|}{ Poland } & \multicolumn{3}{|c|}{ Portugal } & \multicolumn{3}{|c|}{ Sweden } & \multicolumn{3}{|c|}{ Slovakia } & \multicolumn{3}{|c|}{ Slovenia } \\
\hline & b & SE & sig, & b & $\mathrm{SE}$ & sig, & b & $\mathrm{SE}$ & sig, & b & SE & sig, & b & SE & sig, & b & SE & sig, & b & $\mathrm{SE}$ & sig, & b & SE & sig, & b & SE & sig, & b & $\mathrm{SE}$ & sig, \\
\hline $\begin{array}{l}\text { Intercept } \\
\text { Period variables }\end{array}$ & 5,656 & 0,623 & 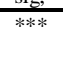 & 4,806 & 0,492 & $* * *$ & 5,612 & 0,630 & $* * *$ & 5,717 & 0,634 & $* * *$ & 5,756 & 0,653 & $* * *$ & 5,250 & 0,618 & $* * *$ & 5,643 & 0,635 & $* * *$ & 5,625 & 0,623 & $* * *$ & 5,921 & 0,622 & **** & 6,054 & 0,623 & **s: \\
\hline $\begin{array}{l}\text { Period (ref, 2006) } \\
2012\end{array}$ & $-0,584$ & 0,093 & $* * *$ & $-0,517$ & 0,091 & $* * *$ & $-0,533$ & 0,093 & $* * *$ & $-0,545$ & 0,092 & $* * *$ & $-0,537$ & 0,096 & $* * *$ & $-0,464$ & 0,098 & $* * *$ & $-0,537$ & 0,093 & $* * *$ & $-0,542$ & 0,092 & $* * *$ & $-0,520$ & 0,092 & $* * *$ & $-0,471$ & 0,072 & **** \\
\hline Change in GDP & 0,023 & 0,012 & & 0,015 & 0,012 & & 0,016 & 0,012 & & 0,017 & 0,012 & & 0,019 & 0,015 & & 0,011 & 0,012 & & 0,017 & 0,012 & & 0,016 & 0,012 & & 0,015 & 0,012 & & 0,014 & 0,010 & \\
\hline $\begin{array}{l}\text { Change in unemployment } \\
\text { Individual variables }\end{array}$ & 0,040 & 0,013 & $* *$ & 0,041 & 0,013 & $* *$ & 0,039 & 0,015 & $* *$ & 0,039 & 0,014 & $* *$ & 0,039 & 0,014 & $* *$ & 0,026 & 0,013 & * & 0,040 & 0,014 & $* *$ & 0,039 & 0,014 & $* *$ & 0,038 & 0,014 & ** & 0,037 & 0,011 & *** \\
\hline Age (ref. 35-49y) & & & & & & & & & & & & & & & & & & & & & & & & & & & & & & \\
\hline $20-34 y$ & $-0,498$ & 0,063 & $* * *$ & $-0,460$ & 0,062 & $* * *$ & $-0,484$ & 0,063 & $* * *$ & $-0,489$ & 0,064 & $* * *$ & $-0,539$ & 0,064 & $* * *$ & $-0,439$ & 0,063 & $* * *$ & $-0,454$ & 0,063 & $* * *$ & $-0,531$ & 0,064 & $* * *$ & $-0,463$ & 0,063 & $* * *$ & $-0,502$ & 0,063 & **** \\
\hline $50-64 y$ & $-0,012$ & 0,061 & & $-0,056$ & 0,060 & & 0,007 & 0,061 & & $-0,008$ & 0,061 & & $-0,035$ & 0,062 & & $-0,083$ & 0,060 & & $-0,044$ & 0,060 & & $-0,021$ & 0,061 & & $-0,044$ & 0,061 & & $-0,049$ & 0,061 & \\
\hline Employn & & & & & & & & & & & & & & & & & & & & & & & & & & & & & & \\
\hline Unemployed ( 1 & 2,163 & 0,166 & $* * *$ & 2,058 & 0,165 & $* * *$ & 2,101 & 0,163 & $* * *$ & 2,072 & 0,168 & $* * *$ & 2,072 & 0,166 & $* * *$ & 2,076 & 0,170 & $* * *$ & 2,211 & 0,167 & Fa & 2,125 & 0,167 & $* * *$ & 2,161 & 0,167 & **** & 2,131 & 0,167 & **** \\
\hline $\mathrm{x}$ seeking for $\mathrm{j}$ & $-0,911$ & 0,189 & $* * * *$ & $-0,734$ & 0,189 & $* * * *$ & $-0,830$ & 0,186 & $* * * *$ & $-0,803$ & 0,191 & $* * *$ & $-0,818$ & 0,189 & $* * *$ & $-0,811$ & 0,195 & $* * *$ & $-0,969$ & 0,191 & $* * *$ & $-0,871$ & 0,191 & $* * *$ & $-0,853$ & 0,192 & **** & $-0,854$ & 0,190 & **** \\
\hline Non-employed (ref, retired) & 0,508 & 0,095 & $* * *$ & 0,457 & 0,095 & $* * *$ & 0,481 & 0,094 & $* * *$ & 0,487 & 0,095 & $* * *$ & 0,461 & 0,095 & $* * *$ & 0,416 & 0,099 & $* * *$ & 0,490 & 0,095 & $* * *$ & 0,482 & 0,094 & $* * *$ & 0,493 & 0,096 & **** & 0,449 & 0,095 & **** \\
\hline $\mathrm{x}$ stud & $-0,604$ & 0,150 & $* * *$ & $-0,534$ & 0,149 & $* * *$ & $-0,598$ & 0,149 & $* * * *$ & $-0,582$ & 0,151 & $* * *$ & $-0,570$ & 0,153 & $* * *$ & $-0,509$ & 0,154 & $* * *$ & $-0,573$ & 0,151 & $* * *$ & $-0,536$ & 0,153 & $* * *$ & $-0,542$ & 0,152 & *** & $-0,560$ & 0,152 & *** \\
\hline $\mathrm{xhom}$ & 0,078 & 0,209 & & 0,174 & 0,208 & & 0,240 & 0,208 & & 0,150 & 0,218 & & 0,188 & 0,212 & & 0,310 & 0,213 & & 0,179 & 0,207 & & 0,182 & 0,209 & & 0,192 & 0,217 & & 0,206 & 0,214 & \\
\hline $\mathrm{x}$ sick/disabled & 3,204 & 0,160 & $* * *$ & 3,303 & 0,156 & $* * *$ & 3,337 & 0,155 & $* * *$ & 3,299 & 0,161 & $* * *$ & 3,344 & 0,159 & $* * *$ & 3,419 & 0,158 & $* * *$ & 3,341 & 0,155 & $* * *$ & 3,259 & 0,157 & $* * *$ & 3,327 & 0,157 & *** & 3,314 & 0,156 & *** \\
\hline & & & & & & & & & & & & & & & & & & & & & & & & & & & & & & \\
\hline ut & 883 & 0,031 & $* *$ & $-0,084$ & 0,031 & $* *$ & $-0,071$ & 0,043 & & $-0,078$ & 0,032 & * & $-0,080$ & 0,032 & * & $-0,072$ & 0,033 & 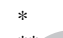 & $-0,094$ & 0,032 & *** & $-0,084$ & 0,032 & $* *$ & $-0,086$ & 0,032 & ** & $-0,089$ & 0,032 & *** \\
\hline & 0,114 & 0,034 & $* *$ & 0,1 & 0,034 & ** & 0,08 & 0,042 & * & 0,1 & 0,035 & ** & 0,1 & 0,035 & $* *$ & 0,1 & 0,0 & & 0,120 & 0,035 & $* * *$ & 0,1 & 0,035 & $* *$ & & 0,035 & *** & 0,117 & 0,035 & **** \\
\hline non-em & $-0,029$ & 0,021 & & $-0,038$ & 0,02 & & $-0,037$ & 0,025 & & $-0,036$ & 0,0 & & -0 & 0,0 & & $-0,031$ & 0,0 & & -0 & 0, & & $-0,035$ & 0,021 & & $-0,036$ & 0,021 & & $-0,035$ & 0,021 & \\
\hline $\mathrm{x}$ stu & 0,060 & 0,030 & * & 0,072 & 0,030 & * & 0,071 & 0,036 & * & 0,070 & 0,030 & * & 0,070 & 0,031 & * & 0,06 & 0,033 & & 0,07 & 0,030 & * & 0,0 & 0,030 & $*$ & 0, & 0,030 & * & 0,066 & 0,030 & * \\
\hline $\mathrm{x}$ ho & 0 , & 0,054 & ** & 0,151 & 0,054 & ** & 0,17 & 0,068 & *** & 0,154 & 0,055 & * & 0,151 & 0,055 & $* *$ & 0,10 & 0,052 & $*$ & 0,15 & 0,054 & $* * *$ & 0,151 & 0,054 & $* *$ & $\begin{array}{l}0,145 \\
0,145\end{array}$ & 0,055 & $* *$ & 0,152 & 0,055 & ** \\
\hline $\mathrm{x}$ sick/d & 0,8 & 0,034 & $*$ & 0,081 & 0,035 & $*$ & 0 , & 0,047 & $*$ & 0,076 & 0,036 & * & 0,068 & 0,035 & & 0,034 & 0,017 & $*$ & 0,080 & 0,035 & * & 0,076 & 0,036 & & 0,069 & 0,035 & & 0,074 & 0,036 & * \\
\hline Variance (3) C & 0,282 & 0,097 & *** & 0,135 & 0,050 & $* *$ & 0,288 & 0,100 & *** & 0,290 & 0,100 & *** & 0,287 & 0,099 & *** & 0,241 & 0,084 & *** & 0,288 & 0,100 & $* *$ & 0,280 & 0,097 & $* *$ & 0,261 & 0,091 & *** & 0,251 & 0,085 & *** \\
\hline (2) Perio & 0,012 & 0,010 & & 0,014 & 0,011 & & 0,015 & 0,012 & & 0,014 & 0,011 & & 0,015 & 0,012 & & 0,013 & 0,011 & & 0,016 & 0,012 & & 0,015 & 0,012 & & 0,014 & 0,011 & & 0,002 & 0,007 & \\
\hline (1) Individual & 12,061 & 0,113 & $* * *$ & 11,886 & 0,110 & $* * *$ & 12,012 & 0,112 & $* * *$ & 12,254 & 0,114 & $* * *$ & 12,378 & 0,115 & $* * *$ & 11,975 & 0,112 & **** & 12,092 & 0,112 & $* * *$ & 12,259 & 0,114 & $* * *$ & 12,135 & 0,113 & $* * *$ & 12,247 & 0,113 & *** \\
\hline $\begin{array}{l}\rho \\
-2 L L\end{array}$ & $\begin{array}{r}0,024 \\
122 \\
\end{array}$ & 42 & & $\begin{array}{r}0,012 \\
12 \\
\end{array}$ & 2205 & & $\begin{array}{r}0,025 \\
12 \\
\end{array}$ & 2175480 & & $\begin{array}{r}024 \\
12 \\
\end{array}$ & 3471160 & & 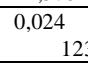 & 23383719 & & & 28 & & $\begin{array}{l}25 \\
12 \\
\end{array}$ & 0256 & & $\begin{array}{c}0,023 \\
122\end{array}$ & 68 & & $\begin{array}{r}0,022 \\
12 \\
\end{array}$ & 714149 & & 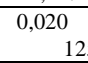 & 972 & \\
\hline
\end{tabular}


ACCEPTED MANUSCRIPT

Appendix 3_G: Jackknife analysis, the results of Model 3 of Table 4 for women, each time without one country (Part 1)

\begin{tabular}{|c|c|c|c|c|c|c|c|c|c|c|c|c|c|c|c|c|c|c|c|c|c|c|c|c|c|c|c|c|c|c|}
\hline \multirow{2}{*}{ Without } & \multicolumn{3}{|c|}{ Belgium } & \multicolumn{3}{|c|}{ Bulgaria } & \multicolumn{3}{|c|}{ Swizz } & \multirow{2}{*}{\multicolumn{3}{|c|}{$\begin{array}{ll}\begin{array}{l}\text { Cyprus } \\
\text { SE }\end{array} \text { sig. } & \end{array}$}} & \multicolumn{3}{|c|}{ Germany } & \multicolumn{3}{|c|}{ Denmark } & \multicolumn{3}{|c|}{ Estonia } & \multicolumn{3}{|c|}{ Spain } & \multicolumn{3}{|c|}{ Finland } & \multicolumn{3}{|c|}{ France } \\
\hline & $\mathrm{b}$ & SE & sig, & b & SE & sig, & $\mathrm{b}$ & SE & sig, & & & sig, & $\mathrm{b}$ & SE & sig, & b & SE & sig, & b & SE & sig, & b & SE & sig, & b & SE & sig, & b & SE & sig, \\
\hline Intercept & 6,588 & 0,581 & ***** & 6,525 & 0,604 & ***** & 6,526 & 0,578 & $* * * *$ & 6,704 & 0,639 & **** & 6,707 & 0,589 & $* * * *$ & 6,551 & 0,582 & $* * *$ & 6,767 & 0,618 & * & 6,664 & 0,591 & $* * *$ & 6,462 & 0,555 & $* * *$ & 6,564 & $\overline{0,583}$ & $* * * *$ \\
\hline \multicolumn{31}{|l|}{$\begin{array}{l}\text { Period variables } \\
\text { Period (ref, 2006) }\end{array}$} \\
\hline 2012 & $-0,579$ & 0,137 & $* * *$ & $-0,549$ & 0,132 & $* * *$ & $-0,539$ & 0,141 & $* * *$ & $-0,626$ & 0,124 & $* * *$ & $-0,679$ & 0,132 & $* * *$ & $-0,589$ & 0,133 & $* * *$ & $-0,574$ & 0,132 & $* * *$ & $-0,571$ & 0,128 & $* * *$ & $-0,579$ & 0,137 & $* * *$ & $-0,588$ & 0,138 & **** \\
\hline Change in GDP & 0,028 & 0,019 & & 0,025 & 0,018 & & 0,016 & 0,024 & & 0,030 & 0,017 & & 0,025 & 0,017 & & 0,026 & 0,019 & & 0,029 & 0,019 & & 0,023 & 0,018 & & 0,025 & 0,019 & & 0,028 & 0,019 & \\
\hline Change in unemployment & 0,037 & 0,020 & & 0,038 & 0,019 & * & 0,034 & 0,020 & & 0,036 & 0,019 & & 0,054 & 0,020 & ** & 0,037 & 0,020 & & 0,017 & 0,024 & & 0,016 & 0,023 & & 0,038 & 0,020 & & 0,039 & 0,019 & \\
\hline \multicolumn{31}{|l|}{$\begin{array}{l}\text { Individual variables } \\
\text { Age (ref. } 35-49 \mathrm{y})\end{array}$} \\
\hline $20-34 y$ & $-0,428$ & 0,066 & $* * * *$ & $-0,381$ & 0,066 & $* * *$ & $-0,437$ & 0,067 & $* * *$ & $-0,388$ & 0,066 & $* * * *$ & $-0,411$ & 0,067 & $* * *$ & $-0,389$ & 0,066 & $* * *$ & $-0,395$ & 0,068 & & $-0,380$ & 0,066 & $* * *$ & $-0,408$ & 0,067 & $* * *$ & $-0,377$ & 0,066 & $* * *$ \\
\hline $50-64 y$ & 0,041 & 0,064 & & 0,025 & 0,064 & & 0,047 & 0,064 & & 0,066 & 0,063 & & 0,068 & 0,065 & & 0,064 & 0,064 & & 0,065 & 0,066 & & 0,065 & 0,064 & & 0,071 & 0,064 & & 0,072 & 0,064 & \\
\hline \multicolumn{31}{|l|}{ Employment status } \\
\hline Unemplo & 238 & 0,184 & $* * * *$ & 1,270 & 0,178 & $* * *$ & 1,218 & 0,176 & $* * *$ & 1,183 & 0,174 & $* * *$ & 1,296 & 0,181 & $* * *$ & 1,128 & 0,175 & $* * * *$ & 1,29 & 0,17 & & 1,224 & 0,174 & $* * *$ & 1,246 & 0,182 & **** & 1,202 & 0,177 & **** \\
\hline $\mathrm{x} \mathrm{seel}$ & $-0,278$ & 0,213 & & $-0,328$ & 0,209 & & $-0,247$ & 0,205 & & $-0,203$ & 0,204 & & $-0,351$ & 0,213 & & $-0,145$ & 0,205 & & $-0,267$ & 0,20 & & $-0,197$ & 0,203 & & $-0,248$ & 0,212 & & $-0,200$ & 0,208 & \\
\hline Non-employed (ref, retired) & 0,477 & 0,100 & $* * *$ & 0,413 & 0,101 & $* * *$ & 0,476 & 0,101 & $* * *$ & 0,443 & 0,099 & $* * *$ & 0,478 & 0,104 & $* * *$ & 0,437 & 0,101 & $* * *$ & 0,437 & 0,102 & $* * *$ & 0,453 & 0,099 & $* * *$ & 0,392 & 0,102 & $* * *$ & 0,457 & 0,101 & $* * *$ \\
\hline $\mathrm{x}$ student & $-0,788$ & 0,158 & $* * *$ & $-0,730$ & 0,156 & $* * *$ & $-0,795$ & 0,158 & $* * *$ & $-0,776$ & 0,155 & $* * *$ & $-0,768$ & 0,163 & $* * *$ & $-0,855$ & 0,159 & $* * *$ & $-0,724$ & 0,161 & $* * *$ & $-0,777$ & 0,155 & $* * *$ & $-0,744$ & 0,161 & $* * *$ & $-0,762$ & 0,157 & $* * *$ \\
\hline $\mathrm{x}$ homework & $-0,319$ & 0,113 & $* *$ & $-0,261$ & 0,114 & * & $-0,275$ & 0,113 & $*$ & $-0,264$ & 0,112 & $*$ & $-0,247$ & 0,117 & $*$ & $-0,273$ & 0,113 & $*$ & $-0,219$ & 0,110 & $*$ & $-0,272$ & 0,111 & * & $-0,193$ & 0,114 & & $-0,264$ & 0,113 & * \\
\hline $\mathrm{x}$ sick/disabled & 3,279 & 0,171 & $* * *$ & 3,336 & 0,168 & $* * *$ & 3,294 & 0,168 & **** & 3,343 & 0,166 & $* * *$ & 3,210 & 0,176 & $* * *$ & 3,311 & 0,168 & $* *$ & 3,442 & 0,171 & $* * *$ & 3,332 & 0,166 & $* * *$ & 3,420 & 0,170 & *** & 3,304 & 0,170 & $* * *$ \\
\hline \multicolumn{31}{|l|}{ Cross-level interactions } \\
\hline unemployed $x$ change in $u$ & $-0,002$ & 0,036 & & $-0,003$ & 0,036 & & 0,001 & 0,036 & & $-0,002$ & 0,036 & & $-0,014$ & 0,037 & & $-0,003$ & 0,036 & & 0,045 & 0,045 & & 0,032 & 0,045 & & $-0,002$ & 0,037 & & 0,002 & 0,036 & \\
\hline $\mathrm{x}$ seeking for job $\mathrm{x}$ change in unen & 0,010 & 0,041 & & 0,010 & 0,041 & & 0,007 & 0,041 & & 0,009 & 0,041 & & 0,026 & 0,042 & & 0,008 & 0,041 & & $-0,011$ & 0,051 & & $-0,004$ & 0,051 & & 0,007 & 0,041 & & 0,004 & 0,041 & \\
\hline non-employed $x$ ch & $-0,037$ & 0,026 & & $-0,041$ & 0,026 & & $-0,037$ & 0,027 & & $-0,033$ & 0,026 & & $-0,055$ & 0,029 & & $-0,039$ & 0,027 & & $-0,056$ & 0,029 & & $-0,048$ & 0,028 & & $-0,035$ & 0,027 & & $-0,036$ & 0,026 & \\
\hline $\mathrm{x}$ student $\mathrm{x}$ change in unemployment & 0,026 & 0,036 & & 0,030 & 0,035 & & 0,029 & 0,036 & & 0,026 & 0,036 & & 0,042 & 0,038 & & 0,028 & 0,036 & & 0,081 & 0,044 & & 0,055 & 0,041 & & 0,027 & 0,036 & & 0,025 & 0,035 & \\
\hline $\mathrm{x}$ homeworl & 0,081 & 0,028 & ** & 0,083 & 0,028 & ** & 0,079 & 0,028 & ** & 0,074 & 0,028 & ** & 0,090 & 0,030 & ** & 0,081 & 0,028 & ** & 0,104 & 0,031 & *** & 0,094 & 0,030 & ** & 0,076 & 0,029 & ** & 0,078 & 0,028 & ** \\
\hline $\mathrm{x}$ sick/disa & $-0,057$ & 0,049 & & $-0,057$ & 0,048 & & $-0,060$ & 0,049 & & $-0,063$ & 0,048 & & 0,002 & 0,052 & & $-0,056$ & 0,049 & & $-0,027$ & 0,057 & & $-0,070$ & 0,055 & & $-0,067$ & 0,049 & & $-0,060$ & 0,048 & \\
\hline Variance (3) Coun & 0,216 & 0,084 & *** & 0,220 & 0,084 & *** & 0,213 & 0,082 & *** & 0,223 & 0,084 & *** & 0,207 & 0,079 & * & 0,217 & $\begin{array}{l}0,084 \\
005\end{array}$ & $*$ & 0,226 & 0,088 & *** & 0,222 & 0,084 & *** & 0,188 & 0,075 & * & 0,216 & 0,084 & * \\
\hline (2) $\mathrm{Per}$ & 0,056 & 0,025 & ${ }^{*}$ & 0,050 & 0,024 & $*$ & 0,055 & 0,025 & ${ }^{*}$ & 0,043 & 0,021 & $*$ & 0,044 & 0,022 & $* * *$ & 0,054 & 0,025 & $*$ & 0,051 & 0,025 & $*$ & 0,048 & 0,023 & $*$ & 0,057 & 0,026 & $*$ & 0,057 & 0,026 & ${ }^{*}$ \\
\hline (1) Individual & 15,047 & 0,132 & $* * *$ & 14,844 & 0,130 & $* * *$ & 15,213 & 0,133 & $* * *$ & 15,000 & 0,130 & $* * *$ & 15,156 & 0,135 & $* * *$ & 15,204 & 0,133 & $* * *$ & 15,043 & 0,136 & $* * *$ & 14,944 & 0,131 & $* * *$ & 15,272 & 0,134 & $* * *$ & 14,883 & 0,131 & $* * *$ \\
\hline & 0,018 & & & 0,018 & & & 0,017 & & & 0,017 & & & 0,016 & & & 0,018 & & & 0,018 & & & 0,018 & & & 0,016 & & & 0,018 & & \\
\hline & 1445143 & & & 143627 & & & 145393 & & & 14704 & & & 140757 & & & 146157. & & & 13572 & & & 14443 & & & 14443 & & & 143238 & & \\
\hline
\end{tabular}

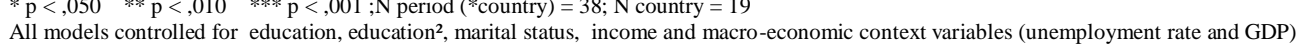


ACGEPTED MANUSCRIPT

Appendix 3_H: Jackknife analysis, the results of Model 3 of Table 4 for women, each time without one country (Part 2)

\begin{tabular}{|c|c|c|c|c|c|c|c|c|c|c|c|c|c|c|c|c|c|c|c|c|c|c|c|c|c|c|c|c|c|c|}
\hline \multirow{2}{*}{ Without } & \multirow{2}{*}{\multicolumn{3}{|c|}{$\begin{array}{l}\mathrm{UK} \\
\mathrm{SE}\end{array}$}} & \multicolumn{3}{|c|}{ Hungary } & \multicolumn{3}{|c|}{ Ireland } & \multicolumn{3}{|c|}{ Netherland } & \multicolumn{3}{|c|}{ Norway } & \multicolumn{3}{|c|}{ Poland } & \multicolumn{3}{|c|}{$\begin{array}{l}\text { Portugal } \\
\end{array}$} & \multicolumn{3}{|c|}{ Sweden } & \multicolumn{3}{|c|}{ Slovakia } & \multicolumn{3}{|c|}{ Slovenia } \\
\hline & & & sig, & b & $\mathrm{SE}$ & sig, & b & SE & sig, & b & $\mathrm{SE}$ & sig, & b & $\mathrm{SE}$ & sig, & b & SE & sig, & b & SE & sig, & b & SE & sig, & b & $\mathrm{SE}$ & sig, & b & SE & sig, \\
\hline Intercept & 6,505 & 0,561 & $* * *$ & 5,865 & 0,505 & $* * * *$ & 6,485 & 0,586 & $* * *$ & 6,577 & 0,588 & $* * *$ & 6,589 & 0,608 & **** & 6,361 & 0,609 & **** & 6,501 & 0,587 & **** & 6,506 & 0,578 & **** & 6,620 & 0,601 & **** & 7,148 & 0,506 & **** \\
\hline \multirow{2}{*}{\multicolumn{31}{|c|}{$\begin{array}{l}\text { Period variables } \\
\text { Period (ref, 2006) }\end{array}$}} \\
\hline & & & & & & & & & & & & & & & & & & & & & & & & & & & & & & \\
\hline & $-0,648$ & 0,143 & $* * *$ & $-0,583$ & 0,135 & **** & $-0,574$ & 0,137 & $* * *$ & $-0,613$ & 0,135 & $* * * *$ & $-0,626$ & 0,135 & $* * *$ & $-0,562$ & 0,152 & $* * *$ & $-0,531$ & 0,121 & $* * *$ & $-0,589$ & 0,135 & **** & $-0,572$ & 0,138 & $* * *$ & $-0,538$ & 0,124 & **** \\
\hline Change in GDP & 0,035 & 0,020 & & 0,026 & 0,018 & & 0,026 & 0,019 & & 0,029 & 0,018 & & 0,030 & 0,022 & & 0,025 & 0,020 & & 0,025 & 0,017 & & 0,028 & 0,019 & & 0,027 & 0,019 & & 0,024 & 0,017 & \\
\hline Change in unemployment & 0,041 & 0,020 & * & 0,041 & 0,020 & * & 0,041 & 0,023 & & 0,040 & 0,020 & * & 0,042 & 0,020 & * & 0,032 & 0,023 & & 0,038 & 0,018 & * & 0,038 & 0,020 & & 0,037 & 0,020 & & 0,033 & 0,018 & \\
\hline \multirow{2}{*}{\multicolumn{31}{|c|}{$\begin{array}{l}\text { Individual variables } \\
\text { Age (ref. } 35-49 \mathrm{y} \text { ) }\end{array}$}} \\
\hline & & & & & & & & & & & & & & & & & & & & & & & & & & & & & & \\
\hline $20-34 y$ & $-0,418$ & 0,067 & **** & $-0,377$ & 0,066 & ***** & $-0,417$ & 0,067 & $* * *$ & $-0,384$ & 0,067 & ${ }^{* * * *}$ & $-0,408$ & 0,067 & **** & $-0,372$ & 0,066 & **** & $-0,353$ & 0,066 & ${ }^{* * * *}$ & $-0,389$ & 0,066 & $* * *$ & $-0,350$ & 0,067 & **** & 0,410 & 0,066 & ${ }^{* * * * *}$ \\
\hline \multirow{2}{*}{\multicolumn{31}{|c|}{ Employ }} \\
\hline & & & & & & & & & & & & & & & & & & & & & & & & & & & & & & \\
\hline $\begin{array}{l}\text { Unemploy } \\
\mathrm{x} \text { seeking } \mathrm{f}\end{array}$ & $\begin{array}{l}1,002 \\
-0,054\end{array}$ & 0,206 & & $\begin{array}{l}1,201 \\
-0,200\end{array}$ & 0,205 & & $\begin{array}{l}1,199 \\
-0,212\end{array}$ & $\begin{array}{l}0,173 \\
0,204\end{array}$ & & $\begin{array}{l}1,1 / 6 \\
-0,177\end{array}$ & $\begin{array}{l}0,279 \\
0,208\end{array}$ & & $\begin{array}{l}1,156 \\
-0,174\end{array}$ & 206 & 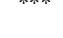 & $\begin{array}{l}1,216 \\
-0,253\end{array}-10$ & 0,1844 & 策 & $\begin{array}{l}1,269 \\
-0,307\end{array}$ & $0,0,211$ & & $\begin{array}{l}1,1,14 \\
-0,118\end{array}$ & 0,206 & & $\begin{array}{l}1,166 \\
-0,128\end{array}$ & $\begin{array}{l}0,1 / 9 \\
0,210\end{array}$ & 型 & $\begin{array}{l}1,196 \\
-0215\end{array}$ & 0,171 & (3) \\
\hline Non-employed (ref, retired) & 0,504 & 0,102 & $* * *$ & 0,430 & 0,101 & $* * *$ & 0,466 & 0,100 & $* * *$ & 0,433 & 0,100 & $* * *$ & 0,435 & 0,100 & $* * *$ & 0,316 & 0,105 & ** & 0,422 & 0,101 & **: & 0,454 & 0,100 & **** & 0,423 & 0,104 & **** & 0,501 & 0,102 & **** \\
\hline $\mathrm{x}$ studen & $-0,820$ & 0,158 & $* * *$ & $-0,743$ & 0,157 & $* * *$ & $-0,780$ & 0,157 & $* * *$ & $-0,791$ & 0,158 & $* * *$ & $-0,753$ & 0,160 & $* * *$ & $-0,584$ & 0,161 & $* * *$ & $-0,727$ & 0,158 & ** & $-0,873$ & 0,159 & **** & $-0,719$ & 0,159 & **** & $-0,848$ & 0,159 & **** \\
\hline $\mathrm{x}$ homework & $-0,336$ & 0,114 & *** & $-0,228$ & 0,113 & . & $-0,263$ & 0,113 & * & $-0,247$ & 0,114 & * & $-0,256$ & 0,113 & * & $-0,235$ & 0,117 & * & $-0,267$ & 0,114 & & $-0,264$ & 0,112 & * & $-0,221$ & 0,110 & * & $-0,298$ & 0,114 & ** \\
\hline $\mathrm{x}$ sick/disabled & 3,146 & 0,173 & $* * *$ & 3,381 & 0,169 & $* * * *$ & 3,288 & 0,167 & $* * *$ & 3,329 & 0,176 & $* * *$ & 3,449 & 0,171 & $* * *$ & 3,415 & 0,169 & $* * *$ & 3,408 & 0,168 & *** & 3,477 & 0,173 & ***** & 3,430 & 0,170 & **** & 3,299 & 0,168 & *** \\
\hline \multirow{2}{*}{\multicolumn{31}{|c|}{ 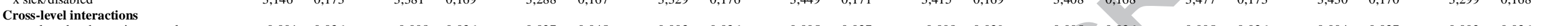 }} \\
\hline $\begin{array}{l}\text { unemp } \\
\text { unst }\end{array}$ & $-0,001$ & 0,036 & & $-0,008$ & 0,036 & & 0,027 & 0,045 & & 0,003 & 0,036 & & 0,005 & 0,037 & & $-0,008$ & 0,039 & & 0,005 & 0,036 & & 0,005 & 0,036 & & 0,004 & 0,037 & & 0,002 & 0,036 & \\
\hline & 0,008 & 0,041 & & 0,013 & 0,041 & & $-0,051$ & 0,0 & & 0,002 & 0,0 & & 0,0 & 0,041 & & 0,01 & 0,04 & & 0,004 & 0,041 & & $-0,002$ & 0,041 & & $-0,003$ & 0,041 & & 0,004 & 0,041 & \\
\hline & $-0,020$ & 0,027 & & $-0,045$ & 0,027 & & $-0,007$ & 0,0 & & $-0,036$ & 0,0 & & $-0,039$ & 0,027 & & $-0,0$ & 0,0 & & $-0,038$ & 0,027 & & $-0,036$ & & & $-0,031$ & 0,027 & & $-0,028$ & 0,027 & \\
\hline & 0,011 & 0,036 & & 0,034 & 0,036 & & $-0,026$ & 0,043 & & 0,029 & 0,036 & & 0,02 & 0,036 & & $-0,024$ & 0,0 & & 0,0 & 0,036 & & 0,0 & & & 0,014 & 0,036 & & 0,018 & 0,036 & \\
\hline $\mathrm{x}$ home & 0,060 & 0,029 & * & 0,085 & 0,029 & ** & 0,079 & 0,035 & * & 0,079 & 0,028 & ** & 0,081 & 0,029 & $* *$ & 0,04 & 0,033 & & 0,08 & 0,029 & *** & 0,078 & 0,028 & ***** & 0,072 & 0,029 & * & 0,071 & 0,028 & * \\
\hline $\mathrm{x}$ sick/disable & $-0,090$ & 0,049 & & $-0,065$ & 0,049 & & $-0,114$ & 0,060 & & $-0,060$ & 0,049 & & $-0,078$ & 0,049 & & $-0,076$ & 0,051 & & $-0,051$ & 0,049 & & $-0,073$ & 0,049 & & $-0,072$ & 0,049 & & $-0,066$ & 0,049 & \\
\hline Variance (3) $\mathrm{C}$ & 0,1 & 0,077 & *** & 0,171 & 0,052 & $* *$ & 0, & 0,083 & * & 0,2 & 0,084 & $* *$ & 0,2 & 0,085 & ** & 0,20 & 0, & * & 0,2 & 0,084 & *** & $\overline{0,2}$ & 0,082 & r & & 0,083 & * & 0,159 & 0,054 & *** \\
\hline (2) Per & 0,055 & 0,025 & * & 0,057 & 0,026 & * & 0,058 & 0,026 & * & 0,053 & 0,025 & * & 0,051 & 0,024 & * & 0,058 & 0,026 & $*$ & 0,039 & 0,019 & $*$ & 0,056 & 0,026 & * & 0,057 & 0,026 & * & 0,058 & 0,022 & * \\
\hline (1) Individual & 14,988 & 0,133 & $* * *$ & 14,891 & 0,131 & $* * * *$ & 15,142 & 0,134 & $* * *$ & 15,198 & 0,134 & $* * *$ & 15,312 & 0,134 & $* * *$ & 14,751 & 0,129 & $* * *$ & 14,889 & 0,132 & $* * *$ & 15,088 & 0,132 & ***** & 15,131 & 0,133 & **** & 15,141 & 0,132 & **** \\
\hline & & & & 0,01 & & & & & & & & & & & & & & & & & & & & & & & & & & \\
\hline$-2 \mathrm{I}$ & 14208 & & & 14428 & & & 14291 & & & 14426 & & & 1457 & & & & & & 142 & & & 144 & & & 44 & & & 14645 & & \\
\hline
\end{tabular}

${ }^{*} \mathrm{p}<, 050{ }^{* *} \mathrm{p}<, 010$
All models controlled for education, education ${ }^{2}$, marital status, income and macro-economic context variables (unemployment rate and GDP) 


\section{RESEARCH HIGHLIGHTS}

-There is an increase in depression only in countries strongly affected by the economic crisis -The economic crisis affects the mental health of the employed as well as the unemployed.

-The impact of the economic crisis on depression is stronger for men and those 35-49 years of age.

-The recession has changed the relationship between part-time work and depression.

-Men looking for work are more depressed in countries hardest hit by the crisis. 